\title{
Characteristics of meiofauna in extreme marine ecosystems: a review
}

\author{
Daniela Zeppilli $^{1}$ (D) Daniel Leduc ${ }^{2}$ - Christophe Fontanier ${ }^{3}$ - Diego Fontaneto ${ }^{4}$. \\ Sandra Fuchs ${ }^{1}$ • Andrew J. Gooday ${ }^{5}$ - Aurélie Goineau ${ }^{5}$ - Jeroen Ingels ${ }^{6}$ • \\ Viatcheslav N. Ivanenko ${ }^{7}$ • Reinhardt Møbjerg Kristensen ${ }^{8} \cdot$ Ricardo Cardoso Neves $^{9}$. \\ Nuria Sanchez $^{1}$ - Roberto Sandulli ${ }^{10}$ - Jozée Sarrazin ${ }^{1}$ - Martin V. Sørensen ${ }^{8}$. \\ Aurélie Tasiemski ${ }^{11}$ - Ann Vanreusel ${ }^{12}$ - Marine Autret ${ }^{13}$ - Louis Bourdonnay ${ }^{13}$. \\ Marion Claireaux ${ }^{13}$ - Valérie Coquillé ${ }^{13}$ - Lisa De Wever ${ }^{13}$ - Durand Rachel $^{13}$. \\ James Marchant $^{13}$ • Lola Toomey ${ }^{13}$ - David Fernandes ${ }^{14}$
}

Received: 28 April 2017 /Revised: 16 October 2017 / Accepted: 23 October 2017 / Published online: 17 November 2017

(C) The Author(s) 2017. This article is an open access publication

\begin{abstract}
Extreme marine environments cover more than $50 \%$ of the Earth's surface and offer many opportunities for investigating the biological responses and adaptations of organisms to stressful life conditions. Extreme marine environments are sometimes associated with ephemeral and unstable ecosystems, but can host abundant, often endemic and welladapted meiofaunal species. In this review, we present an integrated view of the biodiversity, ecology and physiological responses of marine meiofauna inhabiting several extreme marine environments (mangroves, submarine caves, Polar ecosystems, hypersaline areas, hypoxic/anoxic environments, hydrothermal vents, cold seeps, carcasses/sunken woods,
\end{abstract}

Communicated by S. Gollner

Daniela Zeppilli

Daniela.Zeppilli@ifremer.fr

1 IFREMER, Centre Brest, REM/EEP/LEP, ZI de la pointe du diable, CS10070, 29280 Plouzané, France

2 National Institute of Water and Atmospheric Research, Private Bag 14-901, Wellington 6021, New Zealand

3 IFREMER, Centre Brest, REM/GM/LES, ZI de la pointe du diable, CS10070, 29280 Plouzané, France

4 National Research Council, Institute of Ecosystem Study, Largo Tonolli 50, 28922 Verbania Pallanza, Italy

5 National Oceanography Centre, University of Southampton Waterfront Campus, European Way, Southampton S014 3ZH, UK

6 Florida State University Coastal and Marine Laboratory, 3618 Coastal Highway 98, St. Teresa, FL 32327, USA

7 Department of Invertebrate Zoology, Biological Faculty, Lomonosov Moscow State University, Moscow, Russia deep-sea canyons, deep hypersaline anoxic basins [DHABs] and hadal zones). Foraminiferans, nematodes and copepods are abundant in almost all of these habitats and are dominant in deep-sea ecosystems. The presence and dominance of some other taxa that are normally less common may be typical of certain extreme conditions. Kinorhynchs are particularly well adapted to cold seeps and other environments that experience drastic changes in salinity, rotifers are well represented in polar ecosystems and loriciferans seem to be the only metazoan able to survive multiple stressors in DHABs. As well as natural processes, human activities may generate stressful conditions, including deoxygenation, acidification and rises in

8 Natural History Museum of Denmark, University of Copenhagen, Universitetsparken 15, 2100 Copenhagen Ø, Denmark

9 Biozentrum, University of Basel, Klingelbergstrasse 50, 4056 Basel, Switzerland

10 Di.S.T., University of Naples "Parthenope", Centro Direzionale Isola C4, 80143 Napoli, Italy

11 CNRS, UMR 8198 - Evo-Eco-Paleo, SPICI Group, Université de Lille, 59000 Lille, France

12 Department of Biology, Marine Biology Section, Ghent University, Krijgslaan 281, S8, 9000 Ghent, Belgium

13 Institut Universitaire Européen de la Mer, Laboratoire des Sciences de l'Environnement Marin (UMR6539 CNRS/IRD/UBO), Université de Brest, rue Dumont d'Urville, 29280 Plouzané, France

14 IFREMER, Centre Brest, BLP, Institut Carnot Ifremer-EDROME, ZI de la pointe du diable, CS10070, 29280 Plouzané, France 
temperature. The behaviour and physiology of different meiofaunal taxa, such as some foraminiferans, nematode and copepod species, can provide vital information on how organisms may respond to these challenges and can provide a warning signal of anthropogenic impacts. From an evolutionary perspective, the discovery of new meiofauna taxa from extreme environments very often sheds light on phylogenetic relationships, while understanding how meiofaunal organisms are able to survive or even flourish in these conditions can explain evolutionary pathways. Finally, there are multiple potential economic benefits to be gained from ecological, biological, physiological and evolutionary studies of meiofauna in extreme environments. Despite all the advantages offered by meiofauna studies from extreme environments, there is still an urgent need to foster meiofauna research in terms of composition, ecology, biology and physiology focusing on extreme environments.

Keywords Extreme environments $\cdot$ Meiofauna $\cdot$ Mangroves $\cdot$ Submarine caves $\cdot$ Polar ecosystems $\cdot$ Melting ice

Hypersaline areas $\cdot$ Anoxic and hypoxic zones $\cdot$ Hydrothermal vents · Cold seeps $\cdot$ Carcasses and sunken woods · Deep sea . Submarine canyons $\cdot$ Deep hypersaline anoxic basins (DHABs) $\cdot$ Hadal zones

\section{Introduction}

Natural environments are considered extreme when one or more environmental parameters show values permanently close to the lower or upper limits for life (CAREX 2011). Terrestrial, marine, polar and deep-sea ecosystems include both stable and unstable environments. In stable environments (e.g. polar ecosystems), well-adapted organisms live near the limits of their physiological potential for long periods. In less stable environments (e.g. hydrothermal vents), organisms intermittently experience the limits of their physiological potential and develop diverse strategies to survive these stochastic variations (CAREX 2011). Other environments can be considered extreme in the sense that organisms are exposed to environmental variability to such an extent that the communities are in constant ecological flux, limiting the establishment of mature communities (Hoffmann and Parsons 1997). Submarine canyons and mangrove systems, which are characterised by constant variations of their hydrological and biogeochemical conditions, belong in this category.

Extreme natural environments offer unique opportunities for investigating the biological response and adaptation of organisms to stressful life conditions (Rothschild and Mancinelli 2001). In addition, examples of putative early Earth environments can be found in some of the extreme habitats of the modern Earth. The discovery of extremophile species has even made the search for life outside Earth more plausible and has revitalised the biotechnology industry (Rothschild and Mancinelli 2001). Furthermore, the fauna adapted to extreme environments may be particularly sensitive to environmental changes, either because of the addition of potentially intolerable anthropogenic stressors or because of changes in their current environmental conditions (Catalan et al. 2006; Bellard et al. 2012); thus, such fauna can also be used as biological indicators of pollution and global change (Walther et al. 2002; Cavicchioli et al. 2011).

Among the communities present in extreme natural environments, we constantly find meiofauna organisms. Meiofauna is a collective name for a diverse assemblage of eukaryotic organisms found in both freshwater ecosystems and the marine realm (Mare 1942; Higgins and Thiel 1988; Fig. 1). They include small microscopic animals and protists, operationally defined based on the standardised mesh size of sieves with $500 \mu \mathrm{m}(1000 \mu \mathrm{m})$ as upper and $44 \mu \mathrm{m}(63 \mu \mathrm{m})$ as lower limits (Giere 2009), living in aquatic sediments. A lower size limit of 31 or $20 \mu \mathrm{m}$ has been suggested in order to retain even the smaller meiofaunal organisms in the deep sea (Giere 2009; Danovaro 2010).

Owing to their high abundance and diversity, widespread distribution, rapid generation times and fast metabolic rates, meiofaunal organisms are important contributors to ecosystem processes and functions, including nutrient cycling and provision of food to higher trophic levels, among many others (Woodward 2010; Schratzberger and Ingels 2017). Several studies have shown that meiofauna can adapt to extreme environments. The discovery of abundant and well-adapted meiofaunal communities in several environments with extreme conditions has provided new insights into the ecology and physiology of species thriving in very challenging settings (e.g. Danovaro et al. 2010b; Fontaneto et al. 2015).

In this review, we present a summary of studies that address the biodiversity, ecology and physiological responses of marine meiofauna inhabiting what appear, at least from the human perspective, to be extreme marine environments. We also discuss how the behavioural and physiological adaptations of different meiofauna taxa to these harsh conditions can provide information on how organisms may adapt to environments impacted by anthropogenic change and disturbance.

\section{Extreme environments}

According to the definition we followed in the introduction, environments can be defined as extreme if one or more of the physical or chemical variables is near the limits of what is known to be tolerable by most known life forms (e.g. extremely high or low temperatures, pressures, oxygen or salt 
Fig. 1 Representatives of selected extreme meiofaunal taxa. Light micrographs: a Richtersia sp. (nematode) from deep-sea sediments; b Neostygarctus oceanopolis (tardigrade) from deep-sea sediments. Scanning electron micrographs: c Pycnophydae (kinorhynch) from deep-sea sediments; d Virgulinella fragilis (foraminifer) from hypoxic sediments. Scale bars: a, b, $\mathbf{c}=100 \mu \mathrm{m} ; \mathbf{d}, \mathbf{e}=$ $200 \mu \mathrm{m}$. Credits: a, b D. Zeppilli (Ifremer); c N. Sanchez Santos (Ifremer); d C. Fontanier (Ifremer); e modified from Zeppilli et al. $2015 \mathrm{~b}$
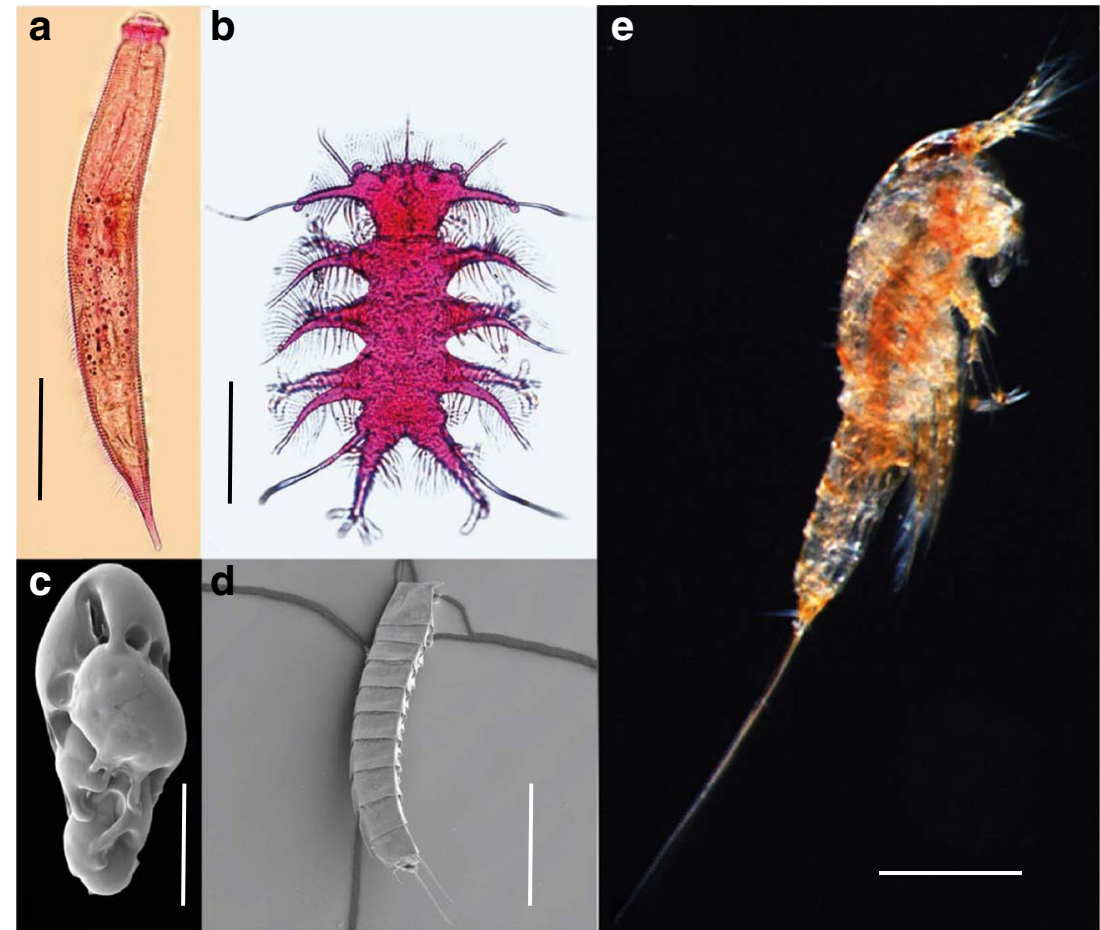

concentrations, levels of radiation, but also the presence of toxic compounds, or when such conditions vary frequently; Rothschild and Mancinelli 2001). Such environments include different habitats, from hydrothermal vents and polar areas, to mangroves and submarine caves (Table 1, Figs. 2 and 3).

\section{Mangroves}

Mangrove sediments are characterised by highly variable physical and biogeochemical conditions over time and space. These conditions result from complex sedimentary processes that are driven by a large number of interacting physical and biological factors, such as the geological and physiographical characteristics of the area, climatic conditions and the nature of mangrove vegetation (Middelburg et al. 1996; Marchand et al. 2004). On a small scale, the mangrove root habitat is exposed to extreme changes on a daily basis due to tidal cycles (Gomes et al. 2010). Mangrove are able to grow in reduced sediments due to the capacity of the plant to maintain aerobic metabolism in its roots and mechanisms for detoxifying or adapting to soil phytotoxins (Matthijs et al. 1999). Some mangroves (e.g. Rhizophora mucronata) can survive in sediments characterised by a strongly reduced substrate, a high sulphide concentration and exposure to seawater (Matthijs et al. 1999). Because of the high temporal and spatial variability in environmental characteristics, which often leads to values near the upper or lower range limits for salinity, $\mathrm{pH}$, temperature and oxygen, mangrove sediments are considered as extreme environments (Saenger 2002). During the daytime, mangrove surface sediments can reach $>50{ }^{\circ} \mathrm{C}$ (Saenger 2002). Sediments are characterised by very low concentrations of oxygen $\left(<3 \mathrm{~mol} \mathrm{~m}^{-3}\right.$; Saenger 2002) and, in some cases, they can be completely anoxic (Hogarth 1999). Surface sediment salinities can vary from oligohaline to hypersaline, depending on rainfall intensity, tidal flooding and position in the mangrove. Redox potential can vary strongly too, mainly depending on the sedimentary organic matter content and root characteristics (Matthjis et al. 1999). Mangrove sediments are largely anaerobic due to the high organic matter supply and high concentrations of silt and clay (Sukardjo 1994). However, sediments can be oxidised (suboxic), as in Avicennia stands, whereas sediments below Rhizophora trees are often anoxic and sulphidic (Nickerson and Thibodeau 1985; McKee 1993; Youssef and Saenger 1999). Reduction potential (Eh) values also vary with forest age, suggesting that oxygen release from the prop roots and pneumatophores increases when trees grow older, illustrating the influence of the rhizosphere on sediment geochemistry (Marchand et al. 2004). Mangrove trees also affect the acid-base balance of their sediments (Middelburg et al. 1996). Kristensen et al. (1988) demonstrated that Rhizophora apiculata roots lowered the $\mathrm{pH}$ of the sediments. Organic matter decomposition and sulphur oxidation can acidify the sediment in mangrove forests. In sediments from a South Kenyan mangrove with calcium carbonate content above $0.2 \mathrm{wt} \%$, the $\mathrm{pH}$ was buffered at values around 8 ; however, when calcium carbonate concentrations were lower, the buffering capacity of the sediments was not sufficient to prevent $\mathrm{pH}$ values decreasing to 3.5 (Middelburg et al. 1996). 
Table 1 A summary of meiofauna from extreme environments

\begin{tabular}{|c|c|c|c|}
\hline Ecosystem & Extreme parameters & $\begin{array}{l}\text { Stable, unstable and } \\
\text { temporary }\end{array}$ & $\begin{array}{l}\text { Meiofauna abundance and } \\
\text { diversity }\end{array}$ \\
\hline \multirow[t]{2}{*}{ Mangroves } & $\begin{array}{l}\text { Upper or lower range of } \\
\text { salinity, } \mathrm{pH} \text {, temperature } \\
\text { and oxygen }\end{array}$ & Unstable & $\begin{array}{l}\text { High abundance of nematodes } \\
\text { followed by copepods, } \\
\text { flatworms very abundant but } \\
\text { neglected }\end{array}$ \\
\hline & Presence of sulphur & & $\begin{array}{l}\text { No specialised fauna, except for } \\
\text { the leaf litter copepoda family } \\
\text { Darcythompsoniidae }\end{array}$ \\
\hline Submarine caves & $\begin{array}{l}\text { Absence of light } \\
\text { Scarce food source } \\
\text { Limited accessibility } \\
\text { Salinity gradient } \\
\text { Presence of sulphur } \\
\text { Deoxygenated }\end{array}$ & Stable & $\begin{array}{l}\text { Nematodes followed by } \\
\text { copepods, gastrotrichs, } \\
\text { tardigrades, kinorhynchs, } \\
\text { loriciferans } \\
\text { Several new species described } \\
\text { Hotspot of endemic species }\end{array}$ \\
\hline Polar ecosystems & $\begin{array}{l}\text { Low and stable temperature } \\
\text { Seasonal variations in light } \\
\text { intensity and primary } \\
\text { production }\end{array}$ & Stable & $\begin{array}{l}\text { Rotifers, nematodes, } \\
\text { foraminiferans, turbellarians, } \\
\text { copepods } \\
\text { Hotspot of endemic species }\end{array}$ \\
\hline Melting ice & $\begin{array}{l}\text { Changes thickness and salinity } \\
\text { Low and stable temperature }\end{array}$ & Temporary & $\begin{array}{l}\text { Nematodes, copepods, } \\
\text { polychaetes }\end{array}$ \\
\hline
\end{tabular}

Adaptations

Nematodes: presence of symbionts and selective bacteria feeders

Rotifers: selective bacteria feeders

Kinorhynchs: modification of plate for osmoregulation

Connection with the deep sea

Some species depend on ice for a part of life cycle

Nematodes: production of sticky substances to adhere to ice

Osmoregulatory mechanisms Migration

Kinorhynchs: osmoregulation

. followed by copepods, kinorhynchs

Hypoxic and anoxic Very low or absence of Unstable/stable environments oxygen

Foraminiferans and nematodes very abundant, copepods present

Nematodes very abundant, followed by copepods, low diversity

(shallow water and deep sea)

High temperature

Temporary

Presence of gas, heavy metals and radionuclides

Low oxygen

Deep-sea vents: high pressure, no light

Nematodes Oncholaimidae in shallow water vents,

Draconematidae and

Monhysteridae in deep-sea vents

Nematodes generalist

Copepods dirivultid endemic

Nematodes and foraminiferans very abundant, followed by copepods, presence of kinorhynchs
Foraminiferans: optimisation of oxygen capture, symbiosis, sequestration of chloroplasts, proliferation of peroxisomes and mitochondria, respiration of stored nitrate

Nematodes: detoxification strategies, high anaerobic capacity

Copepods: reduced aerobic metabolism and high values of lactate dehydrogenases

Nematodes: Oncholaimus campylocercoides produce sulphur droplets,

Halomonhystera ovoviviparism, Oncholaimus epibiotic association with microorganisms

Copepods: fast movement to escape extreme fluctuation and dirivultid haemoglobin with high affinity for oxygen

Nematodes: body form, ovoviviparism in Halomonhystera 
Table 1 (continued)

\begin{tabular}{|c|c|c|c|c|}
\hline Ecosystem & Extreme parameters & $\begin{array}{l}\text { Stable, unstable and } \\
\text { temporary }\end{array}$ & $\begin{array}{l}\text { Meiofauna abundance and } \\
\text { diversity }\end{array}$ & Adaptations \\
\hline & & & $\begin{array}{l}\text { Some seeps dominated by } 1 \text { or } \\
\text { few nematode species }\end{array}$ & $\begin{array}{l}\text { Foraminiferans: metabolic } \\
\text { adaptations }\end{array}$ \\
\hline $\begin{array}{l}\text { Carcasses and sunken } \\
\text { wood (shallow water } \\
\text { and deep sea) }\end{array}$ & $\begin{array}{l}\text { High amount of organic matter } \\
\text { Sulphur }\end{array}$ & Temporary & $\begin{array}{l}\text { Low abundance, few dominant } \\
\text { species }\end{array}$ & Stepping stones hypothesis \\
\hline Deep sea & $\begin{array}{l}\text { High pressure } \\
\text { Low temperature } \\
\text { Scarce food source }\end{array}$ & Stable & $\begin{array}{l}\text { Foraminiferans and nematodes } \\
\text { very abundant } \\
\text { High diversity with several new } \\
\text { species }\end{array}$ & \\
\hline Canyon & $\begin{array}{l}\text { Instability and physical } \\
\text { disturbance } \\
\text { Turbidity currents } \\
\text { Deep-sea conditions (low T, } \\
\text { high pressure, no light) }\end{array}$ & Unstable & $\begin{array}{l}\text { Foraminiferans and nematodes } \\
\text { very abundant } \\
\text { Different community if compared } \\
\text { with adjacent slopes }\end{array}$ & $\begin{array}{l}\text { Foraminiferans: agglutinated } \\
\text { forms instead of delicate } \\
\text { multi-chamber } \\
\text { Nematodes: opportunistic } \\
\text { (Sabatieria, Microlaimus) } \\
\text { and chemoautotrophic } \\
\text { genera (Astomonema) }\end{array}$ \\
\hline $\begin{array}{l}\text { Deep hypersaline } \\
\text { anoxic basins } \\
\text { (DHABS) }\end{array}$ & $\begin{array}{l}\text { High salinity } \\
\text { Anoxia }\end{array}$ & Stable & Only loriciferans recovered alive & $\begin{array}{l}\text { Loricifera: no mitochondria, } \\
\text { presence of hydrogenosome } \\
\text { with symbiotic } \\
\text { microorganisms }\end{array}$ \\
\hline Hadal environments & $\begin{array}{l}\text { High pressure } \\
\text { Low temperature } \\
\text { Below CCD } \\
\text { Scarce food source }\end{array}$ & Stable & $\begin{array}{l}\text { Low abundance and biomass, but } \\
\text { higher than macrofauna } \\
\text { Foraminifera and nematodes very } \\
\text { abundant }\end{array}$ & $\begin{array}{l}\text { Small size } \\
\text { No physiological studies }\end{array}$ \\
\hline
\end{tabular}

\section{Mangrove meiofauna}

In a review by Nagelkerken et al. (2008), nematodes were identified as the dominant taxon in most meiofauna studies conducted in mangrove sediments, followed by harpacticoid copepods. Although these two dominant taxa are frequently identified to lower taxonomic levels, species-level studies are scarce. According to Alongi (1987), free-living flatworms (also called 'Turbellaria') may be equally abundant, but the group is often neglected or undersampled. Meiofauna sampling and treatment techniques often destroy flatworms, leading to underestimates of their abundance. However, recent eDNA studies show that this group is very abundant (e.g. Fonseca et al. 2010). The spatial heterogeneity of mangrove sedimentary systems makes it difficult to draw general conclusions about meiofaunal diversity, since data on the number of species vary widely. Indeed, species richness tends to differ depending on the number of micro- and macrohabitats included (Somerfield et al. 1998; Nagelkerken et al. 2008; Pinto et al. 2013).

Mangroves show features that are different from other estuarine regions and may increase regional meiofauna richness. Some copepod families, like the Darcythompsoniidae, were exclusively associated with leaf litter, grazing on the associated biofilms (Somerfield et al. 1998). For nematodes, however, none of the mangrove studies so far found any evidence for a specialised fauna or an exclusively mangrove-specific taxon, as most of the genera observed are typical of intertidal, finegrained and organically enriched sediments worldwide (Nagelkerken et al. 2008). The typical leaf litter fauna is dominated by nematode genera from the family Monhysteridae, such as Diplolaimelloides and Diplolaimella, which are also found on decaying plant and algae in temperate mudflats and salt marshes. High variability in environmental conditions over time and space results in a similar high variability in density and biomass. Highest standing stocks are found in surface sediments, and anoxic and sulphidic muddy sediments, in particular, show sharp declines below the surface layers. The extreme conditions of the most organically enriched anoxic and sulphidic sediments still allow abundant meiobenthic life, even where the macrofauna becomes rare, with the exception of some capitellid polychaetes and oligochaetes.

Meiofauna taxa are numerically dominant among benthic mangrove metazoans (Pinto et al. 2013; Netto and Gallucci 2003). Nematodes withstand these extreme conditions particularly well, occasionally with high standing stocks, but with reduced diversity (Pusceddu et al. 2014). Several authors have observed that a few genera typically dominate mangrove communities, whereas most genera are quite rare (e.g. Coull 1999; Nicholas et al. 1991). Terschellingia, in particular, can account for $>50 \%$ of all nematodes (Nicholas et al. 1991), but several monhysterid genera can also be highly abundant (Pinto et al. 2013). Alongi (1987) suggested that high levels of sediment- 
associated tannins in mangrove sediments may reduce the abundance of meiofauna, but further evidence is required to test this relationship.

Litter from mangrove leaves is rapidly colonised by meiofauna, and there is a succession of different species related to the different stages of the decomposition process (Schrijvers et al. 1995; Gee and Somerfield 1997; Somerfield et al. 1998; Zhou 2001), supporting the idea that meiofauna taxa play a role in litter degradation (Gee and Somerfield 1997). The use of mangrove leaf detritus as a food source by nematodes was confirmed using isotopic markers (Demopoulos et al. 2007). The pneumatophores that are colonised by macroepibenthos, such as algae, sponges or barnacles, also promote the occurrence of meiofauna (Gwyther and Fairweather 2005; Pinto et al. 2013). Dye (1983) recorded a greater abundance of nematodes in mangrove-associated sediments in comparison with adjacent estuarine mudflats, illustrating the importance of vegetation in providing food and habitat (Sheridan 1997).

Frequently, the presence of kinorhynchs is reported in these studies as one of the "rare meiofaunal taxa", representing $<1 \%$ of the total abundance (Hodda and Nicholas 1986; Schrijvers et al. 1997; Della Patrona et al. 2016), and the phylum rarely appears with high abundance (Sarma and Wilsanand 1994; Annapurna et al. 2015). In the Itamaraca mangrove area of Brazil (Gomes et al. 2002; Santos et al. 2009), kinorhynchs ranked third in dominance after nematodes and copepods. Unfortunately, kinorhynchs found in these studies were not identified beyond the group level, except for Echinoderes bengalensis collected at Kakinada Bay (east coast of India) (Annapurna et al. 2015). Eight additional kinorhynch species have been identified in mangroves worldwide, including: Sphenoderes indicus in India (Higgins 1969); Pycnophyes alexandroi, Echinoderes belenae and Echinoderes strii in Panama (Pardos et al. 2016); Echinoderes caribiensis in Venezuela (Kirsteuer 1964); Echinoderes teretis in Australia (Nicholas and Sørenson 2009); Echinoderes komatsui in Japan (Yamasaki and Fujimoto 2014); and Echinoderes applicitus in Indonesia. These kinorhynch species were surprisingly abundant, ranking the second or third most abundant taxon in some samples (Ostmann et al. 2012).

\section{Adaptation of meiofauna to mangrove conditions}

Most of the meiofauna genera are not restricted to mangroves, and most species do not show obvious adaptations to the extreme conditions. However, several chemosynthetic species have been found in mangroves. Genera such as Parastomonema, a mouthless group of nematodes with chemosynthetic endosymbionts, and the Stilbonematinae, elongated nematodes covered by ectosymbiotic bacteria, are typically found in anoxic environments rich in methane or sulphide (Ott et al. 2004) and occasionally occur in mangrove sediments (Somerfield et al. 1998; Kito and Aryuthaka 2006). Moreover, Bouillon et al. (2008) reported that mangrove invertebrates may show very specialised pathways of carbon and nitrogen acquisition through symbiotic relationships based on highly depleted $\delta^{13} \mathrm{C}$ natural isotope values. The Stilbonematinae species Eubostrichus dianae (Hopper and Cefalu 1973) was found on decaying wood where sulphides are being produced from the decomposition of organic matter in a mangrove from Guadalupe (Maurin et al. 2010). Kito and Aryuthaka (2006) described a new species of the mouthless genus Parastomonema collected in muddy sediments of a mangrove forest in Samut Songkhram, Thailand. Pascal et al. (2014) studied the endofauna of bacterial mats between mangrove tree roots and found no differences in abundance with surrounding mangrove, suggesting that this chemosynthetic food source had a limited impact on the structure of the mangrove food web. Both natural isotopic compositions and a ${ }^{13} \mathrm{C}$ enrichment study demonstrated the uptake of bacterial mats only by associated meiofauna, mainly by rotifers and, to a lesser degree, by small polychaetes and nematodes, and not by the macrofauna (Pascal et al. 2014). On the contrary, the cosmopolitan gnathostomulid species Haplognathia ruberrima was found in sulphur bacterial mats in Guadeloupe mangroves with $\delta^{13} \mathrm{C}$ values lower than the available measured food sources of this environment. Since no sulphur-oxidising symbionts were observed, it was suggested that the species was grazing selectively and exclusively on the free-living, sulphur-oxidising bacteria (Pascal et al. 2014).

The so-called Echinoderes coulli group within the kinorhynch genus Echinoderes is believed to be adapted and specialised to cope with fluctuating salinities, tolerating both brackish and hypersaline waters (Omer-Cooper 1957; Higgins 1977; Horn 1978; Brown 1985; Ostmann et al. 2012; Yamasaki and Kajihara 2012; Sørensen 2014). These species have a modified, enlarged nephridial sieve plate that is likely related to a high osmoregulation efficiency (Ostmann et al. 2012).

\section{Submarine caves}

Submarine caves are oligotrophic environments due to insufficient light for photosynthesis and reduced input of organic material, limited accessibility for surface marine fauna and a steep salinity gradient in anchialine caves (Fichez 1990; Sket 1996). Some caves can be sulphurrich and deoxygenated environments where chemoautotrophic microorganisms take advantage of the sharp redox interfaces in the cave water column to reduce inorganic carbon using compounds such as sulphides or ammonium as electron donors (Jaume and Boxshall 2009). In some caves of volcanic origin, hydrogen sulphide can reach concentrations of $>300 \mu \mathrm{M}$ (Riesch et al. 2010). 


\section{Mangroves}

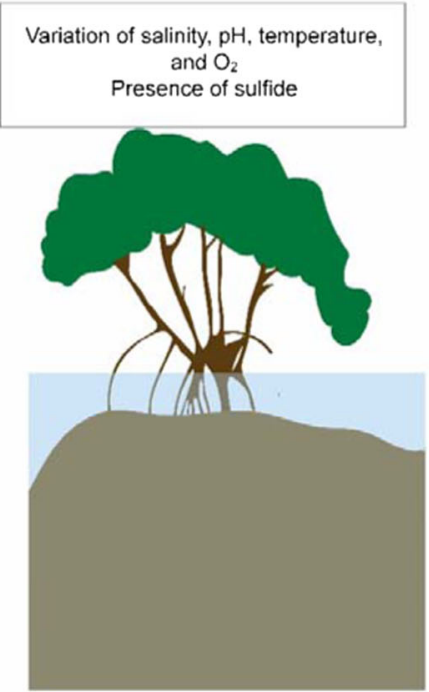

a

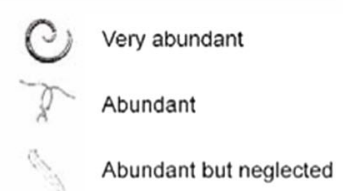

Hyper saline zones
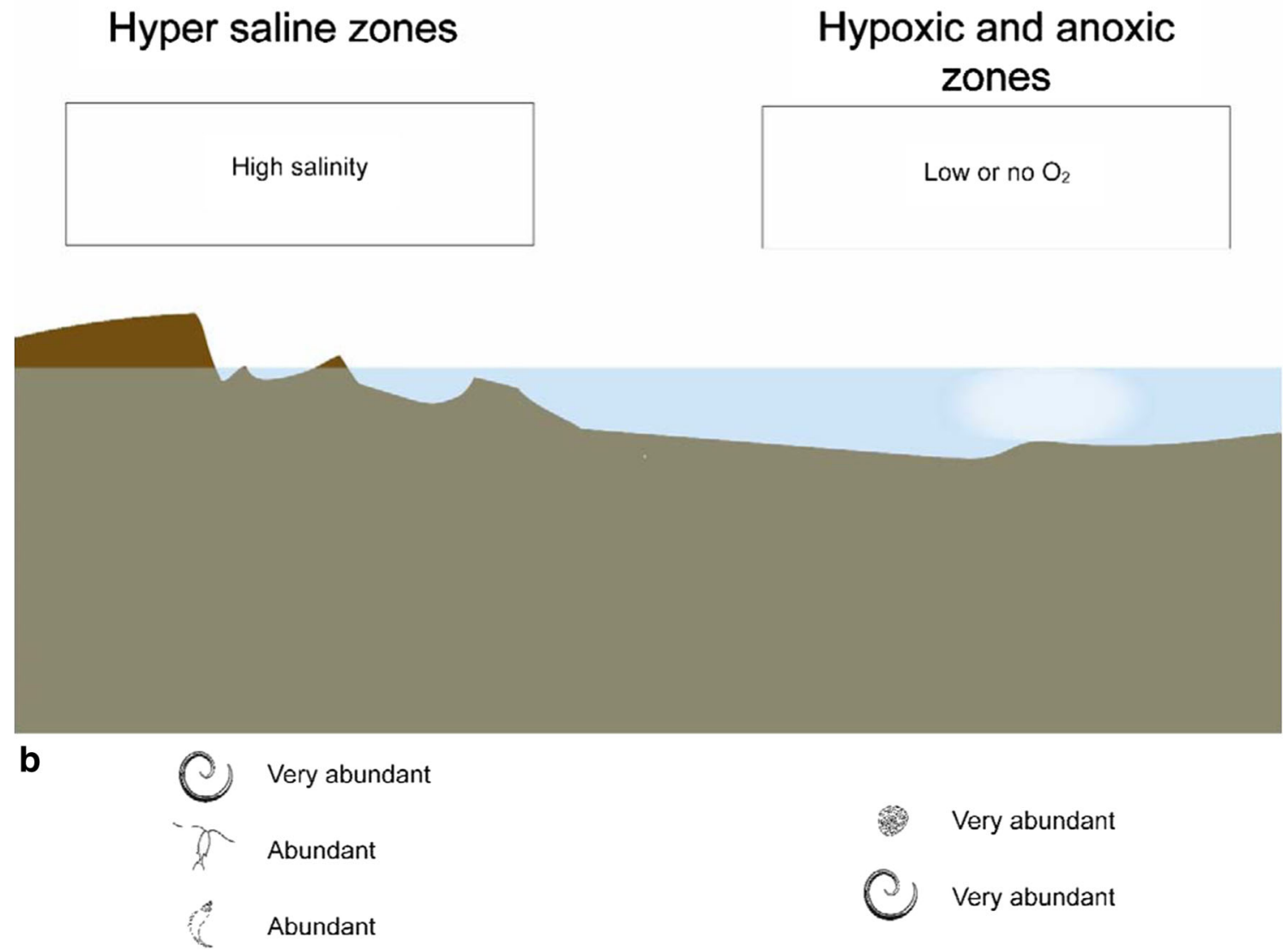

b
Submarine caves

$$
\begin{aligned}
& \text { Low light } \\
& \text { Low food } \\
& \text { Presence of sulfide }
\end{aligned}
$$

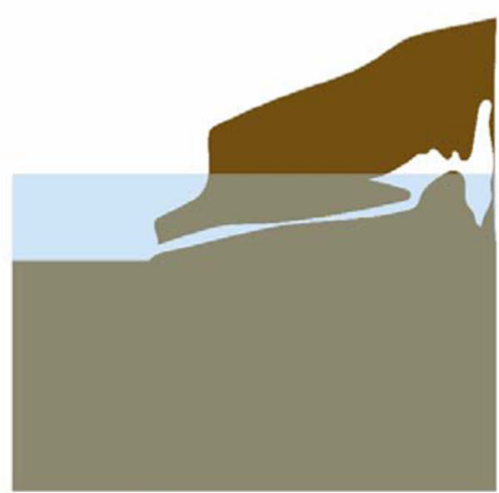

$$
\text { (3) Abundant }
$$

Polar ecosystems

and melting ice

Low temperature Variation of salinity

69 Very abundant

$$
\text { Very abundant }
$$

Abundant

Abundant
Hypoxic and anoxic zones

Low or no $\mathrm{O}_{2}$

Fig. 2 Schematic representation of meiofauna from: a mangroves, submarine caves and Polar ecosystems and melting ice, and $\mathbf{b}$ hypersaline zones and hypoxic and anoxic zones 
Hydrothermal vents

\begin{tabular}{|c|}
\hline High temperature \\
Low $\mathrm{O}_{2}$ \\
Presence of sulfide and heavy metals
\end{tabular}

Carcasses and woods

High organic matter

Presence of sulfide

\section{Cold seeps}

\section{Low $\mathrm{O}_{2}$}

Presence of reduced chemical com pounds

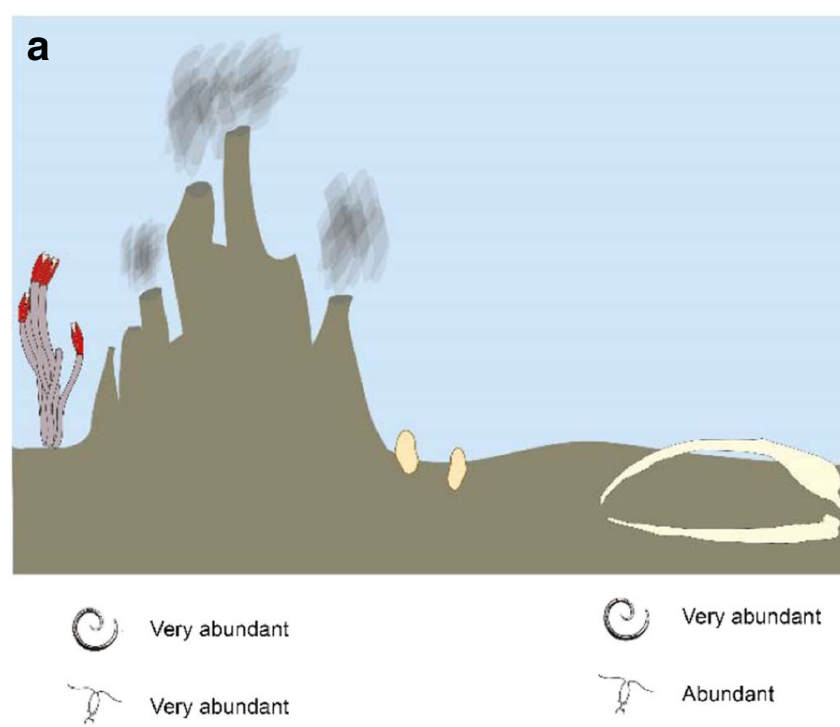

Canyons Instability and currents Low temperature High pressure

\section{DHABs}

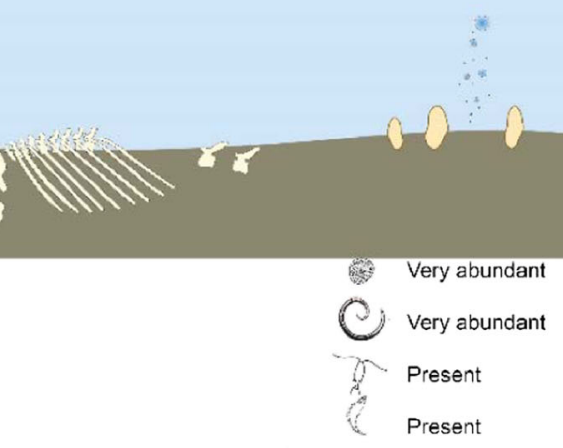

Hadal zones

High pressure

Low temperature Generally low food

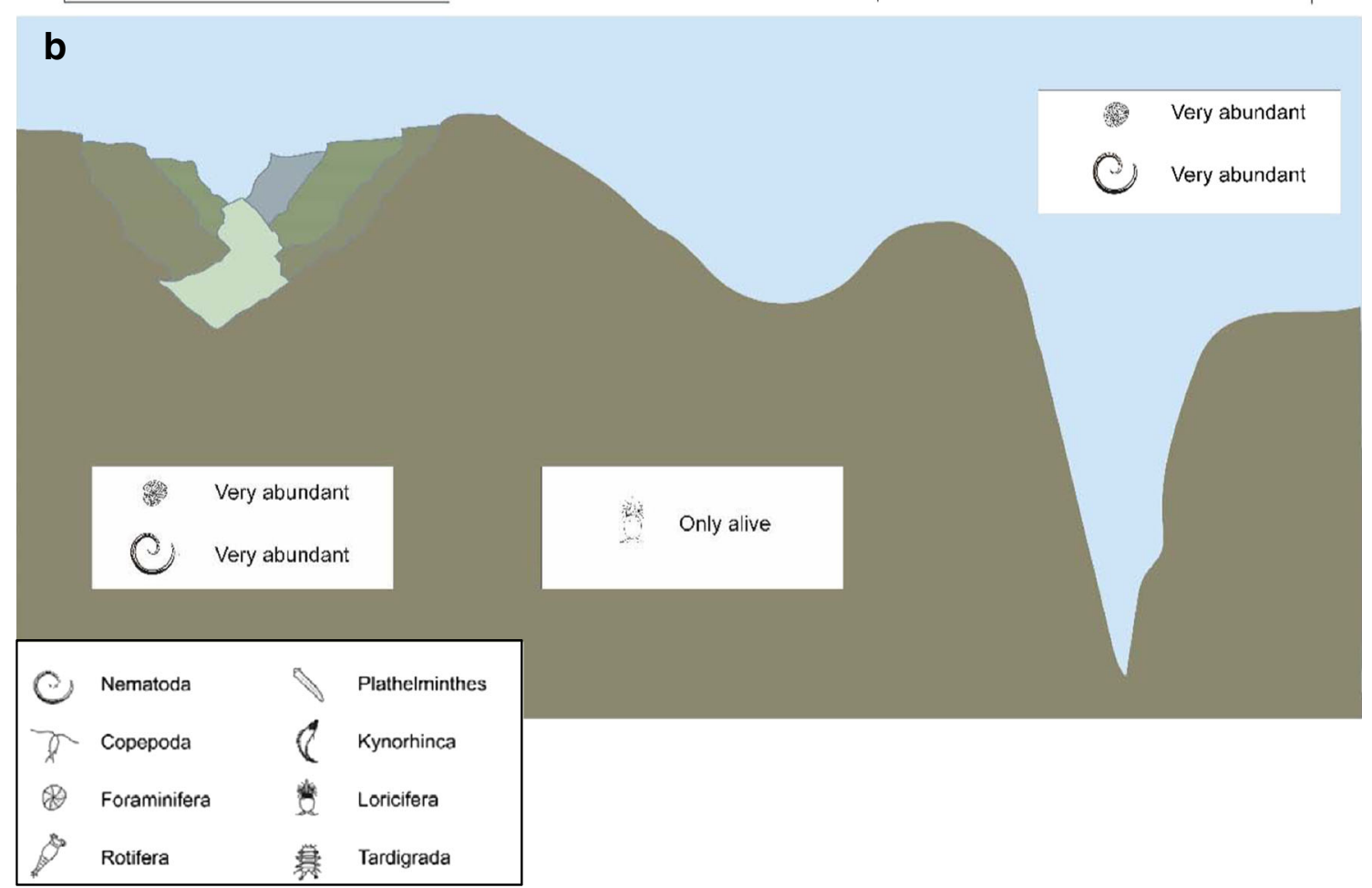

Fig. 3 Schematic representation of meiofauna from: a hydrothermal vents, carcasses and sunken woods and cold seeps, and $\mathbf{b}$ canyons, deep hypersaline anoxic basins (DHABs) and hadal zones 
These habitats host a unique fauna (Iliffe and Kornicker 2009; Juan et al. 2010) and because they represent independent evolutionary trajectories of adaptations to similar conditions, similar to islands for the terrestrial environment, they are considered one of the most important habitats to study marine island biogeography (Dawson 2016).

\section{Meiofauna from submarine caves}

Despite the enormous interest that marine cave systems generate, mainly due to their very peculiar environmental conditions, a comprehensive study of meiofauna in such systems is yet to be conducted. However, some efforts were made in the past (i.e. Wieser 1954; Pesta 1959) and more recently (Palacin and Masalles 1986; Palacín et al. 1992; Grimaldi de Zio et al. 1982a, b; Villora-Moreno 1996; Sandulli et al. 1999; Todaro et al. 2006; Ape et al. 2015; Janssen et al. 2013). Several marine caves in the Mediterranean Sea, Atlantic Ocean and Australia have been investigated for the presence of meiofauna. Many species of nematodes, gastrotrichs, tardigrades, crustaceans, polychaetes and aplacophorans were found and several new species of tardigrades (Grimaldi de Zio et al. 1982a, b; Villora-Moreno 1996; Boesgaard and Kristensen 2001; Gallo D'Addabbo et al. 2001; Martínez García et al. 2009; Jørgensen et al. 2014), kinorhynchs (Sørensen et al. 2000), gastrotrichs (Todaro et al. 2001) and priapulids (Todaro and Shirley 2003; Schmidt-Rhaesa et al. 2013) were also described.

Most of the studies indicate that the submarine cave meiofauna comprises distinct and diverse communities. They may share some similarity with abyssal meiofauna due to the comparable environment (i.e. no light, weak hydrodynamic conditions, limited food availability) and a potential common origin (Janssen et al. 2013). From an evolutionary point of view, caves can harbour uniquely adapted organisms (Iliffe and Kornicker 2009; Juan et al. 2010). In the Mediterranean Sea (Grotta Piccola del Ciolo, Ionian Sea), Todaro et al. (2006) found very high meiofaunal abundance, with nematodes and harpacticoid copepods as the most dominant groups. Gastrotrichs, with 16 species, accounted for almost $3 \%$ of the total meiofauna. In a cave from Tenerife Island (Atlantic Ocean), a high spatial variability of meiofauna community was observed because of the cave complexity (secondary openings and freshwater inputs) and variable hydrodynamic conditions (tides and rough seas, due to shallow depths and orientation of the entrance; Riera et al. 2016). Sørensen et al. (2000) showed that the meiofauna from an Australian cave was principally composed of several new species of nematodes belonging to the genera Dracograllus and Desmoscolex, harpacticoid copepods, polychaetes of the genera Mesonerilla and Nerillidium, gastrotrichs of the genera Xenodasys, Chordodasys and
Polymerurus, interstitial aplacophorans and loriciferans belonging to the genera Pliciloricus and Australoricus.

Marine tardigrades seem to be among the most studied taxa, with the first report dating back to 1982, when studies of the Cattedrale Cave (Lecce, Italy) and the Mitigliano Cave (Sorrento, Naples, Italy) were carried out (Grimaldi de Zio et al. 1982a, b). In these studies, five new species were identified and described (Neostygarctus acanthophorus, Chrysoarctus flabellatus, Tanarctus longisetosus, Actinarctus physophorus and Actinarctus neretinus), while others were identified as known species (Wingstrandarctus intermedius, Dipodarctus subterraneus, Florarctus hulingsi, Tanarctus tauricus and Batillipes littoralis). However, none of these species are exclusively stygobiont. More recently, a new species Trogloarctus trionyches (Villora-Moreno 1996) belonging to the family Coronarctidae, which is typical for abyssal sediments, was found in the Trois Pépés Cave near Marseille (France). This family had not been observed in the Mediterranean Sea, and this finding provided further support to the theory of species exchange through sea-floor dispersal (Hart et al. 1985).

More recently, in the same cave, Janssen et al. (2013) found remarkably high copepod diversity, but with lower diversity towards the inner parts of the cave where tardigrades were dominant. This cave was characterised by low meiofaunal abundance; however, a total of 90 copepod species $(75 \%$ new to science) were collected from this site. Some of these copepod taxa, such as the genera Marsteinia, Ancorabolina, Paranannopus and Nematovorax, and the family Argestidae, were already known from the deep sea. Boesgaard and Kristensen (2001) studied the relatively diverse tardigrade fauna of two Australian submarine caves (Jim's Cave and Fish Rock Cave). The tardigrade genera collected were: Actinarctus, Batillipes, Dipodarctus, Halechiniscus, Raiarctus, Styraconyx, Tanarctus, Tholoarctus and Wingstrandarctus. The finding of Actinarctus neretinus, previously described from an Italian submarine cave (Grimaldi de Zio et al. 1982b), supports the theory that cave meiofauna might be related to the deep-sea fauna, as suggested by Danielopol (1990), and that caves could be considered as 'refuges' for ancient fauna dating back to Tethys (Janssen et al. 2013). Gallo D'Addabbo et al. (2001) described two new species of tardigrades (Parastygarctus mediterraneus and Pseudostygarctus rugosus) from two submarine caves of St. Domino Island (Violets Cave and Moray Eels Cave, Tremiti Islands, Italy), along with 23 additional species already known from the Mediterranean. Most recently, a new tardigrade genus and species Quisarctus yasumurai was found in a Japanese submarine cave off Iejima, Ryukyu Islands (Fujimoto 2015).

Even though kinorhynchs occur frequently in submarine caves, they always appear in lower numbers than nematodes, copepods, priapulids or annelids (Janssen et al. 2013; Riera 
et al. 2016). The collected specimens have occasionally been identified to the species level: Echinoderes dujardinii from the Italian and Iberian Peninsula (Riedl 1966), Meristoderes macracanthus from Sardinia (Dal Zotto and Todaro 2016), Echinoderes cavernus from Australia (Sørensen et al. 2000) and Ryuguderes iejimaensis from Japan (Yamasaki 2016). Of these four species, only the latter two can be considered as exclusive cave-dwelling kinorhynchs, since the others have also been collected in other environments. The only two loriciferan species known from caves, Pliciloricus cavernicola and Australoricus oculatus, were described from marine caves in New South Wales, Australia (Heiner et al. 2009).

\section{Polar ecosystems and melting ice}

Polar environments are characterised by low and stable temperatures (Huntley and Lopez 1992), and are influenced by significant seasonal variation in light intensity and, consequently, primary production (Clarke and Peck 1991; Hagen and Auel 2001). Arctic and Antarctic ecosystems differ in both the amplitude and nature of their ice cover (Cavalieri et al. 2003). The Arctic Ocean has multi-year ice with small variations in extension (a minimum of $7 \times 10^{6} \mathrm{~km}^{2}$ in summer and a maximum of $17 \times 10^{6} \mathrm{~km}^{2}$; Maykut 1985). In winter 2016, the Arctic sea ice winter maximum peaked at $14.52 \times 10^{6} \mathrm{~km}^{2}$, the new lowest record since 1979 (https:// www.nasa.gov). The Antarctic Ocean consists mainly of seasonal ice (Brierley and Thomas 2002) and changes in ice cover are larger than in the Arctic, with a maximum of $19 \times 10^{6} \mathrm{~km}^{2}$ during winter and a minimum of $2 \times 10^{6} \mathrm{~km}^{2}$ during summer (Comiso and Nishio 2008). Ice cover is formed when seawater freezes (temperatures below -1 . $8{ }^{\circ} \mathrm{C}$; Eicken 1992) and the resulting ice crystals float to the surface. Ice crystals form aggregates containing microalgae with very high standing stocks (Schnack-Schiel et al. 2001 and references therein). A network of fluid-filled brine channels surrounds the ice crystals, exceeding $30 \%$ of the sea ice volume in summer (Horner 1985). Within the brine channel network, living organisms are exposed to extremes of temperature and salinity (temperatures from below $-15^{\circ} \mathrm{C}$ in winter to $0{ }^{\circ} \mathrm{C}$ in summer and salinity variation from 0 to over 200 PSU; Gradinger 2001).

\section{Meiofauna from polar ecosystems}

Marine polar ecosystems had long been considered desert-like environments with only a low number of species being able to survive the harsh conditions (Fogg 1998). However, knowledge about Arctic and Antarctic ecosystems has recently increased and, today, we know that polar ecosystems host a diverse community characterised by endemic species (Conover and Huntley 1991; De Broyer et al. 2014; George
2014; Gooday et al. 2014; Ingels et al. 2014). This ice forms a habitat for meiofaunal organisms such as heterotrophic flagellates, ciliates, rotifers, nematodes, foraminiferans, turbellarians and copepods (Spindler et al. 1990; Blome and Riemann 1999; Gradinger 1999; Schnack-Schiel et al. 2001; Michel et al. 2002; Schnack-Schiel 2003). Hauquier et al. (2015) showed that not only megabenthic but also smallersized meiobenthic communities respond to different oceanographic regimes around the Antarctic Peninsula. Meiofauna can also be associated with the brackish layer formed under the ice. This sympagic meiofauna consists of both metazoans and protozoans (Gradinger 1999).

Monothalamous foraminiferans are a major component of the benthic meiofauna in high-latitude regions (Pawlowski et al. 2008). In the Antarctic Peninsula, foraminiferans accounted for up to $83 \%$ of all meiofaunal organisms and comprised species also found in other oceanic regions (Cornelius and Gooday 2004). High genetic similarity was detected between Arctic and Antarctic populations of three common deep-sea foraminiferal species separated by distances of up to 17,000 km (Pawlowski et al. 2007).

The metazoan meiofauna in Antarctic coastal sediment of Factory Cove, Signy Island was highly abundant compared to sublittoral sediments worldwide (Vanhove et al. 1998). Meiofauna abundance from the South Sandwich Trench decreased with increasing water depth, with higher values on the trench floor compared to most other oceans' trench regions (Vanhove et al. 2004). The meiofauna communities in the region off Kapp Norvegia, Antarctica (at water depths between 211 and $2080 \mathrm{~m}$ ) were primarily influenced by bathymetric depth and food availability, and were directly related to phytoplankton blooms and associated sedimentation pulses (Vanhove et al. 1995). At Potter Cove (west Antarctic Peninsula), meiofaunal abundances were higher in summer and lower in winter due the combination of food quality and competition for food among higher trophic levels (Pasotti et al. 2014). Melting ice meiofauna is composed mainly of nematodes, copepods and polychaetes (Lønne and Gulliksen 1991; Hop et al. 2000; Scott et al. 2002; Gradinger et al. 2005). Some of these species depend on the ice at least for a part of their life cycle (Legendre et al. 1992).

Rotifers are very common and abundant in polar areas (Kaya et al. 2010; Fontaneto et al. 2015). Indeed, the famous explorer Ernest Shackleton noticed them during the first explorations of Antarctica: "The microscope showed that rotifers, water-bears, and other forms of minute animal-life existed" (Shackleton 1909). Rotifers are abundant in almost every habitat that has been sampled in the Antarctic regions, including permanent water bodies in freshwater, brackish and marine waters, and also mosses, lichens, soils and habitats such as glaciers, meltwater pools, algal mats and cryoconite holes (Fontaneto et al. 2015). Together with nematodes and 
tardigrades, rotifers are widely found in the coastal areas of Antarctica (Convey and McInnes 2005).

Nematodes have been shown to dominate polar metazoan meiofauna (Heip et al. 1985; Vanhove et al. 1995, 1998, 1999, 2004; Fabiano and Danovaro 1999; Lee et al. 2001; De Mesel et al. 2006; Ingels et al. 2006; Ingole and Singh 2010; Vanreusel et al. 2000; Hauquier et al. 2015). In the Southern Ocean, some species might be limited to certain regions or depths, while others may have circum-Antarctic and eurybathic distributions (Ingels et al. 2014). In the Central Arctic, the dominance of the nematode genus Monhystera, a detritivorous/bacterivorous deposit feeder, suggests that bacteria may play an important role in the food web of the meiofauna in this region (Vanreusel et al. 2000).

\section{Adaptation of meiofauna to polar conditions}

Meiofauna in polar oceans is highly endemic (Conover and Huntley 1991) and particularly adapted to these environments. The bulk of benthic meiofauna feeds on degraded organic matter, a food source available throughout the year (VeitKöhler et al. 2013). Variations in meiofauna abundance and community structure can be explained by the input and availability of organic matter (Vanhove et al. 2000). Isotopic analysis on Antarctic meiofauna suggested a detrital-pool food source and/or the presence of predatory taxa (Pasotti et al. 2015). The dominant nematode genus Daptonema also appears able to feed on both bacteria and diatoms (Pasotti et al. 2012). An experiment performed by Ingels et al. (2010) showed that bacteria were preferred over fresh phytoplankton as a carbon source for both Arctic and Antarctic deep-sea nematode communities, suggesting that bacteria may provide a pathway through which unused detritus may enter the classical metazoan food web (Pasotti et al. 2015).

Changes in salinity and ice thickness can negatively affect meiofaunal communities (Gradinger et al. 2010). Meiofaunal organisms living in the melting ice have osmoregulatory mechanisms allowing them to survive across a wide spectrum of salinities (Aarset 1991; Friedrich 1997; Gradinger 2002; Kiko et al. 2009). The respiration rates of some Arctic amphipod species increase 2-3 times at salinities below 15 PSU and the amphipod Gammarus wilkitzkii is able to maintain high concentrations of inorganic ions in the haemolymph at salinities down to 5 PSU (Aarset 1991; Gradinger 2001). When salinity decreases drastically, freshwater taxa dominate (Gradinger et al. 2010). To avoid salt stress, amphipods can swim and select more suitable depth and ice structures (Gradinger and Bluhm 2004). Similarly, meiofauna living within the ice migrates into the water column and colonise the surrounding ice (Gradinger et al. 2010). An active migration can explain the positive relationship found between ice meiofauna density and salinity, in particular for flatworms (Gradinger et al. 2010). Meiofauna density increases significantly during periods of ice melt in the waters below the sea ice (Werner and Martinez Arbizu 1999; Werner 2006) and it has been hypothesised that meiofauna could then be able to choose the ice with suitable environmental conditions (Gradinger et al. 2010). In addition, some nematodes (e.g. Monhysteridea) produce sticky substances in order to adhere to the ice and avoid being released into the water column during melting (Riemann and Sime-Ngando 1997). The water generated by melting ice can be murky due to high concentrations of nutrients, providing visual protection against predators (i.e. young cod in the Franklin Bay; Hop et al. 2011).

\section{Hypersaline areas}

Marine hypersaline areas are extreme habitats in which the salinity is significantly higher than that of seawater (34130 PSU; Kaiser et al. 2005). Some of these areas are found in the Mediterranean Sea and in the Red Sea (Ólafsson et al. 2000). Human activities, such as desalination plants, can also generate hypersaline zones.

\section{Meiofauna from hypersaline areas}

Several nematodes and harpacticoid copepods are adapted to hypersaline conditions (Carrasco and Perissinotto 2012). In the discharge area of desalination plants in the Canary Islands, substantial changes in the abundance of nematodes and copepods have been recorded (Riera et al. 2011). Meiofaunal abundance increased in sediments underneath the discharge and nematodes dominated impacted stations (Riera et al. 2011). Meiofauna assemblages (mainly foraminiferans and ostracods) were reported from saltpans, hypersaline lagoons and salt lakes of the Gulf of Saros (Turkey; Bassler-Veit et al. 2013). High kinorhynch abundances were observed in a lagoon area in Java, Indonesia, where salinity levels vary from $24 \%$ o to $41 \%$ (Ostmann et al. 2012); in the Itamaraca mangrove area (Brazil), where salinity levels reach 40-44\%o (Gomes et al. 2002); as well as in the Rio Formoso Estuary (Brazil), where the salinity is $37 \%$ (Vasconcelos et al. 2004; see salinity adaptations in the mangroves section). In high saline areas of the Red Sea, Gerdes et al. (1985) found only one nematode species, Oncholaimus oxyuris, present in the sediment.

\section{Hypoxic and anoxic environments}

Hypoxic environments are characterised by reduced availability of dissolved oxygen $(<0.2 \mathrm{~mL} / \mathrm{L}$; Kamykowski and Zentara 1990). In shallow waters, oxygen depletion is often a seasonal phenomenon that can be exacerbated by anthropogenic activities. Especially in coastal waters, enhanced 
nutrient input by river runoffs often results in eutrophication that induces increased biomass production and, subsequently, higher oxygen consumption due to microbial activities (Diaz and Rosenberg 1995; Rabalais et al. 2010). In deeper waters, naturally occurring oxygen minimum zones (OMZs) are located mainly in the eastern Pacific, the Arabian Sea and the Bay of Bengal (Helly and Levin 2004). Hypoxic environments can eventually become anoxic, with a total absence of dissolved oxygen in the bottom water and sediment pore water (Diaz 2001). The deep Black Sea is one example of an anoxic environment. Below $150 \mathrm{~m}$ depth, the Black Sea is characterised by low oxygen concentrations $(0.1-0.3 \mathrm{~mL} / \mathrm{L}$; Sergeeva et al. 2011), and it is anoxic and sulphidic below depths of 200-250 m.

\section{Meiofauna from hypoxic and anoxic environments}

Prolonged exposure to hypoxic conditions negatively affects the entire meiofaunal community, with a decrease in meiofaunal densities and disappearance of many species and life stages (Murrell and Fleeger 1989; Diaz and Rosenberg 1995; Wetzel et al. 2001; Revkov and Sergeeva 2004; Ingels et al. 2013; Sergeeva and Zaika 2013). However, meiofauna is generally more tolerant to low concentrations of oxygen than macrofauna (Giere 1993). With oxygen concentrations below $0.1 \mathrm{~mL} / \mathrm{L}$, the fauna is comprised mainly of small organisms, foraminiferans and nematodes in particular (Levin 2003; Gooday et al. 2009b), while macrofaunal organisms are rare (Gooday et al. 2000, 2009a, b; Levin 2003). Meiofaunal composition varies according to changes in the hypoxic zone (Revkov and Sergeeva 2004). In the Gulf of Mexico, a dramatic decrease in the abundance and biomass of meiofauna is associated with hypoxia and anoxia (Murrell and Fleeger 1989). The foraminifera species Virgulinella fragilis was recorded in Walvis Bay sediments (Benguela shelf, West Africa), where the sub-thermocline is perennially hypoxic (Tsuchiya et al. 2009; Levin et al. 2009). In the Black Sea, the extreme conditions prevent colonisation by aerobic benthic organisms (Sergeeva et al. 2013), although there is recent evidence that some benthic metazoans and protists can survive in anoxic and sulphidic habitats at depths of almost $300 \mathrm{~m}$ near the outflow area of the Bosphorus in the western Black Sea (Sergeeva et al. 2014). Meiofauna from hypoxic and anoxic environments is reviewed in detail by Zeppilli et al. (2015b).

\section{Adaptation of meiofauna to hypoxia and anoxia}

Behavioural (escape, predation reduction) and physiological responses (growth rate decrease, dormancy, initiation of anaerobic metabolism) to hypoxic conditions have been recorded in meiofauna (Rabalais et al. 2002). Several studies showed that nematodes are generally more resistant to hypoxia than copepods (Murrell and Fleeger 1989; Modig and Olafsson 1998; Grego et al. 2013; Sergeeva and Zaika 2013). Nematodes are adapted to these extreme conditions (e.g. Odontophora spp.; Van Colen et al. 2009) with detoxification strategies and high anaerobic capacity (Veit-Köhler et al. 2009; Vopel et al. 1998). Harpacticoid copepods are the most sensitive meiofauna taxa to low oxygen concentrations (De Troch et al. 2013). Mechanisms that allow foraminiferans to live in hypoxic/anoxic sediments are: (1) optimisation of oxygen capture (by smaller dimension and thinner and more porous shell; Bradshaw 1961; Phleger and Soutar 1973; Perez-Cruz and Machain-Castillo 1990; Sen Gupta and Machain-Castillo 1993; Bernhard and Sen Gupta 1999; Gooday et al. 2000; Levin 2003); (2) the presence of bacterial endosymbionts (e.g. Bernhard 2003); (3) the sequestration of chloroplasts (Bernhard and Bowser 1999; Grzymski et al. 2002); (4) the proliferation of peroxisomes and mitochondria (Bernhard and Bowser 2008); and (5) the respiration of stored nitrate (Risgaard-Petersen et al. 2006; Woulds et al. 2007; Gooday et al. 2009a, b; Piña-Ochoa et al. 2010a, b; Glock et al. 2012; Koho and Piña-Ochoa 2012; Mallon et al. 2012; Fontanier et al. 2014a). Nematodes are adapted to hypoxia/ anoxia with detoxification strategies and high anaerobic capacity (Veit-Köhler et al. 2009; Vopel et al. 1998), and can be used to detect changes in oxygen levels in marine environments (Zeppilli et al. 2015b). Adaptations of meiofauna to hypoxic and anoxic environments are reviewed in detail by Zeppilli et al. (2015b).

\section{Hydrothermal vents}

Hydrothermal vents are the result of seawater percolating up through fissures in the ocean crust in the vicinity of spreading centres and back-arc basins. The cold seawater is heated by the rocks in contact with the magma chamber, enriched in different chemicals and remerges to the seafloor to form hot vents. These ephemeral habitats have a longevity that is directly related to the character of the underlying magma (Van Dover 2000). Life in these environments requires the organisms to develop specific adaptations to cope with the extreme abiotic conditions and the patchy nature of vent ecosystems. Particular challenges are posed by the presence of: (1) high concentrations of reduced compounds such as hydrogen sulphides, low oxygen levels and the presence of heavy metals and radionuclides (Sarradin et al. 1999; McMullin et al. 2000; Charmasson et al. 2009); (2) high temperature gradients from a few ${ }^{\circ} \mathrm{C}$ in the surrounding seawater up to $400{ }^{\circ} \mathrm{C}$ in the black smokers; and (3) patchy and ephemeral distribution of venting activity on the seafloor (Tunnicliffe 1991). Shallow-water hydrothermal vents typically release free gas and hot water, creating extreme local conditions variable in space and time (Tarasov et al. 2005; Zeppilli and Danovaro 2009). The 
presence of light, coupled with that of geothermal fluids, promotes both photo- and chemosynthetic primary production (Tarasov et al. 2005).

\section{Meiofauna from hydrothermal vents}

The fauna of shallow-water vents is different from that found at deep-sea vents (Tarasov et al. 2005). In contrast to deep-sea hydrothermal vents, shallow-water vents are characterised by non-endemic vent meiofauna characterised by higher diversity and abundance than in background sediments (Tarasov et al. 2005). Nematodes dominate sites with high fluid emissions, while copepods are dominant in sediments with moderate emissions (Coull 1985; Colangelo et al. 2001; Zeppilli and Danovaro 2009). Compared with deep-sea vents, where none of the nematode species found in hydrothermal sediments occur in the surrounding sediments (Vanreusel et al. 1997), nematodes inhabiting shallow vent areas include a subset of species that live in background sediments far away from the vent sites but are also able to survive in extreme conditions. None of the shallow-water vent copepods are specific or related to copepods specific to the deep-sea hydrothermal vents, suggesting that the populations close to shallow vents are the result of colonisation from adjacent areas (Zeppilli and Danovaro 2009).

In recent years, the deep-sea hydrothermal vent meiofauna has increasingly gained interest and several studies have been published (Vanreusel et al. 1997; Tsurumi et al. 2003; Zekely et al. 2006a, b; Copley et al. 2007; Gollner et al. 2007, 2010b, 2013; Limén et al. 2007; Degen et al. 2012; Cuvelier et al. 2014; Sarrazin et al. 2015). Meiofauna is considered to contribute up to $20 \%$ of the total diversity known from deep-sea hydrothermal vents (Bright 2006). In the vicinity of deep-sea vents, meiofauna can be associated with habitats ranging from inactive bare basalts (Gollner et al. 2010b) and sediments (Vanreusel et al. 1997) to diffuse vent flow areas colonised by macrofaunal assemblages (Zekely et al. 2006a, c; Sarrazin et al. 2015). Almost all studies that include meiofauna were conducted along the East Pacific Rise (EPR; Dinet et al. 1988; Flint et al. 2006; Gollner et al. 2006, 2007, 2010b; Zekely et al. 2006a, b, c; Copley et al. 2007; Limén et al. 2007, 2008), with the exception of four studies: two in the West Pacific back-arc basins (Shirayama 1992; Vanreusel et al. 1997) and three on the Mid-Atlantic Ridge (MAR; Zekely et al. 2006a, b, c; Cuvelier et al. 2014; Sarrazin et al. 2015). The picture emerging from these studies points to a vent meiofauna with low abundance and diversity (Dinet et al. 1988; Vanreusel et al. 1997; Tsurumi et al. 2003; Copley et al. 2007; Limén et al. 2007; Gollner et al. 2010b) compared with other chemosynthetic ecosystems characterised by less extreme conditions. Their distributions vary with the abiotic conditions of the habitat (Gollner et al. 2010b; Sarrazin et al. 2015) and the presence of bacterial mats and large engineer species, such as mussels and tubeworms (Zekely et al. 2006a, c; Gollner et al. 2010b; Degen et al. 2012). In the Atlantic, meiofauna represent at least $50 \%$ of the total diversity in vent fauna and meiofaunal communities are dominated by generalist nematodes and endemic copepods (Zekely et al. 2006a, c; Sarrazin et al. 2015). Nematodes identified in deep-sea vents generally belong to families and genera already known from non-vent habitats (Dinet et al. 1988; Vanreusel et al. 1997; Zekely et al. 2006c), although, at the species level, none of the nematode species found in the hydrothermal sediments occur in the surrounding abyssal areas (Vanreusel et al. 1997; Setoguchi et al. 2014). Nematodes belonging to the family Oncholaimidae have been reported close to the source of the emissions at shallow hydrothermal vents worldwide (Thiermann et al. 1994; Dando et al. 1995; Zeppilli and Danovaro 2009). The nematode community composition from a hydrothermal vent field located in the caldera of the Myojin seamount on the Izu-Ogasawara Arc (Japan) was significantly different from that in the nonhydrothermal areas around the caldera (Setoguchi et al. 2014). Nematode studies at $9^{\circ} 50^{\prime} \mathrm{N}$ on the EPR reveal low nematode diversity and high dominance of single species (Flint et al. 2006; Zekely et al. 2006a; Gollner et al. 2007,2010 b). Species richness is inversely correlated with the intensity of vent fluid emissions (Gollner et al. 2010b, 2015). In their recent study, Gollner et al. (2015) showed that, unlike the majority of macrofaunal species, meiofaunal species were distributed across proximate and distant basalt habitats and were, thus, not restricted to vent habitats.

Copepods represent an important taxonomic group at deepsea vents, with more than 80 described species representing 20 families and six orders (Heptner and Ivanenko 2002; Ivanenko and Defaye 2006). Most of the copepod species (53) belong to the family Dirivultidae (order Siphonostomatoida), which has only been reported from hydrothermal vent ecosystems (Humes and Dojiri 1980; Gollner et al. 2010a; Ivanenko and Ferrari 2013). Dirivultidae have a worldwide distribution, but most genera and species are endemic to a single biogeographic region (Heptner and Ivanenko 2002; Gollner et al. 2011). The origin of dirivultids is unclear, but migration from other deepsea chemosynthetic habitats (stepping stone hypothesis; Gollner et al. 2010a) or deep-sea sediments seems unlikely, since the Dirivultidae are unknown in these environments. The ancestral dirivultids may have been associated with deep-water invertebrates (Heptner and Ivanenko 2002; Ivanenko and Martinez Arbizu 2016). Evolutionary switching from living in symbiosis to living on bacterial mats of hydrothermal vents is also shown for siphonostomatoid copepods of the genus Collocherides belonging to the symbiotic family 
Asterocheridae, with one species (C. brychius) found on bacterial mats at a deep-water hydrothermal site in the northeastern Pacific and another four congeners living in the gut of shallow-water ophiuroids (Stock 1971; Humes 1999). The Dirivultidae occupies a prominent part of most communities at vents, in particular on sulphide edifices, and is the only invertebrate taxon endemic to hydrothermal vents found in the Atlantic, Pacific and Indian oceans (Gollner et al. 2010a, 2016; Sarrazin et al. 2015). They live on hard substrates and are found on bacterial mats as well as in aggregations of various engineer species (e.g. alvinellids, siboglinids and bivalves). Copepods of the genus Dirivultus differ from most other free-moving dirivultids and are found as parasites attached to the tentacular crown of Riftia (Humes and Dojiri 1980). Other harpacticoid and cyclopoid copepods previously known only from shallow waters (like Tisbe, tegastids and cyclopinids) were reported from hydrothermal vents in the Lucky Strike hydrothermal vent field and later found in other deep-water chemosynthetic environments (Ivanenko and Defaye 2004a, b; Ivanenko et al. 2011a, 2012).

Kinorhynchs are absent at the caldera of the Sulawesi shallow-water hydrothermal vent in the Pacific, but they are present outside the vent influence area (Zeppilli and Danovaro 2009). In the deep sea of the North Fiji Basin in the Pacific Ocean, kinorhynchs were present both in the active hydrothermal sediments and at the control station far away from vent activities (Vanreusel et al. 1997). Kinorhynchs can colonise vent sediments after a catastrophic seafloor eruption (Mullineaux et al. 2012).

While successions of large animals at vents are relatively well known, information on the associated meiofauna is sparse (Gollner et al. 2013). A study of mussel beds of different ages ( 4 to $>20$ years), representing a late successional stage of vent communities, showed that nematodes are less abundant and diverse at younger sites (Copley et al. 2007). Nematodes are negatively impacted by volcanic eruptions and require long time periods to colonise new lava-flooded areas (Gollner et al. 2013). An important aspect of recolonisation by nematodes after a volcanic eruption is linked to the survival of populations in some undisturbed, local patches associated with topographic features (Tsurumi et al. 2003; Gollner et al. 2013). Several experiments were performed on the MAR with paired wood and slate panels deployed at different localities in close proximity to visible hydrothermal activity (Cuvelier et al. 2014; Zeppilli et al. 2015a; Plum et al. 2017). After 1 year, the different types of substrata appeared to attract different nematode and copepod communities (Cuvelier et al. 2014; Zeppilli et al. 2015a), and after 2 years, the type of substratum seemed less important to community structure. Instead, local environmental conditions and hydrothermal activity significantly influenced the composition of nematode and copepod communities independently of the type of substratum (Cuvelier et al. 2014; Plum et al. 2017).
Adaptation of meiofauna to hydrothermal vent conditions

The nematode genus Oncholaimus tolerates extreme geothermal and hypersaline conditions and high sulphide concentrations (Gerlach and Riemann 1973; Thiermann et al. 1994). For example, $O$. campylocercoides in hydrothermal vents of the Aegean Sea, as well as in brackish waters in the Baltic and Black seas (Thiermann et al. 1994, 1997), has been shown to produce sulphur-containing droplets when exposed to hydrogen sulphide (Thiermann et al. 1994), reducing the concentration and toxic effect of hydrogen sulphide The accumulation of elemental sulphur also provides an energetic 'deposit' for later oxidation to thiosulphate, sulphite or sulphate under oxic conditions (Thiermann et al. 2000). In the deep-sea Lucky Strike hydrothermal vent field (MAR), Oncholaimus is very abundant at the most active vent sites (Tchesunov 2015; Zeppilli et al. 2015a). This Oncholaimus species has a detritivore diet with a specialisation on free-living chemoautotroph microorganisms (Zeppilli et al. submitted). This species also harbours an epibiotic microbial community dominated by Gammaproteobacteria lineages, which includes vent symbionts (Zeppilli et al. submitted). The nematode Halomonhystera shows ovoviviparous reproduction near vent emissions at MAR sites (Zeppilli et al. 2015a), as reported in other extreme environments (e.g. cold seeps; Van Gaever et al. 2006).

Dirivultidae copepods possess haemoglobin with a high affinity for oxygen, making them well adapted to lowoxygen habitats (McMullin et al. 2000). They are also characterised by fast movements that can be used to escape extreme vent fluctuations (McMullin et al. 2000). Dirivultid females typically carry only one or two embryos in each of two embryo sacks, and their non-feeding lecithotrophic nauplii develop in the plankton, away from the extreme environment (Ivanenko et al. 2007b, 2011b).

\section{Cold seeps}

Cold seeps are regions of the seafloor where chemicals seep through the oceanic crust (Ritt et al. 2010). Fluids and mud can escape as bubbles, form carbonated structures, brine lakes, mud volcanoes and pockmarks (Levin 2005; Foucher et al. 2009). Like hydrothermal vents, they are characterised by the presence of reduced chemical compounds (hydrogen sulphide, methane and hydrocarbons), local hypoxia or even anoxia, high microbial abundance and metabolic activity, and the production of autochthonous, organic material by chemoautotrophic bacteria. The first cold seep was discovered in 1979 on the active margin of San Clemente in California (USA) (Sibuet and Olu 1998). Since then, other cold seeps have been found on the passive margin of Florida (USA) in the Gulf of Mexico, on the subduction zones of Oregon (USA) 
and Japan, and the Barbados accretionary prism (Juniper and Sibuet 1987; Olu et al. 1996). In Europe, cold seeps have also been found on the Norwegian margin, in the Gulf of Cadiz and the Mediterranean Sea (Vanreusel et al. 2009 and references therein; Ritt et al. 2010; Zeppilli et al. 2011, 2012).

\section{Meiofauna from cold seeps}

Foraminiferans are an important component of meiofauna at seeps worldwide (reviewed by Levin 2005), where they have been studied in part because of their potential as indicators of methane seepage in the palaeoceanographic record (e.g. Rathburn et al. 2003). Foraminiferal densities may be high at some shallow-water seeps (Panieri 2006), but this is generally not the case in deeper water, where seep-associated species are similar to those found in organically enriched, oxygen-depleted settings (Levin 2005). Living benthic foraminifera from modern cold seeps have been investigated in a number of studies (e.g. Sen Gupta and Aharon 1994; Kitazato 1996; Sen Gupta et al. 1997, 2007; Rathburn et al. 2000, 2003; Bernhard et al. 2001, 2010; Torres et al. 2003, 2010; Martin et al. 2004, 2010; Heinz et al. 2005; Panieri 2006; Mackensen et al. 2006; Lobegeier and Sen Gupta 2008; Fontanier et al. $2014 b)$. This work suggests that foraminiferal species observed in cold seep areas are not endemic and may be recruited from adjacent non-seep zones (e.g. Sen Gupta and Aharon 1994; Kitazato 1996; Sen Gupta et al. 1997; Rathburn et al. 2000, 2003; Lobegeier and Sen Gupta 2008; Martin et al. 2010; Fontanier et al. 2014b).

Nematodes dominate the metazoan meiofauna in sediments of deep-sea seeps worldwide (Levin 2005; Van Gaever et al. 2009a; Zeppilli et al. 2011, 2012; Lampadariou et al. 2013). In deep-sea seeps in the Arctic and Atlantic oceans (Van Gaever et al. 2006, 2009a), and in pockmark sediments of the North Sea (Dando et al. 1991), gas emissions cause significant reduction in biodiversity, especially for nematodes. The Håkon Mosby mud volcano was found to be largely dominated by a single species (Halomonhystera sp.), which accounted for up to $98 \%$ of the nematode fauna (Van Gaever et al. 2006). In the Gulf of Guinea, seep sediments yielded low nematode diversities, with only two species (Sabatieria mortenseni and Desmodora sp.) accounting for $70 \%$ of the total nematode abundance (Van Gaever et al. 2009a). Conversely, mud volcanoes and pockmarks in the Mediterranean Sea hosted higher levels of nematode biodiversity when compared with control sediments not influenced by seepage (Zeppilli et al. 2011, 2012). No dominant genera/species were encountered in sediments with the strongest gas emission, suggesting that nematode species composition depends on local environmental conditions, including seepage activity (Zeppilli et al. 2011, 2012).

Copepods are generally the second meiofaunal group in terms of abundance in cold-seep sediments, followed by several temporary groups (Lampadariou et al. 2013). At the
Håkon Mosby mud volcano, many harpacticoid copepods of the genus Tisbe were found (Van Gaever et al. 2006). The poecilostomatoid copepod of the genus Hyphalion living in Calyptogena is found in both cold seeps and hydrothermal vents, like their hosts (Humes 1987). A group of calanoid copepods belonging to the family Spinocalanidae is found in swarms over hydrocarbon seeps of hydrothermal vents and cold seeps (Ivanenko et al. 2007a). Fifty-five copepod species associated with tubeworm and mussel aggregations around a hydrocarbon seep in the Green Canyon of the Gulf of Mexico were identified, most of which were new to science (Plum et al. 2015). At cold seeps, foundation species (such as tubeworms and mussels) may shape the community abundance and composition of associated copepods (Bright et al. 2010; Plum et al. 2015).

Kinorhynchs were identified at the phylum level at several kinds of cold seeps in the Gulf of Mexico, Caribbean Sea, Black Sea, Mediterranean Sea and East Pacific (off Oregon). Specifically, they were reported at deep-water hydrocarbon seeps in microbial mats of Beggiatoa, in fields of the clam Calyptogena and associated with tubeworm and mussel aggregations (Robinson et al. 2004; Sommer et al. 2007; Bright et al. 2010). as well as at shallow-water methane seeps (Revkov and Sergeeva 2004) and deep and shallow mud volcanoes (Olu et al. 1997; Zeppilli et al. 2011; Lampadariou et al. 2013). In addition, Zeppilli et al. (2012) found kinorhynchs in both active and inactive pockmarks. It is noteworthy that, inside the inactive crater, in which nematodes, copepods and polychaetes were abundant, kinorhynchs were the only representative of the 'rare taxa' ( $<1 \%$ of the total meiofaunal abundance; Zeppilli et al. 2012). Currently, a single study focused on kinorhynchs was carried out at gas seeps, specifically in shallow basins with $\mathrm{CO}_{2}$ gas vents (Álvarez-Castillo et al. 2015). This venting activity decreases the pore water $\mathrm{pH}$, causing acidification of the bottom water. At Wagner and Consag basins (Gulf of California), the $\mathrm{pH}$ reaches low values (6.06-7.83) and kinorhynchs occur in a relatively high abundance (2.64\% of the total meiofauna), ranking fourth after nematodes, copepods and polychaetes. The family Pycnophyidae was the best represented in the area, both in total abundance (52.18\%) and richness, and comprised seven out of ten identified morphospecies.

An exceptional abundance of rotifers was found in anoxic and highly sulphidic sediments associated with shallow gas hydrates at the southern crest of Hydrate Ridge off Oregon (USA), NE Pacific (Sommer et al. 2007). Yet, the occurrence of high abundances of rotifers in several marine habitats has been questioned in light of the likely contamination from freshwater (even distilled water) used during the extraction of meiofauna (Funch et al. 1996; Guilini et al. 2012). Ostracods and halacarids were also reported in the hydrocarbon seep, Green Canyon, Gulf of Mexico (Bright et al. 2010). 


\section{Adaptation of meiofauna to cold seep conditions}

Metabolic adaptations (facultative anaerobic metabolism, mutualism with prokaryotes) and habitat and food preferences (elevated epibiotic habitat, bacterivory) may help explain foraminiferal occurrence in methane- and sulphide-enriched sediments (e.g. Bernhard et al. 2001, 2010; Panieri 2006; Mackensen et al. 2006; Sen Gupta et al. 2007; Lobegeier and Sen Gupta 2008). However, in some studies, strong disequilibrium has not been noted between the $\delta^{13} \mathrm{C}$ of living foraminiferal tests from cold seep zones and the expected very low $\delta^{13} \mathrm{C}_{\text {DIC }}$ of hydrate-gas fluid (e.g. Sen Gupta and Aharon 1994; Torres et al. 2003; Bernhard et al. 2010). Therefore, it has been suggested that foraminiferans may calcify during periods of low methane discharge or during intermittent episodes of seawater flow into sediments (Torres et al. 2003). In addition, foraminiferal $\delta^{13} \mathrm{C}$ signatures may also reflect the ${ }^{13} \mathrm{C}$-depleted food source (e.g. methanotroph bacterial biomass) and/or prokaryotic symbionts (Sen Gupta and Aharon 1994; Rathburn et al. 2003; Panieri 2006; Mackensen et al. 2006; Bernhard et al. 2010). Accordingly, Panieri (2006) documented lighter protoplasmic $\delta^{13} \mathrm{C}$ for foraminiferans living in hydrocarbon seeps compared to an adjacent non-seep area, suggesting that Beggiatoa (prokaryotes) may be a food source for the foraminiferans.

Nematodes are adapted to cold-seep environments and appear to tolerate their extreme environmental conditions, which include reduced oxygen availability and, in some cases, very high hydrogen sulphide concentrations (Zeppilli et al. 2012). They have developed special physical characteristics, including a longer and thinner body shape, which seems favourable for life in thiobiotic conditions (Lampadariou et al. 2013). Sediment bioturbation by macrofauna creates oxygen islands, where meiofaunal organisms can seek refuge (Ritt et al. 2010). Furthermore, as observed for vent environments, Halomonhystera shows ovoviviparous reproduction (Van Gaever et al. 2006).

\section{Carcasses and sunken wood}

Cetacean carcasses and sunken wood that fall to the ocean floor represent an important source of organic matter for the oligotrophic deep-sea benthos (Debenham et al. 2004). The sulphur production induced by the carcass degradation supports a rich fauna of chemoautotrophic organisms (Smith and Baco 2003). This temporary environment sustains a chemosynthetic community for up to 10 years (Pavlyuk et al. 2009) and can support ecosystems that extend up to $30 \mathrm{~m}$ in diameter (Debenham et al. 2004). Initially, the carcass is colonised by necrophagous organisms and successively by scavengers that consume the soft tissue of the cetaceans, followed by opportunistic species with different feeding modes (Smith and Baco
2003; Lundsten et al. 2010). Bones are then colonised by microorganisms or chemoautotrophs using sulphur as respiratory metabolites (Smith and Baco 2003; Fujiwara et al. 2007), as well as by specialised bone-eating polychaetes of the genus Osedax (Rouse et al. 2004) and, finally, by suspension feeders. Sunken wood is widely distributed in the oceans and constitutes a microhabitat suitable for sulphide-oxidising symbioses due to the sulphides produced from the decomposition of the wood in seawater (Laurent et al. 2009; Bienhold et al. 2013).

\section{Meiofauna from carcasses and sunken woods}

In shallow-water ecosystems, nematode abundance and diversity are negatively affected by the presence of a whale carcass (Pavlyuk et al. 2009). Similarly, the abundance and diversity of meiofauna under an estuarine stingray carcass were significantly lower when compared with samples away from the carcass (Fonseca et al. 2011). Only a few nematode species, typical of hypoxic/anoxic sediments, were more abundant under this carcass (Fonseca et al. 2011). Among copepods associated with sunken wood, Xylora bathyalis is also found living in hydrothermal vents and cold seeps (Hicks 1988; Cuvelier et al. 2014; Plum et al. 2015). Copepods living on carcasses are poorly studied. Naupliar and copepodid stages of the harpacticoid copepod Tegastes satyrus (family Tegastidae) were found on filamentous bacteria-covered whale bones developed on carcass deployed near the coast of Sweden (Willems et al. 2009).

Wood falls and whale carcasses have been considered as evolutionary stepping stones for the colonisation of chemosynthetic environments (Smith and Baco 2003; Bienhold et al. 2013; Cuvelier et al. 2014; Zeppilli et al. 2015a). In a colonisation experiment using wood and slate substrata at the Lucky Strike hydrothermal vent field, the opportunistic nematode Halomonhystera showed a preference for wood, indicating the tolerance of this species to low oxygen and high sulphide concentrations, and a possible link with the sulphide production due to wood decomposition (Cuvelier et al. 2014).

\section{Deep sea}

The deep sea, the largest ecosystem on Earth, is considered to be extreme due to the high pressure, low temperature, generally low food input and lack of light (Gage and Tyler 1991; Mestre et al. 2014). Deep-sea habitats represent the most common environmental conditions on our planet, as they cover $66 \%$ of the Earth's surface: the fact that they are defined as 'extreme habitats' only reflects our biased knowledge on biodiversity, based mostly on terrestrial and marine coastal habitats. The deep sea is inhabited by benthic communities with unique characteristics (Ramirez-Llodra et al. 2010). One key 
ecological attribute of this vast habitat is food limitation (Smith et al. 2008), at least for the abyssal plains, which occupy the largest part of the deep-sea floor. This leads to a general decrease in body size and an increase in the relative abundance of small organisms (meiofauna) (Rex et al. 2006). Favoured by the prevailing low and constant temperatures, some deep-sea taxa (e.g. fish) grow slowly and have a long life span with low maintenance expenditure (Seibel and Drazen 2007; Giere 2009). A number of distinct habitats can be identified in the deep sea, and each of them is characterised by a number of unique features, which, in turn, define the biological communities that inhabit them. Rosli et al. (this issue) provide a comprehensive review of ecological studies of deep-sea meiofauna, and Zeppilli et al. (2015b) reviewed cobalt-rich ferromanganese crusts and polymetallic nodule habitats. After a review of chemosynthetic environments, including deep-sea vents, seeps and organic falls, and in order to avoid treating the most common habitat of the planet as an unusual one, here, we focus only on three deep-sea ecosystems that represent peculiar and potentially true extreme habitats: canyons, deep hypersaline anoxic basins (DHABs) and hadal zones.

\section{Deep sea: canyons}

Submarine canyons are deep, narrow indentures of continental shelves and slopes and oceanic islands, forming a direct pathway from shallow water to the deep sea (defined by Shepard 1972). They comprise complex, highly heterogeneous environments with rugged topography that encompasses a patchwork of habitats with different degrees of stability and organic enrichment (Tyler et al. 2009; Amaro et al. 2016). All canyons are different. Some are more active than others, but many are subject to enhanced current activity and physical disturbance, particularly in the upper and middle sections of canyons (de Stigter et al. 2007), whilst deeper sections are usually less disturbed but can experience irregular sediment disturbances originating from shallower sections of the canyon. Sediment slumps and slides may occur on steep slopes, while gravity flows and turbidity currents can erode the seabed in the upper parts of active canyons, as well as rapidly depositing sediment layers in the lower reaches. The instability and physical disturbance characteristic of many canyon environments means that the benthic faunas occupying them are often exposed to severe physical disturbance. Turbidity currents are common in active canyons and can be triggered by events such as storms, flood discharges, seismic activity, dense shelf water cascading and sediment slumping (Bolliet et al. 2014) or even anthropogenic activities on canyon interfluves such as trawling (Puig et al. 2012). To a large extent, turbidity currents affect the communities in their path by eroding the canyon floor as well as through the rapid deposition of a new layer of sediment.
Whilst each canyon has unique morphological, hydrographic, sedimentological and biological properties, a significant feature linking them is high heterogeneity in habitat characteristics. This heterogeneity is expressed at different spatial and temporal scales, as one might expect, given the range of temporally and spatially different types of disturbances that have been documented in submarine canyons. Studies of meiofauna in submarine canyons systems have seen a significant rise in the past couple of decades, whilst before that, the interstitial component of canyon benthos was often ignored. From an ecological perspective, however, submarine canyons provide ideal settings to assess the roles of environmental drivers and disturbance regimes on meiofaunal communities.

\section{Meiofauna from canyons}

\section{Foraminifera}

Jorissen et al. (1994) reported that live benthic foraminiferans were scarce or absent in three cores obtained during submersible dives in three separate canyons (Wilmington, Wilmington South and South Heyes) on the New Jersey margin. They attributed the absence of stained foraminiferans in the South Wilmington sample to a strong current that was observed eroding the seabed during the dive, and the occurrence of unusually sparse populations confined to the $0-1-\mathrm{cm}$ layer of the Wilmington and South Heyes cores to mass wasting events (sediment slumping). Stained foraminiferans were more abundant, and penetrated deeper into the sediment, in two other cores from an apparently more quiescent part of the Wilmington canyon, although densities were still lower than those in samples from the similar depths outside the canyons.

A series of studies in the Cap Breton Canyon in the southern Bay of Biscay has revealed different stages in the recovery of foraminiferal assemblages from the turbidite currents that have caused frequent disturbances in this active canyon. One such event, triggered by a severe storm in December 1999, killed foraminiferal assemblages by burying them under a turbidite layer. Samples taken 4 months later (May 2000) in the middle part of the canyon (647 $\mathrm{m}$ depth) documented the initial recolonisation of this 18 -cm-thick deposit by pioneer foraminiferans largely confined to the upper $1-\mathrm{cm}$ layer of sediment and dominated by a normally rare species, Technitella melo (Anschutz et al. 2002; Hess et al. 2005). This species is also recorded by Duros et al. (2017) at two deeper sites (983 and $1478 \mathrm{~m}$ ) in the canyon axis together with Fursenkoina bradyi and Reophax dentaliniformis, these three species being regarded by the authors as the first recolonisers of turbidite deposits. A later successional stage was represented at the 650-m site in June and September 2001, more than 1.5 years after the 1999 turbidity current, by higher density assemblages that penetrated more deeply into the sediment 
and were dominated (80-86\%) by Bolivina subaenariensis (Hess et al. 2005). Again, Duros et al. (2017) reported a similar assemblage at other sites in the Cap Breton Canyon. By 2005, the $650-\mathrm{m}$ site in the canyon axis sampled by Hess and Jorissen (2009) had been covered by a new 5-cm-thick turbidite layer that had been colonised afresh by foraminiferans (Bolliet et al. 2014). Rather surprisingly, T. melo was entirely absent and the dominant species was again $B$. subaenariensis. The reduced faunal densities and somewhat higher diversity compared with 2001 suggested that the recolonisation was more advanced. Elsewhere, in places not impacted by recent turbidity flows, foraminiferal assemblages either appear to be more typical of undisturbed habitats on the slope outside the canyon (Duros et al. 2017) or possibly represent later successional stages (Hess and Jorissen 2009; Bolliet et al. 2014). Taken together, these studies suggest that foraminiferal communities in the axis of the Cap Breton Canyon are repeatedly disturbed or destroyed by turbidity currents, leading to a patchwork of assemblages at different successional stages, while those inhabiting the more tranquil and organic-rich canyon flanks (terraces) enjoy greater stability.

There is evidence for similar processes occurring in other canyons. The Nazare Canyon on the Portuguese margin is highly active, with evidence for strong tide-generated currents, high levels of suspended material in the water column and regular turbidity current activity (Tyler et al. 2009). Koho et al. (2007) found differences between foraminiferal assemblages at similar depths in the canyon axis and on the adjoining terrace. As in the Cap Breton Canyon, terrace sites yielded relatively diverse and high density assemblages, reflecting their relative tranquillity, whereas low abundance, low diversity assemblages characterised the axis sites, reflecting their physical instability. A sample from $1118 \mathrm{~m}$ in the canyon axis, however, yielded an anomalously high abundance of stained foraminiferans dominated $(75 \%)$ by Technitella melo, one of the first recolonisers of the 1999 Cap Breton Canyon turbidite. At this depth, the Nazare Canyon appears to be subject to turbidity flows on a fairly regular basis. Species of Technitella are also recorded from submarine canyons off New Jersey (Swallow and Culver 1999). On the other hand, pioneer assemblages of foraminiferans typical of sediments deposited by recent turbidites are not reported from the Whittard Canyon (Duros et al. 2011, 2012), which appears to be less active than the Cap Breton and Nazare canyons (Amaro et al. 2016).

Meiofaunal assemblages are influenced by enhanced current flow in other deep-sea settings. The HEBBLE area, located $\sim 4820 \mathrm{~m}$ on the lower continental rise off Nova Scotia, is the best known example. Here, the seafloor is periodically disturbed by periods ('benthic storms') during which current flow is elevated to speeds of $\sim 40 \mathrm{~cm} \mathrm{~s}^{-1}$ (Richardson et al. 1981). Kaminski (1985) recognised two foraminiferal assemblages in this area, both of which exhibited depressed diversity compared to a relatively tranquil control site (HEBBLE Shallow Site, $4185 \mathrm{~m}$ depth). The genus Psammosphera and other robust, coarsely agglutinated foraminiferans (species of Ammobaculites, Reophax and Saccammina) were dominant elements in the HEBBLE assemblages in contrast to the greater prevalence of more delicate multi-chambered taxa and komokiaceans in typical tranquil abyssal habitats. Kaminski (1985) interpreted the fauna from a HEBBLE box core that displayed clear evidence of recent disturbance by a benthic storm as being at an early stage of recolonisation, with other samples collected during the following year representing a somewhat later successional stage. Similar assemblages, albeit involving different foraminiferal taxa, are known from shallower depths $(2500-4000 \mathrm{~m})$ under the Western Boundary undercurrent, also in the NW Atlantic (Kaminski and Schröder 1987). Ecological processes in response to the elevated currents in the HEBBLE and other hydrodynamically disturbed areas therefore appear somewhat comparable to those occurring within active canyons.

\section{Metazoan meiofauna}

Since the 1990s, more than 30 publications have focused on meiofauna in submarine canyons. Many of these studies have concentrated on one or multiple canyon systems as part of larger multi-disciplinary studies; these include canyons in the NE Atlantic (e.g. Nazare, Setubal, Cascais, Whittard, Baltimore and Norfolk), Mediterranean (Blanes, Bari and Gulf of Lions) and the Kaikoura Canyon in the Southwest Pacific, among others. The advantage of studying meiofauna in conjunction with other oceanographic and marine biological disciplines is the ability to link the observed patterns to environmental conditions and ecological relations with other benthic or pelagic biotic components and oceanographic, biogeochemical and anthropogenic phenomena, such as dense water shelf cascading, trawling, sediment turbidity and deposition regimes, and hydrodynamics (e.g. Amaro et al. 2016).

There is a general consensus that submarine canyons provide suitable habitats to support enhanced meiofauna abundance and biomass compared to other deep-sea habitats; indeed, they are often claimed to be abundance and biomass 'hotspots' (De Leo et al. 2010; Vetter et al. 2010; Amaro et al. 2016). Reasons for enhanced abundance and biomass in submarine canyons are generally ascribed to increased organic matter input in canyons, whether from favourable surface water conditions supporting increased primary production over the canyon area, topographic entrapment and channelling leading to accumulation in the canyon, or terrestrial and riverine inputs, and even anthropogenic activity such as trawling leading to sediment failure and resuspension events. These processes act in concert to produce canyon sediments that are usually richer in organic matter (labile or refractory, depending on the active processes) compared to 
adjacent slope environments, although spatial and temporal changes can cause significant variability. The often high amounts of food (but not necessarily high quality/ availability; see Kiriakoulakis et al. 2011) enriches the sedimentary standing stock, and disturbance regimes stimulate recolonisation processes on a regular basis, allowing biodiversity enrichment, at least for meiofauna (Snelgrove and Smith 2002; Ingels et al. 2011c; Ingels and Vanreusel 2013). Whilst much of the literature supports the claim of canyons being meiofauna abundance 'hotspots', many studies also offer the view that meiofauna abundance in canyons can be extremely variable, with meiofauna densities ranging anywhere between 3 and 9457 ind. $10 \mathrm{~cm}^{-2}$ (values from the Congo Channel and head of the Mississippi Trough, respectively; Baguley et al. 2006; Van Gaever et al. 2009b). de Bovée et al. (1990), for instance, reported 2-3-fold abundance variations for similar depths and 10-15-fold variation in meiofauna abundance along the entire depth range studied in the Gulf of Lions; even twin branches or areas within the same canyon branch can exhibit large abundance variation (Bianchelli et al. 2008; Ingels et al. 2009, 2011a).

At the same time, the unique canyon characteristics support an equally unique meiofauna, with a number of taxa that are regularly found inside the canyon not being observed in the adjacent slope sediments. For instance, Bianchelli et al. (2010) reported several taxa that either lived exclusively in canyons (including tanaids, echinoid larvae) or exclusively on the adjacent slopes (priapulids, holothuroids, ascidiaceans, cnidarians) in their large-scale study on six canyon systems from three different deep-sea regions. These results argue for the importance of topographic features in the distribution of rare meiofauna taxa in the deep sea, but also highlight the importance of biodiversity turnover along continental margins and the contributions that canyons make to regional diversity. Whilst canyon local or alpha biodiversity is often lower than for adjacent slope areas [but there are exceptions; see Ingels et al. (2011c) for the Whittard Canyon and Gollum Channels], high biodiversity turnover rates (beta diversity) have been observed between canyon areas and adjacent non-canyon areas in several studies, implying that canyon biodiversity contributes significantly to total regional or margin biodiversity (Danovaro et al. 2009; Ingels et al. 2011a; Leduc et al. 2014). The fact that different meiofauna communities can be found in canyons compared to slope systems attests to the observation that canyons contribute to regional diversity (Danovaro et al. 2009, 2010a).

Canyon systems are complex environments, and their faunas are influenced by multiple factors, which include hydrodynamic conditions and current regimes, topography and habitat heterogeneity, terrestrial and riverine input, surface productivity, sedimentation processes and turbidity events, anthropogenic activities etc. (Danovaro et al. 1999; Baguley et al. 2006; Ingels et al. 2009, 2011c, 2013; Ramalho et al.
2014; Amaro et al. 2016; Román et al. 2016; Thistle et al. 2017). The general bathymetric decline of abundance and biomass, as often observed on continental slopes, is nearly always interrupted in submarine canyons, owing to the great heterogeneity within each canyon [although exceptions can be found, e.g. Ardencaple Canyon in the Arctic (Soltwedel et al. 2005) and Gulf of Lions (Grémare et al. 2002)], differences in nearshore input of organic matter (Baguley et al. 2006) and organic carbon influx and accumulation (Soetaert et al. 1991; Danovaro et al. 1999, 2010a; Román et al. 2016), and bottom currents and sediment disturbance (Romano et al. 2013), among others. In addition, inter- and intra-annual variations in environmental conditions are known to influence meiofauna abundance, biomass and diversity, adding temporal complexity to bathymetric patterns in canyon systems (Ingels et al. 2013; Romano et al. 2013; Ramalho et al. 2014; Román et al. 2016).

In the Blanes Canyon, for instance, the bathymetric abundance decline that was present in autumn 2003 disappeared in the following spring, when storm-induced current speeds and influx of refractory material increased (Romano et al. 2013). Such seasonal alterations also have an effect on the size of meiofauna organisms, either through food-induced replacement of taxa or food-induced transition from a 'latent' to a 'reproductive' community with more juvenile specimens (Ingels et al. 2013). At the same time, however, inter-annual variations occur, and these are also important in driving meiofauna assemblages in canyons, but they can be overridden by variability caused by habitat heterogeneity and water depth differences, which, in turn, may influence food supply and availability (Ramalho et al. 2014).

\section{Adaptation of meiofauna to canyon conditions}

Hydrodynamic disturbance is a factor often used to explain reduced meiofauna abundance and biomass sometimes found in canyons and channel systems. In the Nazare Canyon, Garcia et al. (2007) attributed extremely low meiofauna abundance (as low as 5.9 ind. $10 \mathrm{~cm}^{-2}$ ) in the canyon axis mainly to the high-velocity bottom currents and unstable sedimentary conditions, particularly in the upper- and mid-canyon regions. In the Congo Channel, the active system with high-speed currents resulted in meiofauna abundances as low as 3 ind. $10 \mathrm{~cm}^{-2}$ (Van Gaever et al. 2009b). Other explanations for reduced abundance and biomass may be high levels of sedimentation and burial, leading to oxygen stress. For meiofauna communities, however, such disturbance often leads to replacement with opportunistic taxa or more specialised taxa, rather than a reduction of total meiofauna (Ingels et al. 2009). In this context, the observed dominance of nematode genera, such as Sabatieria, has often been linked to oxygen stress and sediment disturbance in general (Garcia et al. 2007; Schratzberger et al. 2009; Leduc et al. 2014), whilst the 
presence of Microlaimus, for instance, can indicate sediment disturbance and recolonisation processes (Lee et al. 2001; Van Gaever et al. 2009b; Leduc et al. 2014).

Several authors have claimed that canyons are harsh environments and that only opportunistic organisms can survive in these habitats (e.g. Garcia et al. 2007), but more detailed studies that include different types of canyon environments, such as the axis, terraces, gullies, levees and the sloping walls of interfluvial areas, indicate that there is a diverse range of conditions with variable meiofauna communities inhabiting them. To gain more information on the lifestyle and functional attributes of meiofauna organisms in canyon systems, several authors have looked at life-history aspects and trophic diversity of nematodes (Ingels et al. 2011a, b; Ingels and Vanreusel 2013; Gambi and Danovaro 2016). Gambi and Danovaro (2016) found a general dominance of deposit feeders in the Whittard Canyon, as also found by Ingels et al. (2011c) and Amaro et al. (2016). Canyon sediments are also generally characterised by a more complex nematode trophic complexity compared to slope systems, with a more even distribution between the different feeding types, a likely consequence of the greater variety of food sources available in canyon sediments and enhanced niche exploitation (Ingels et al. 2011b). Amaro et al. (2016) and Gambi and Danovaro (2016) also show that predatory species are less prevalent in the Whittard Canyon than on the adjacent slope, although it has been shown for the Nazare Canyon that predatory and scavenging species can be more abundant and can represent greater biomass in the canyon compared to the slope (Ingels et al. 2009, 2011b). Local conditions and environmental heterogeneities on a $\mathrm{cm}$ or $\mathrm{mm}$ scale are likely the cause for such discrepancies since canyon nematode communities tend to be regulated by processes that operate on very small spatial scales (Ingels and Vanreusel 2013; Rosli et al. this issue). In the same context, the prevalence of opportunistic nematode taxa in canyons stands in contrast with the relatively more persistent taxa and communities characteristically found in slope environments, a consequence of the regular sedimentary disturbances and environmental variability in canyon sediments. A major implication of these functional studies is that different deep-sea habitats can be associated to different life strategies and taxa with different functional attributes and contribute to increase the functional diversity of deep-sea ecosystems (Ingels et al. 2011b; Gambi and Danovaro 2016).

One notable observation in recent canyon meiofauna studies has been the recurrence of the chemotrophic nematode genus Astomonema, which lacks a mouth and has a reduced digestive system, whilst it hosts endosymbiotic, thiotrophic bacteria (Ott et al. 1982; Vidakovic and Boucher 1987; Dando et al. 1991; Austen et al. 1993; Giere et al. 1995). So far, it has been identified in canyon systems in the NE and NW Atlantic (Baltimore and Norfolk canyons, Nazare, Setubal and Cascais canyons, Whittard Canyon and Gollum Channels) and the Mediterranean (Blanes Canyon) (Ingels et al. 2009, 2011a, c; Tchesunov et al. 2012; Ingels, unpublished data; Roman, unpublished data). This genus is usually associated with shallow-water, reduced sediments, where it feeds on the internal symbiotic bacteria (sulphide oxidisers) that themselves feed on sulphides from the hypoxic/anoxic sediments. At the canyon locations where Astomonema has been found, researchers have usually observed high sediment deposition rates, likely resulting in organic matter burial and relatively rapid development of anoxic conditions (Ingels et al. 2011c). This is yet another feature of canyon systems: sedimentary deposition centres that may lead to the development of a chemotrophic contribution to a traditionally heterotrophic benthic food web.

\section{Deep sea: hypersaline anoxic basins}

DHABs are deep-sea extreme environments characterised by anoxic and hypersaline seawater. After their discovery in the eastern Mediterranean Sea in the 1990s, several DHABs were reported in other locations of the Mediterranean Sea and the Red Sea (Edgcomb et al. 2009). DHABs were formed 5 million years ago when, caused by tectonic plate movements, salt deposits from the Miocene inside the sediment were released, followed by a salt enrichment of the bottom water (Edgcomb et al. 2009).

\section{Meiofauna from deep hypersaline anoxic basins}

Several meiofaunal groups such as nematodes, loriciferans and copepods have been retrieved dead from Mediterranean DHABs (e.g. L'Atalante Basin; Bernhard et al. 2015), but only three species of loriciferans (belonging to the genera Rugiloricus, Pliciloricus and Spinoloricus, respectively) were found alive and in relatively high abundance (Danovaro et al. 2010b, 2016).

\section{Adaptation of meiofauna to deep hypersaline anoxic basin conditions}

Loriciferan species appear to lack mitochondria, but, rather, possess hydrogenosomes and symbiotic sulphur bacteria. A new loriciferan species, Spinoloricus cinziae, which is adapted to the high osmotic pressure ( $>200$ bar) and able to live permanently in habitats lacking molecular oxygen, was recently described from the L'Atalante Basin (Neves et al. 2014).

\section{Deep sea: hadal environments}

The hadal zone extends from $6500 \mathrm{~m}$ down to almost $11,000 \mathrm{~m}$ depth and accounts for nearly half of the ocean's 
depth range (UNESCO 2009; Watling et al. 2013). Using this definition, a total of 46 individual hadal habitats, including 33 trenches (elongated basins formed by tectonic subduction or fault) and 13 troughs (basins within an abyssal plain not formed at converging plate boundaries), have been identified worldwide with a combined surface area of $800,500 \mathrm{~km}^{2}$, $<1 \%$ of the global seabed area (Jamieson 2015). Hadal environments are typically characterised by temperatures ranging from 1 to $4{ }^{\circ} \mathrm{C}$, with limited within-trench variability $\left(1-2{ }^{\circ} \mathrm{C}\right)$, even in trenches deeper than 10,000 m (Jamieson et al. 2010). Pressure increases by 1 atmosphere (atm) every $10 \mathrm{~m}$ depth, and, thus, increases from $650 \mathrm{~atm}$ to $6500 \mathrm{~m}$ up to a maximum of $1100 \mathrm{~atm}$ in the Challenger Deep (Mariana Trench), the world's deepest point; this corresponds to an approximate two-fold increase in pressure over a 4500-m depth difference. Whilst this difference may seem substantial, a two-fold increase in pressure can occur over much narrower depth differentials in continental slope environments; for example, pressure doubles as one moves from 500 to $1000 \mathrm{~m}$ depth on the continental slope, only a 500-m depth difference. The combination of low temperature and high pressure in the deep sea enhances carbonate solubility and all hadal environments, therefore, lie below the carbonate compensation depth (CCD, generally between 3000 and $5000 \mathrm{~m}$, depending on location), the depth at which no calcium carbonate can accumulate. Hadal trenches are characterised by environmental conditions not found in any other deep-sea environment, thereby providing opportunities to understand the processes that shape benthic communities. The characterisation of bathymetric trends in benthic community abundance and diversity, for example, have mostly been restricted to bathyal and abyssal depths, thus only spanning the upper half of the full ocean depth range. As more studies include hadal environments, these may provide new insights into the factors shaping large-scale patterns of benthic communities in the deep sea and modify existing ecological paradigms. Meiofauna are ideally suited for this kind of investigation because, unlike macrofauna, they are common at all water depths.

The low food supply that characterises deep-sea ecosystems is believed to favour small organisms with low energy requirements over larger organisms with relatively high energy requirements (Thiel 1975, 1979; Rex et al. 2006). Food supply in hadal environments is not considered to be lower than in abyssal environments. Several studies have shown that food availability is higher in the deepest parts of hadal trenches than in nearby trench edge environments, suggesting that the topography of trenches act to concentrate food particles along the trench axis (Glud et al. 2013; Leduc et al. 2016). However, food availability can vary substantially, both among trenches as a result of differences in surface primary productivity and within trenches as a result of water depth gradients, local topography and lateral transport triggered by seismic- induced landslides and turbidity currents (Ichino et al. 2015; Jamieson 2015).

Trenches are probably among the most physically disturbed deep-sea habitats due to the frequent occurrence of turbidity flows and landslides resulting from the combination of seismic activity and steep topography (Blumberg et al. 2008; Ikehara et al. 2016). Thus, whilst food supply may not be as limiting as on the abyssal plain, it is likely to be highly patchy both temporally and spatially. Short-term variation in environmental conditions is likely to be limited in hadal trenches, with the exception of the above-mentioned turbidite and landslide events. Although turbidites do not occur often relative to the lifespan of meiofaunal organisms, their effects are felt over very large areas and are thought to be long lasting (Levin et al. 2001; Lambshead et al. 2001). The physical disturbance created by these events may be a major factor influencing the structure of meiofaunal communities (Kitahashi et al. 2016), through transport and burial of both the meiofauna and their food resources (Nomaki et al. 2016; Leduc et al. 2016).

\section{Meiofauna from hadal environments}

\section{Foraminifera}

A density of 449 living individuals per $10 \mathrm{~cm}^{-2}$ was recorded in the top centimetre of sediments of the Challenger Deep in the Mariana Trench (Todo et al. 2005), which is similar to densities observed in the Japan and Kuril-Kamchatka trenches and greater than on the adjacent abyssal plain (Jamieson 2015). More than 100 species have been identified in samples from hadal depths (Belyaev 1989; Jamieson 2015). Although occasional calcareous tests have been found below $6500 \mathrm{~m}$ depth (e.g. Smith 1973; Khusid 1979), the majority of foraminiferal species recorded from hadal settings are agglutinated. However, recent studies in the Challenger Deep $(10,895 \mathrm{~m}$ depth in the Mariana Trench) have revealed that tiny species belonging to an unusual group of organic-walled genera (Nodellum, Resigella and Conicotheca) overwhelmingly dominate the foraminiferal assemblages in 32- $\mu \mathrm{m}$ sieve fractions (Todo et al. 2005; Gooday et al. 2008a). Why this enigmatic group, which is distinct from other organic-walled foraminiferans in terms of test morphology and wall structure (Gooday et al. 2008a, b), should be so abundant at this extreme hadal site is unclear. The same three genera are common at $4300 \mathrm{~m}$ depth under permanent sea ice at the North Pole (Gooday et al. 2010b), so it could reflect the relatively oligotrophic environment of the Mariana Trench (Gooday et al. 2008a). However, similar taxa are also common at $7800 \mathrm{~m}$ depth in the Peru-Chile Trench, where conditions are much more eutrophic (Sabbatini et al. 
2002). Possibly, the Nodellum group is particularly well adapted to tolerate extreme pressures and benefits from the scarcity of foraminiferal competitors. These taxa are not recorded from the Kuril-Kamchatka or Kermadec trenches (Saidova 1970, 1975), but this could reflect the use of a sieve mesh that was too coarse to retain these tiny species.

Agglutinated species, mainly hormosinaceans, trochamminaceans and fragmentary tubes, occur in the Challenger Deep but are less common, at least in the finer size fractions, than Nodellum and similar genera (Akimoto et al. 2001; Kitazato et al. 2009; Gooday et al. 2010a). In addition to meiofaunal-sized species, giant agglutinated foraminiferans (xenophyophores) are dominant megafaunal organisms visible in video recordings from this extreme depth (Gallo et al. 2015) and are also numerous in seafloor photographs from the New Britain, North Solomon and New Hebrides trenches (7057-8662 m depth) (Lemche et al. 1976).

\section{Metazoan meiofauna}

The abundance of trench metazoan meiofauna ranges from less than 100 ind. $10 \mathrm{~cm}^{-2}$ to almost 1000 ind. $10 \mathrm{~cm}^{-2}$, whilst biomass is usually on the order of 10 to $100 \mu \mathrm{gDW} 10 \mathrm{~cm}^{-2}$ (Leduc et al. 2016); these values are broadly similar to values from abyssal environments (Schmidt and Martínez Arbizu 2015). A notable exception comes from a study of the PeruChile Trench, which yielded a mean meiofaunal abundance of about 6400 ind. $10 \mathrm{~cm}^{-2}$ and biomass of $1800 \mu \mathrm{gDW} 10 \mathrm{~cm}^{-2}$ at $7800 \mathrm{~m}$ depth (Danovaro et al. 2002). Meiofaunal biomass in the Kuril Trench is also somewhat elevated compared to most other trenches, with biomass exceeding $400 \mu \mathrm{gDW}$ $10 \mathrm{~cm}^{-2}$ at $7000 \mathrm{~m}$ depth (Itoh et al. 2011). This contrast in meiofaunal biomass is consistent with differences in regional productivity regimes, estimated particulate organic matter flux to the seabed and variability in food availability in the sediments among these trenches (Jamieson 2015). A number of early and recent studies have shown a negative relationship between depth and the diversity of benthic organisms within trenches (Belyaev 1972; Fujii et al. 2013). Similar patterns have been observed for nematodes (Tietjen 1989; Gambi et al. 2003; Leduc et al. 2016) and harpacticoid copepods (Kitahashi et al. 2013). These trends are often ascribed to shifts in food availability, but the evidence is equivocal and other factors such as the physical characteristics of the sediment, disturbance and larger-scale evolutionary factors may also be important (Kitahashi et al. 2013; Gambi et al. 2003; Leduc et al. 2016). The small size of trench habitats relative to the surrounding abyssal plains, as well as their geographical isolation, may limit both the size of species pools and connectivity among trenches, and may account for the limited diversity observed particularly in the deepest parts of trenches (Jamieson 2015). Analyses of global datasets show that metazoan meiofauna biomass exceeds that of macrofauna below depths of $4000 \mathrm{~m}$ (Wei et al. 2010) and, not surprisingly, meiofauna are by far the most abundant component of sediment communities in trenches.

Deep-sea kinorhynchs are largely unknown compared to the 250 species recorded from relatively shallow waters. Unidentified kinorhynchs have been reported in a few studies from Indian and Pacific Ocean, whereas Atlantic records are more numerous (Neuhaus 2013; Shimanaga et al. 2000; Carman et al. 2004). The deepest recorded specimen, identified only to the phylum level, was found at $7800 \mathrm{~m}$ in the Atacama Trench (Danovaro et al. 2002). In this area, the density of the phylum is around $40-46$ ind. $10 \mathrm{~cm}^{-2}$ and the animals tend to dwarfism, with a size reduction of $60 \%$. However, a specimen of the kinorhynch genus Echinoderes was found at $9000 \mathrm{~m}$ depth in the Kermadec Trench (D. Leduc, unpublished data). The deepest recorded specimens identified to the species level all originate from the abyssal zone: Cristaphyes abyssorum $(5766 \mathrm{~m})$ and Condyloderes kurilensis $(5222 \mathrm{~m})$ from the Kuril-Kamchatka Trench (Adrianov and Maiorova 2015, 2016); Cristaphyes nubilis, Krakenella farinellii (Sánchez et al. 2014a) and Mixtophyes abyssalis (Sánchez et al. 2014b), collected from the Guinea Basin (5136-5174 m), and, finally, Campyloderes cf. vanhöfeni recorded in the Canary Islands $(5055,5102$ and $5118 \mathrm{~m})$ and also in the Guinea Basin (5064 m) (Neuhaus and Sørenson 2013). The discovery of one of these species, Mixtophyes abyssalis, also prompted the description of the new allomalorhagid genus Mixtophyes, one of the most recently described kinorhynch genera.

\section{Adaptation of meiofauna to hadal conditions}

It has been suggested that the dominance of meiofaunal taxa in the deep sea is related to their ability to feed more efficiently on scarce food resources than larger taxa (Thistle 2001). Meiofauna-sized organisms could, thus, be considered as being preadapted to environmental conditions at extreme depths. Nematode and copepod genera and families inhabiting hadal trenches are also found in a wide range of other deep-sea and even shallow-water ecosystems, perhaps indicating that only relatively minor adaptations are required for survival in hadal environments (Tietjen 1989; Gambi et al. 2003; Kitahashi et al. 2012, 2013).

The Challenger Deep, the deepest point of the world's oceans, is thought to have developed gradually over a period of several million years (Fujioka et al. 2002), giving meiofaunal organisms living on what was originally an abyssal seafloor time to adjust to the steadily increasing hydrostatic pressure. Other meiofaunal species in other trenches may have experienced a similarly gradual 
introduction to the hadal environment. However, we currently have little understanding of the nature of the physiological adaptations of meiofauna to the extreme high pressures found in trench environments or to the low temperatures that characterise deep-sea environments generally. Some adaptations described in fish and invertebrate species of trench habitats include an increased proportion of unsaturated fatty acids in cell membrane phospholipids and the production of intracellular protein-stabilising osmolytes (Hazel and Williams 1990; Yancey et al. 2014). Similar adaptations are likely to be present in meiofaunal organisms, but other mechanisms may be involved as well, which could help explain why meiofaunal taxa are so much more successful in these extreme environments than larger organisms. There are many questions remaining to be addressed concerning the biology and ecology of meiofauna living at these extreme water depths. Future studies should aim to describe the role of physical disturbance in shaping meiofaunal abundance and diversity patterns. Some understanding of how factors such as evolutionary history linked to tectonic processes and geographical isolation help to shape diversity patterns is also needed. Progress on these and other fronts will require data on the distribution of meiofaunal species across trenches, as well as insights into genetic connectivity (e.g. Ritchie et al. 2017).

\section{Conclusion and perspectives}

With $90 \%$ of marine environments considered extreme for life, marine extreme environments cover more than half of the Earth's surface (Fig. 4). For example, the deep sea, the planet's largest habitat, only a few decades ago was considered one of the least favourable habitats for life (Gage and Tyler 1991). Yet, in this review, we show that not only the deep sea but even the most extreme marine environments host abundant, often endemic, and well-adapted meiofaunal communities. These communities are sometimes associated with ephemeral and unstable ecosystems. The effects of short-term fluctuations in extreme conditions (such as hypoxia or temperature) and multiple effects of the combination of abiotic parameters (such as in the hydrothermal vents) indicate complex ecological and biological interactions. Recent discoveries of meiofauna living in hostile environments (hypersaline/anoxic conditions) have opened new frontiers in ecology and biology and their specific adaptations make them particularly suitable as biological indicators.

Foraminiferans and nematodes are very abundant in almost all extreme marine environments and they dominate deep-sea ecosystems generally. However, there are some exceptions, such as in cold seeps and environments with drastic changes in salinity in which kinorhynchs are particularly abundant and well adapted, or polar ecosystems

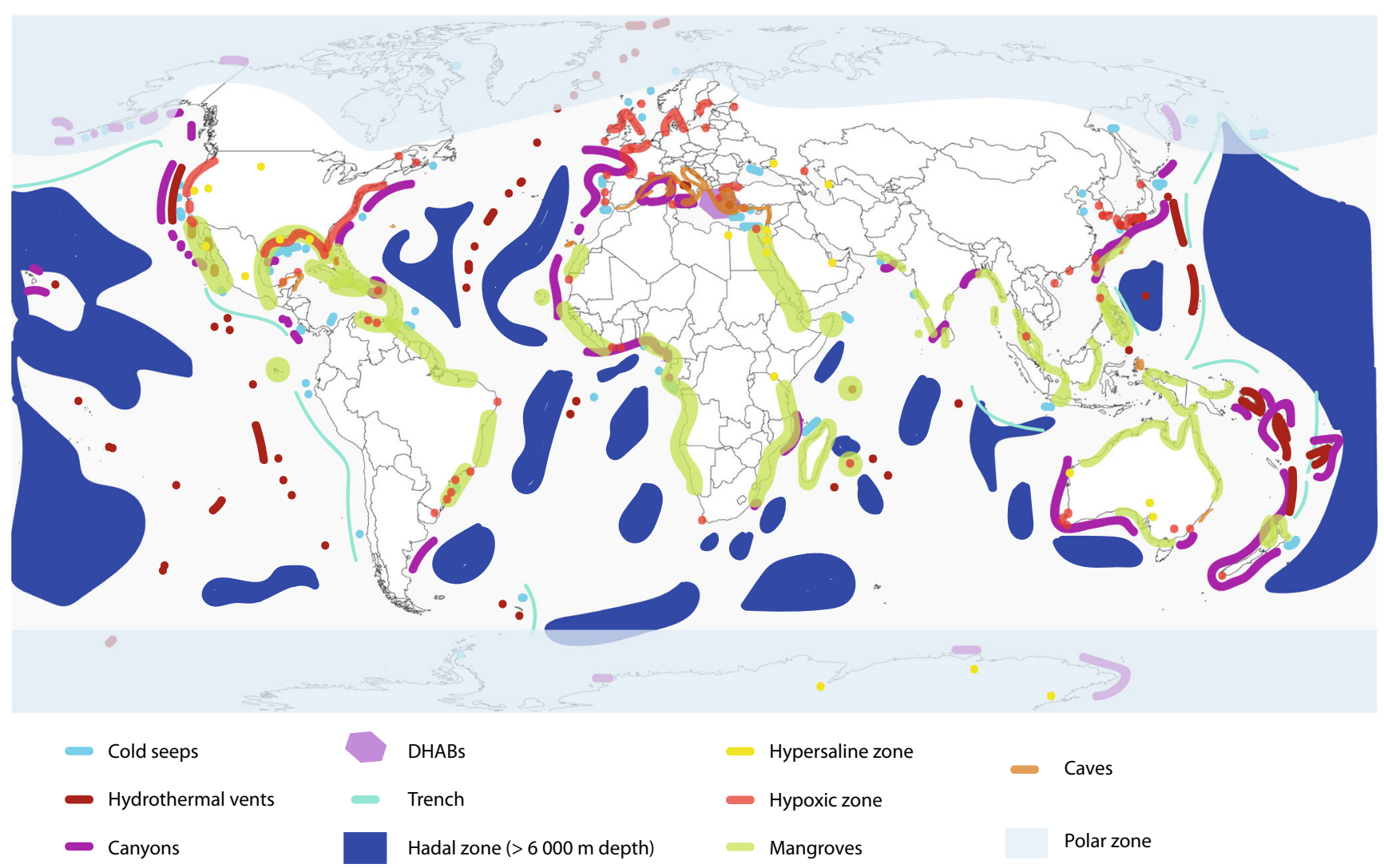

Fig. 4 Illustrative chart of the distribution of extreme marine environments 
where rotifers are particularly well represented. It is worth highlighting that loriciferans seem to be the only organism able to survive to the multiple extreme conditions of DHABs (both anoxic and hypersaline conditions).

The behavioural and physiological adaptations of meiofaunal taxa living in extreme environments can provide vital insights on how organisms may adapt to polluted environments or to changing environmental conditions. Species that thrive in extreme conditions can also be used as indicators of anthropogenic impacts (Zeppilli et al. 2015b). For example, the nematode Halomonhystera shows ovoviviparous reproduction in sulphide-rich seep sediments, an adaptation which likely enhances its resistance to anthropogenic pollutants (Vranken et al. 1991; Van Gaever et al. 2006). In extreme environments, chemosynthetic microorganisms convert energy in the form of reduced sulphur compounds or methane via oxygenation. Some extreme meiofauna organisms graze selectively and exclusively on the free-living microorganisms or are associated with microorganisms, as in the case of Parastomonema, a mouthless group of nematodes with chemosynthetic endosymbionts, or Stilbonematinae, nematodes covered by ectosymbiotic bacteria.

Some extreme systems, such as the deep sea and certain caves, share ecological features, including stable hydrodynamic conditions, permanent darkness, and extreme oligotrophy, resulting in lack of photosynthetic production and low food supply (Riedl 1966). Likewise, hydrothermal vents, some gas seeps and caves are characterised by low oxygen levels and presence of reduced sulphide compounds. Currently, we know several megafauna and macrofauna bathyal species living also in the darkest parts of caves (Harmelin 1997; Bakran-Petricioli et al. 2007; Janssen et al. 2013), which suggests a connection between deep waters and the euphotic zone through dispersal mechanisms such as upwelling processes (Janssen et al. 2013). Powerful upwelling of deep-water masses from bathyal canyons may bring propagules from deep waters, reaching shallower waters and giving rise to stable communities when they arrive to favourable habitats. However, the similar fauna of some extreme environments may also be a result of an adaptive convergence process resulting from similar environmental conditions. Meiofaunal animals, without larval dispersion, may play a key role in investigating this challenging situation, as well as to study ecological and evolutionary patterns to survive in such harsh life conditions. The discovery of new meiofaunal taxa in extreme environments can provide insights into the phylogeny and evolution of certain groups.

Extremophiles have impressive economic potential, for example, in agriculture, chemical synthesis, laundry detergents and pharmaceutical products (Rothschild and Mancinelli 2001). The peculiar microbial and physico- chemical conditions of marine extreme environments make extremophile metazoans model organisms to investigate antimicrobial peptides (AMPs) important components of the natural defences against invading pathogens with microbial cytotoxic activity exploitable as potential natural antibiotics (see Box I).

Box I. The use of marine extremophile metazoans for the discovery of a novel generation of drugs

AMPs are key components of the innate immune system that are produced by all living organisms. These small antibiotic molecules rapidly eradicate or incapacitate pathogenic agents such as viruses, bacteria or fungi, attempting not only to invade but also to proliferate within multi-cellular eukaryotes (Zasloff 2002; Bulet et al. 2004; Maróti et al. 2011). In the last decade, AMPs have also been shown to control and confine the symbiotic microflora in specific anatomical compartments (e.g. gut, bacteriomes, skin), thus contributing to the symbiostasis of both invertebrates and vertebrates (Salzman et al. 2009; Gallo and Nakatsuji 2011; Login et al. 2011; Franzenburg et al. 2013; Tasiemski et al. 2015). A substantial body of data demonstrates that AMPs not only act internally but can also be secreted into the environment surrounding an organism where they participate in external immunity, referred to as "any heritable trait acting outside of an organism improving protection from pathogens or manipulating the composition of the microbial community in favor of an organism" (Otti et al. 2014). In the case of extreme, frequently disturbed and stressful environments, the external immunity of an organism will depend on its ability to control the functioning of its externally secreted immune products under very variable conditions. In a sense, the coevolution of both the host immune system and the microbial communities in extreme environments adds another constraint to the usual Red Queen model, namely coevolution of two partners submitted to harsh selection for local adaptation to fluctuating environmental conditions, and this scenario has yet to be fully understood. Extremophile organisms lacking structural barriers of the body (e.g. cuticular exoskeleton or shell) to physically protect their underlying tissues from direct biotic/abiotic interactions are particularly suited to studying the adaptation of external immunity to changing and harsh environmental conditions. Rather than physical protection, annelids have developed a strong external immunity based on the production of mucus and AMPs by the epidermic cells that respectively trap and kill/select pathogenic/symbiotic bacteria (Salzet et al. 2006; Tasiemski and Salzet 2010; Conlon 2011; Gallo and Nakatsuji 2011). For instance, polychaetes produce original AMPs, some of which are restricted to just one worm family (e.g. preproalvinellacin) or even a single species (e.g. preprohedistin). This suggests that a high AMP selection at the inter-specific level has probably occurred during the evolutionary history of these organisms and in relation to their ecology (Schikorski et al. 2008; Tasiemski et al. 2014). At the intra-specific level, highly fluctuating physico-chemical conditions did not promote a differentiating selection of AMP genes per se in contrast to the situation generally observed in other metazoans. On the contrary, a strong purifying selection is evident, despite the duplication-driven diversification of its chaperone containing precursor. Duplication of genes has often been viewed as a molecular mechanism by which animals or plants adapt to changing environmental conditions with little cost (James et al. 2008). Recent data demonstrate that exhibiting a vital and highly conserved ecto-symbiosis in the face of thermal fluctuations has led to a peculiar selective trend promoting the adaptive diversification of the molecular chaperone of an AMP, but not of the AMP itself. This finding significantly differs from previous results, as no 
polymorphism (following the 'matching allele' model of Red Queen theory) nor duplication and ensuing divergence (following the 'gene-for-gene' model) was observed for the AMP produced by Alvinellidae (Papot et al. 2017). Because of their abundance and the strong interaction with microorganisms, the study of the immune system of meiofauna species has yet to be investigated to better understand how their immune genes evolve to allow the establishment of detoxifying symbiosis vital to thrive in extreme and changing habitats.

In summary, meiofauna from extreme environments can be particularly valuable in ecological, biological, physiological and evolutionary studies, with a potential for economic exploitation. Nevertheless, meiofaunal taxonomic identification remains a challenge. Some extreme meiofauna groups are abundant but often neglected for lack of experts (e.g. flatworms). The development of molecular approaches such as high-throughput next-generation sequencing (Fonseca et al. 2010) and proteomic fingerprinting (Laakmann et al. 2013) is expected to help facilitate the characterisation of meiofaunal communities. Physiological studies on extreme environments are almost absent. In the case of loricifers from DHABs, a comparative study focused on the differences at the ultrastructural, physiological and molecular level that characterise aerobic and anaerobic loriciferans may help to understand the evolutionary history of this phylum.

Extreme ecosystems are particularly sensitive and vulnerable to human disturbance and exploitation. Faced by the rapid increase of mineral mining and gas/hydrocarbon exploration and exploitation projects, several extreme ecosystems are threatened (hydrothermal vents or cold seeps). Given the current outlook on meiofauna from extreme marine environments, several fields of knowledge such as assemblage, ecology, biology and physiology need further and deeper investigations, giving an integrative view of these scopes.

\footnotetext{
Acknowledgements The authors thank the western France laboratory cluster (Laboratoire d'Excellence) LabexMER (ANR-10-LABX-19), the French Research Institute for the Exploitation of the Sea (IFREMER), the Institut Carnot, the Total Foundation, the Océanopolis aquarium, the Zone Atelier Brest Iroise, the Finistère Departmental Council, the University of Western Brittany, the Brest Métropole Océane, the Brittany Regional Council, the European Institute for Marine Studies, the bank CASDEN Banque Populaire: Banque de l'Education, Recherche et Culture, the Banque Populaire de l'Ouest, the platform PERISCOPE and Grenier Photo for financing the MeioScool2013 project: Meiofaunal International Workshop, held in Brest (26-29 November 2013) and the MeioScool2016 project: Meiofaunal Summer School, held in Brest (27 June-01 July 2016). A group of M1 students from IUEM (Institut Universitaire Européen de la Mer, Brest) participated in the workshop MeioScool2013, reviewing all the studies available on extreme meiofauna under the supervision of Zeppilli D. and Fernandes D. From their work, the invited speakers of MeioScool2013 and MeioScool2016 and other participants of both workshops participated in the manuscript. DZ was supported by the project "Deep-sea hYdrothermal Vent nematodes as potential source of new Antibiotics" (DYVA) funded by the Total Fondation and IFREMER and by the project "Prokaryote-nematode
}

Interaction in marine extreme envirONments: a uniquE source for ExploRation of innovative biomedical applications" (PIONEER) funded by the Total Fondation and IFREMER. VNI was supported by a grant from the Russian Scientific Foundation (\#14-50-00029). DF and VNI work under a CNR-RFBR Italian-Russian bilateral agreement grant (RFBR grant 15-5478061). We thank A. Cattaneo (Ifremer) for the helpful comments.

Open Access This article is distributed under the terms of the Creative Commons Attribution 4.0 International License (http:// creativecommons.org/licenses/by/4.0/), which permits unrestricted use, distribution, and reproduction in any medium, provided you give appropriate credit to the original author(s) and the source, provide a link to the Creative Commons license, and indicate if changes were made.

\section{References}

Aarset AV (1991) The ecophysiology of under-ice fauna. Polar Res 10; 309-324

Adrianov AV, Maiorova AS (2015) Pycnophyes abyssorum sp. n. (Kinorhyncha: Homalorhagida), the deepest kinorhynch species described so far. Deep Sea Res II Top Stud Oceanogr 111:49-59

Adrianov AV, Maiorova AS (2016) Condyloderes kurilensis sp. nov. (Kinorhyncha: Cyclorhagida) - a new deep water species from the abyssal plain near the Kuril-Kamchatka trench. Russ J Mar Biol 42: 11-19

Akimoto K, Hattori M, Uematsu K, Kato C (2001) The deepest living foraminifera, challenger deep, Mariana Trench. Mar Micropaleontol 42:95-97

Alongi DM (1987) The influence of mangrove-derived tannins on intertidal meiobenthos in tropical estuaries. Oecologia 71:537-540

Álvarez Castillo L, Hermoso Salazar M, Estradas-Romero A, ProlLedesma RM, Pardos Martínez F (2015) First records of Kinorhyncha from the Gulf of California: horizontal and vertical distribution of four genera in shallow basins with $\mathrm{CO}_{2}$ venting activity. Cahiers de Biologie Marine 56(3):271-281

Amaro T, Huvenne VAI, Allcock AL, Aslam T, Davies JS, Danovaro R, De Stigter HC, Duineveld GCA, Gambi C, Gooday AJ, Gunton LM, Hall R, Howell KL, Ingels J, Kiriakoulakis K, Kershaw CE, Lavaleye MSS, Robert K, Stewart H, Van Rooij D, White M, Wilson AM (2016) The Whittard Canyon - a case study of submarine canyon processes. Prog Oceanogr 146:38-57

Annapurna C, Rao MS, Bhanu ChV (2015) Distribution of meiobenthos off Kakinada Bay, Gaderu and Coringa estuarine complex. J Mar Biol Assoc India 57:17-26

Anschutz P, Jorissen FJ, Chaillou G, Abu-Zied R, Fontanier C (2002) Recent turbidite deposition in the eastern Atlantic: early diagenesis and biotic recovery. J Mar Res 60:835-854

Ape F, Arigo C, Gristina M, Genovese L, Di Franco A, Di Lorenzo M, Baiata P, Aglieri G, Milisenda G, Mirto S (2015) Meiofaunal diversity and nematode assemblages in two submarine caves of a Mediterranean marine protected area. Mediterr Mar Sci 17:202-215

Austen MC, Warwick RM, Ryan KP (1993) Astomonema southwardorum sp. nov., a gutless nematode dominant in a methane seep area in the North Sea. J Mar Biol Assoc UK 73:627-634

Baguley JG, Montagna PA, Hyde LJ, Kalke RD, Rowe GT (2006) Metazoan meiofauna abundance in relation to environmental variables in the northern Gulf of Mexico deep sea. Deep Sea Res I Oceanogr Res Pap 53:1344-1362

Bakran-Petricioli T, Vacelet J, Zibrowius H, Petricioli D, Chevaldonné P, Rada T (2007) New data on the distribution of the 'deep-sea' 
sponges Asbestopluma hypogea and Oopsacas minuta in the Mediterranean Sea. Mar Ecol 28:10-23

Bassler-Veit B, Barut IF, Meric E, Avsar N, Nazik A, Kapan-Yeșilyurt S, Yildiz A (2013) Distribution of microflora, meiofauna, and macrofauna assemblages in the hypersaline environment of northeastern Aegean Sea coasts. J Coast Res 29(4):883-898

Bellard C, Bertelsmeier C, Leadley P, Thuiller W, Courchamp F (2012) Impacts of climate change on the future of biodiversity. Ecol Lett 15(4):365-377

Belyaev GM (1972) Hadal bottom fauna of the world ocean. In: Zenkevich LA (ed) Israel program for scientific translations catalog. Israel Program for Scientific Translations, Jerusalem 199 pp

Belyaev GM (1989) Deep-sea ocean trenches and their fauna. Nauka, Moscow

Bernhard JM (2003) Potential symbionts in bathyal foraminifera. Science 299:861

Bernhard JM, Bowser SS (1999) Benthic foraminifera of dysoxic sediments: chloroplast sequestration and functional morphology. Earth Sci Rev 46:149-165

Bernhard JM, Bowser SS (2008) Peroxisome proliferation in foraminifera inhabiting the chemocline: an adaptation to reactive oxygen species exposure? J Eukaryot Microbiol 55:135-144

Bernhard JM, Sen Gupta BK (1999) Foraminifera of oxygen-depleted environments. In: Sen Gupta BK (ed) Modern foraminifera. Kluwer Academic Publishers, Dordrecht, pp 201-216

Bernhard JM, Buck KR, Barry JP (2001) Monterey Bay cold-seep biota: assemblages, abundance, and ultrastructure of living foraminifera. Deep Sea Res I Oceanogr Res Pap 48:2233-2249

Bernhard JM, Martin JB, Rathburn AE (2010) Combined carbonate carbon isotopic and cellular ultrastructural studies of individual benthic foraminifera: 2. Toward an understanding of apparent disequilibrium in hydrocarbon seeps. Paleoceanography 25:PA4206. https:// doi.org/10.1029/2010PA001930

Bernhard JM, Morrison CR, Pape E, Beaudoin DJ, Todaro MA, Pachiadaki MG, Kormas KAr, Edgcomb VP (2015) Metazoans of redoxcline sediments in Mediterranean deep-sea hypersaline anoxic basins. BMC Biol 13:105

Bianchelli S, Gambi C, Pusceddu A, Danovaro R (2008) Trophic conditions and meiofaunal assemblages in the Bari Canyon and the adjacent open slope (Adriatic Sea). Chem Ecol 24:101-109

Bianchelli S, Gambi C, Zeppilli D, Danovaro R (2010) Metazoan meiofauna in deep-sea canyons and adjacent open slopes: a largescale comparison with focus on the rare taxa. Deep Sea Res I Oceanogr Res Pap 57:420-433

Bienhold C, Pop Ristova P, Wenzhöfer F, Dittmar T, Boetius A (2013) How deep-sea wood falls sustain chemosynthetic life. PLoS One 8(1):e53590. https://doi.org/10.1371/journal.pone.0053590

Blome D, Riemann F (1999) Antarctic sea ice nematodes, with description of Geomonhystera glaciei sp. nov. (Monhysteridae). Mitt Hamb Zool Mus Inst 96:15-20

Blumberg S, Lamy F, Arz HW, Echtler HP, Wiedicke M, Haug GH, Oncken O (2008) Turbiditic trench deposits at the South-Chilean active margin: a Pleistocene-Holocene record of climate and tectonics. Earth Planet Sci Lett 268:526-539

Boesgaard TM, Kristensen RM (2001) Tardigrades from Australian marine caves. With a redescription of Actinarctus neretinus (Arthrotardigrada). Zool Anz 240:253-264

Bolliet T, Jorissen FJ, Schmidt S, Howa H (2014) Benthic foraminifera from Capbreton Canyon revisited; faunal evolution after repetitive sediment disturbance. Deep Sea Res II Top Stud Oceanogr 104:319 334

Bouillon S, Connolly RM, Lee SY (2008) Organic matter exchange and cycling in mangrove ecosystems: recent insights from stable isotope studies. J Sea Res 59(1-2):44-58

Bradshaw JS (1961) Laboratory experiments on the ecology of foraminifera. Contrib Cushman Found Foram Res 12:87-106
Brierley AS, Thomas DN (2002) Ecology of Southern Ocean pack ice. Adv Mar Biol 43:171-276

Bright M (2006) Hydrothermal vent meiofauna. Denisia 18:27-28

Bright M, Plum C, Riavitz LA, Nikolov N, Martinez Arbizu P, Cordes EE, Gollner S (2010) Epizooic metazoan meiobenthos associated with tubeworm and mussel aggregations from cold seeps of the northern Gulf of Mexico. Deep Sea Res II Top Stud Oceanogr 57: 1982-1989

Brown R (1985) Developmental and taxonomic studies of Sydney Harbour Kinorhyncha. Dissertation, Macquarie University, Australia

Bulet P, Stöcklin R, Menin L (2004) Anti-microbial peptides: from invertebrates to vertebrates. Immunol Rev 198:169-184

CAREX (2011) CAREX roadmap for research on life in extreme environment. CAREX Project Office, Strasbourg, $48 \mathrm{pp}$

Carman KR, Thistle D, Fleeger JW, Barry JP (2004) Influence of introduced $\mathrm{CO} 2$ on deep-sea metazoan meiofauna. J Oceanogr 60:767772

Carrasco NK, Perissinotto R (2012) Development of a halotolerant community in the St. Lucia Estuary (South Africa) during a hypersaline phase. PLoS One 7:e29927

Catalan J, Camarero L, Felip M, Pla S, Ventura M, Buchaca T, Bartumeus F, Mendoza GD, Miró A, Casamayor EO, Medina-Sánchez JM (2006) High mountain lakes: extreme habitats and witnesses of environmental changes. Limnetica 25(1-2):551-584

Cavalieri DJ, Parkinson CL, Vinnikov KY (2003) 30-Year satellite record reveals contrasting Arctic and Antarctic decadal sea ice variability. Geophys Res Lett 30(18). https://doi.org/10.1029/2003GL018031

Cavicchioli R, Amils R, Wagner D, McGenity T (2011) Life and applications of extremophiles. Environ Microbiol 13:1903-1907

Charmasson S, Sarradin P-M, Le Faouder A, Agarande M, Loyen J, Desbruyères D (2009) High levels of natural radioactivity in biota from deep-sea hydrothermal vents: a preliminary communication. J Environ Radioactiv 100:522-526

Clarke A, Peck LS (1991) The physiology of polar marine zooplankton. Polar Res 10:355-370

Colangelo MA, Bertasi R, Dall'Olio P, Ceccherelli VH (2001) Meiofaunal biodiversity on hydrothermal seepage off Panarea (Aeolian Islands, Tyrrhenian Sea). In: Faranda FM, Guglielmo L, Spezie G (eds) Mediterranean ecosystems: structures and processes. Springer-Verlag, Berlin Heidelberg, pp 353-359

Comiso JC, Nishio F (2008) Trends in the sea ice cover using enhanced and compatible AMSR-E, SSM/I, and SMMR data. J Geophys Res 113:C02S07

Conlon JM (2011) The contribution of skin antimicrobial peptides to the system of innate immunity in anurans. Cell Tissue Res 343:201-212

Conover RJ, Huntley M (1991) Copepods in ice-covered seas-distribution, adaptations to seasonally limited food, metabolism, growth patterns and life cycle strategies in polar seas. J Mar Syst 2:1-41

Convey P, McInnes SJ (2005) Exceptional tardigrade-dominated ecosystems in Ellsworth Land, Antarctica. Ecology 86(2):519-527

Copley JTP, Flint HC, Ferrero TJ, Van Dover CL (2007) Diversity of meiofauna and free-living nematodes in hydrothermal vent mussel beds on the northern and southern East Pacific Rise. J Mar Biol Assoc UK 87:1141-1152

Cornelius N, Gooday AJ (2004) 'Live' (stained) deep-sea benthic foraminiferans in the western Weddell Sea: trends in abundance, diversity and taxonomic composition along a depth transect. Deep Sea Res II Top Stud Oceanogr 51:1571-1602

Coull BC (1985) Long-term variability of estuarine meiobenthos: an 11 year study. Mar Ecol Prog Ser 24:205-218

Coull BC (1999) Role of meiofauna in estuarine soft-bottom habitats. Aust Ecol 24:327-343

Cuvelier D, Beesau J, Ivanenko VN, Zeppilli D, Sarradin PM, Sarrazin J (2014) First insights into macro- and meiofaunal colonisation 
patterns on paired wood/slate substrata at Atlantic deep-sea hydrothermal vents. Deep Sea Res I Oceanogr Res Pap 87:70-81

Dal Zotto M, Todaro MA (2016) Kinorhyncha from Italy, a revision of the current checklist and an account of the recent investigations. Zool Anz 265:90-107

Dando PR, Austen MC, Burke RA Jr, Kendall MA, Kennicutt MC, Judd AG, Moore DC, O'Hara SCM, Schmalijohann R, Southward AJ (1991) Ecology of a North Sea pockmark with an active methane seep. Mar Ecol Prog Ser 70:49-63

Dando PR, Hughes JA, Thiermann F (1995) Preliminary observations on biological communities at shallow hydrothermal vents in the Aegean Sea. Geol Soc Spec Publ 87:303-317

Danielopol DL (1990) The origin of the anchialine cave fauna-the "deep sea" versus the "shallow water" hypothesis tested against the empirical evidence of the Thaumatocyprididae (Ostracoda). Bijdr Dierkd 60(3/4):137-143

Danovaro R (2010) Methods for the study of deep-sea sediments, their functioning and biodiversity. CRC Press, Boca Raton

Danovaro R, Dinet A, Duineveld G, Tselepides A (1999) Benthic response to particulate fluxes in different trophic environments: a comparison between the Gulf of Lions-Catalan Sea (westernMediterranean) and the Cretan Sea (eastern-Mediterranean). Prog Oceanogr 44:287-312

Danovaro R, Gambi C, Della Croce N (2002) Meiofauna hotspot in the Atacama Trench, eastern South Pacific Ocean. Deep Sea Res I Oceanogr Res Pap 49:843-857

Danovaro R, Bianchelli S, Gambi C, Mea M, Zeppilli D (2009) Alpha-, beta-, gamma-, delta- and epsilon-diversity of deep-sea nematodes in canyons and open slopes of Northeast Atlantic and Mediterranean margins. Mar Ecol Prog Ser 396:197-210

Danovaro R, Company JB, Corinaldesi C, D’Onghia G, Galil B, Gambi C, Gooday AJ, Lampadariou N, Luna GM, Morigi C, Olu K, Polymenakou P (2010a) Deep-sea biodiversity in the Mediterranean Sea: the known, the unknown, and the unknowable. PLoS One 5:25

Danovaro R, Dell'Anno A, Pusceddu A, Gambi C, Heiner I, Kristensen RM (2010b) The first metazoa living in permanently anoxic conditions. BMC Biol 8:1-30

Danovaro R, Gambi C, Dell'Anno A, Corinaldesi C, Pusceddu A, Neves RC, Kristensen RM (2016) The challenge of proving the existence of metazoan life in permanently anoxic deep-sea sediments. BMC Biol 14:43-50

Dawson MN (2016) Island and island-like marine environments. Glob Ecol Biogeogr 25(7):831-846

de Bovée F, Guidi LD, Soyer J (1990) Quantitative distribution of deepsea meiobenthos in the northwestern Mediterranean (Gulf of Lions). Continental Shelf Res 10:1123-1145

De Broyer C, Koubbi P, Griffiths HJ, Raymond B, d'Udekem d'Acoz C, Van de Putte AP, Danis B, David B, Grant S, Gutt J, Held C, Hosie G, Huettmann F, Post A, Ropert-Coudert Y (eds) (2014) Biogeographic atlas of the Southern Ocean. Scientific Committee on Antarctic Research, Cambridge, XII + 498 pp

De Leo FC, Smith CR, Rowden AA, Bowden DA, Clark MR (2010) Submarine canyons: hotspots of benthic biomass and productivity in the deep sea. Proc R Soc Lond B Biol Sci 277:2783-2792

de Stigter HC, Boer W, de Jesús Mendes PA, Jesús CC, Thomsen L, van den Bergh GD, van Weering TCE (2007) Recent sediment transport and deposition in the Nazaré Canyon, Portuguese continental margin. Mar Geol 246:144-164

De Troch M, Roelofs M, Riedel B, Grego M (2013) Structural and functional responses of harpacticoid copepods to anoxia in the Northern Adriatic: an experimental approach. Biogeosciences 10:4259-4272

Debenham NJ, Lambshead PJD, Ferrero TJ, Smith CR (2004) The impact of whale falls on nematode abundance in the deep sea. Deep Sea Res I Oceanogr Res Pap 51:701-706
Degen R, Riavitz L, Gollner S, Vanreusel A, Plum C, Bright M (2012) Community study of tubeworm-associated epizooic meiobenthos from deep-sea cold seeps and hot vents. Mar Ecol Prog Ser 468: $135-148$

Della Patrona L, Marchand C, Hubas C, Molnar N, Deborde J, Meziane T (2016) Meiofauna distribution in a mangrove forest exposed to shrimp farm effluents (New Caledonia). Mar Environ Res 119: $100-113$

De Mesel I, Lee HJ, Vanhove S, Vinex M, Vanreusel A (2006) Species diversity and distribution within the deep-sea nematode genus Acantholaimus on the continental shelf and slope in Antarctica. Polar Biol 29:860-871

Demopoulos AWJ, Fry B, Smith CR (2007) Food web structure in exotic and native mangroves: a Hawaii-Puerto Rico comparison. Oecologia 153:675-686

Diaz RJ (2001) Overview of hypoxia around the world. J Env Qual 30: 275-281

Diaz RJ, Rosenberg R (1995) Marine benthic hypoxia: a review of its ecological effects and the behavioural responses of benthic macrofauna. Oceanogr Mar Biol Ann Rev 33:245-303

Dinet A, Grassle F, Tunnicliffe V (1988) Premières observations sur la meiofaune des sites hydrothermaux de la dorsale Est-Pacifique (Guaymas, 21 degree N) et de l'Explorer Ridge. Oceanol Acta 85: $7-14$

Duros P, Fontanier C, Metzger E, Pusceddu A, Cesbron F, De Stigter HC, Bianchelli S, Danovaro R, Jorissen FJ (2011) Live (stained) benthic foraminifera in the Whittard Canyon, Celtic margin (NE Atlantic). Deep Sea Res I Oceanogr Res Pap 58:128-146

Duros P, Fontanier C, de Stigter HC, Cesbron F, Metzger E, Jorissen FJ (2012) Live and dead benthic foraminiferal faunas from Whittard Canyon (NE Atlantic): focus on taphonomic processes and paleoenvironmental applications. Mar Micropaleontol 94-95:25-44

Duros P, Silva Jacinto R, Dennielou B, Schmidt S, Martinez Lamas R, Gautier E, Roubi A, Gayet N (2017) Benthic foraminiferal response to sedimentary disturbance in the Capbreton canyon (Bay of Biscay, NE Atlantic). Deep Sea Res I Oceanogr Res Pap 120:61-75

Dye AH (1983) Composition and seasonal fluctuations of meiofauna in a southern African mangrove estuary. Mar Biol 73:165-170

Edgcomb V, Orsi W, Leslin C, Epstein SS, Bunge J, Jeon S, Yakimov MM, Behnke A, Stoeck T (2009) Protistan community patterns within the brine and halocline of deep hypersaline anoxic basins in the eastern Mediterranean Sea. Extremophiles 13:151-167

Eicken H (1992) The role of sea ice in structuring Antarctic ecosystems. Polar Biol 12:3-13

Fabiano M, Danovaro R (1999) Meiofauna distribution and mesoscale variability in two sites of the Ross Sea (Antarctica) with contrasting food supply. Polar Biol 22:115-123

Fichez R (1990) Decrease in allochthonous organic inputs in dark submarine caves, connection with lowering in benthic community richness. Hydrobiol 207:61-69

Flint HC, Copley JTP, Ferrero TJ, Van Dover CL (2006) Patterns of nematode diversity at hydrothermal vents on the East Pacific Rise. Cah Biol Mar 47:365-370

Fogg GE (1998) The biology of polar habitats. Oxford University Press, New York

Fonseca VG, Carvalho GR, Sung W, Johnson HF, Power DM, Neill SP, Packer M, Blaxter ML, Lambshead PJ, Thomas WK, Creer S (2010) Second-generation environmental sequencing unmasks marine metazoan biodiversity. Nature Comm 1:98

Fonseca G, Hutchings P, Vieira DC, Gallucci F (2011) Meiobenthic community underneath the carcass of a stingray: a snapshot after natural death. Aquat Biol 13:27-33

Fontaneto D, Iakovenko N, De Smet WH (2015) Diversity gradients of rotifer species richness in Antarctica. Hydrobiol 761(1):235-248

Fontanier C, Duros P, Toyofuku T, Oguri K, Koho KA, Buscail R, Grémare A, Radakovitch O, Deflandre B, De Nooijer LJ, Bichon 
S (2014a) Living (stained) deep-sea foraminifera off Hachinohe (NE Japan, Western Pacific): environmental interplay in oxygen-depleted ecosystems. J Foramin Res 44:281-299

Fontanier C, Koho KA, Goñi-Urriza MS, Deflandre B, Galaup S, Ivanovsky A, Gayet N, Dennielou B, Grémare A, Bichon S, Gassie C, Anschutz P, Duran R, Reichart GJ (2014b) Benthic foraminifera from the deep-water Niger delta (Gulf of Guinea): assessing present-day and past activity of hydrate pockmarks. Deep Sea Res I Oceanogr Res Pap 94:87-106

Foucher JP, Westbrook GK, Boetius A, Ceramicola SI, Dupré S, Mascle J, Mienert J, Pfannkuche O, Pierre C, Praeg D (2009) Structure and drivers of cold seep ecosystems. Oceanography 22:92-109

Franzenburg S, Walter J, Künzel S, Wang J, Baines JF, Bosch TC, Fraune S (2013) Distinct antimicrobial peptide expression determines host species-specific bacterial associations. Proc Natl Acad Sci U S A 110:E3730-E3738

Friedrich C (1997) Ecological investigations on the fauna of the Arctic sea-ice. Rep Polar Res 246:1-211

Fujii T, Kilgallen NM, Rowden AA, Jamieson AJ (2013) Deep-sea amphipod community structure across abyssal to hadal depths in the Peru-Chile and Kermadec trenches. Mar Ecol Prog Ser 492:125138

Fujimoto S (2015) Quisarctus yasumurai gen. et sp. nov. (Arthrotardigrada: Halechiniscidae) from a submarine cave, off Iejima, Ryukyu Islands, Japan. Zootaxa 3948:145-150

Fujioka K, Okino K, Kanamatsu T, Ohara Y (2002) Morphology and origin of the Challenger Deep in the Southern Mariana Trench. Geophys Res Let 29:10-1-10-4

Fujiwara Y, Kawato M, Yamamoto T, Yamanaka T, Sato-Okoshi W, Noda C, Tsuchida S, Komai T, Cubelio SS, Sasaki T, Jacobsen K, Kubokawa K, Fujikura K, Maruyama T, Furushima Y, Okoshi K, Miyake H, Miyazaki M, Nogi Y, Yatabe A, Okutani T (2007) Threeyear investigations into sperm whale-fall ecosystems in Japan. Mar Ecol 28:219-232

Funch P, Segers H, Dumont HJ (1996) Rotifera in tap water in gent, Belgium. Biol Jaarb Dodonaea 63:53-57

Gage JD, Tyler PA (1991) Deep-sea biology: a natural history of organisms at the deep-sea floor. Cambridge University Press, Cambridge

Gallo RL, Nakatsuji T (2011) Microbial symbiosis with the innate immune defense system of the skin. J Invest Dermatol 131:1974-1980

Gallo ND, Cameron J, Hardy K, Fryer P, Bartlett DH, Levin LA (2015) Submersible- and lander-observed community patterns in the Mariana and New Britain trenches: influence of productivity and depth on epibenthic and scavenging communities. Deep Sea Res I Oceanogr Res Pap 99:119-133

Gallo D'Addabbo M, de Zio Grimaldi S, Sandulli R (2001) Heterotardigrada of two submarine caves in S. Domino Island (Tremiti Islands) in the Mediterranean Sea with the description of two new species of Stygarctidae. Zool Anz 240:361-369

Gambi C, Danovaro R (2016) Biodiversity and life strategies of deep-sea meiofauna and nematode assemblages in the Whittard Canyon (Celtic margin, NE Atlantic Ocean). Deep Sea Res I Oceanogr Res Pap 108:13-22

Gambi C, Vanreusel A, Danovaro R (2003) Biodiversity of nematode assemblages from deep-sea sediments of the Atacama Slope and Trench (South Pacific Ocean). Deep Sea Res I Oceanogr Res Pap 50:103-117

Garcia R, Koho KA, De Stigter HC, Epping E, Koning E, Thomsen L (2007) Distribution of meiobenthos in the Nazare canyon and adjacent slope (western Iberian Margin) in relation to sedimentary composition. Mar Ecol Prog Ser 340:207-220

Gee JM, Somerfield PJ (1997) Do mangrove diversity and leaf litter decay promote meiofaunal diversity? J Exp Mar Biol Ecol 218: $13-33$

George KH (2014) Southern Ocean Harpacticoida (Crustacea: Copepoda). In: De Broyer C, Koubbi P, Griffiths HJ, Raymond B,
d'Udekem d'Acoz C, Van de Putte AP, Danis B, David B, Grant S, Gutt J, Held C, Hosie G, Huettmann F, Post A, Ropert-Coudert Y (eds) Biogeographic atlas of the Southern Ocean. Scientific Committee on Antarctic Research, Cambridge

Gerdes G, Spira J, Dimentman C (1985) The fauna of the Gavish Sabkha and the Solar Lake - a comparative study. In: Friedman GM, Krumbein WE (eds) Hypersaline ecosystems. Springer-Verlag, Berlin Heidelberg, pp 322-345

Gerlach SA, Riemann F (1973) The Bremerhaven checklist of aquatic nematodes. A catalogue of Nematoda Adenophorea excluding the Dorylaimida. Veröff Inst Meeresforsch Bremerhav 1:1-404

Giere O (1993) Meiobenthology: the microscopic fauna in aquatic sediments. Springer-Verlag, Berlin

Giere O (2009) Meiobenthology. The microscopic motile fauna of aquatic sediments, 2nd edn. Springer-Verlag, Berlin

Giere O, Windoffer R, Southward EC (1995) The bacterial endosymbiosis of the gutless nematode, Astomonema southwardorum: ultrastructural aspects. J Mar Biol Assoc UK 75:153-164

Glock N, Schönfeld J, Eisenhauer A, Hensen C, Mallon J, Sommer S (2012) The role of benthic foraminifera in the benthic nitrogen cycle of the Peruvian oxygen minimum zone. Biogeosci Discuss 9: 17775-17817

Glud RN, Wenzhöfer F, Middelboe M, Oguri K, Turnewitsch R, Canfield DE, Kitazato H (2013) High rates of microbial carbon turnover in sediments in the deepest oceanic trench on Earth. Nat Geosci 6:284 288

Gollner S, Zekely J, Van Dover C, Govenar B, Le Bris N, Nemeschkal H, Bright M (2006) Benthic copepod communities associated with tubeworm and mussel aggregations on the East Pacific Rise. Cah Biol Mar 47:397-402

Gollner S, Zekely J, Govenar B, Le Bris N, Nemeschkal HL, Fisher CR, Bright M (2007) Tubeworm-associated permanent meiobenthic communities from two chemically different hydrothermal vent sites on the East Pacific Rise. Mar Ecol Prog Ser 337:39-49

Gollner S, Ivanenko VN, Arbizu PM, Bright M (2010a) Advances in taxonomy, ecology, and biogeography of Dirivultidae (Copepoda) associated with chemosynthetic environments in the deep sea. PLoS One 5:e9801

Gollner S, Riemer B, Martínez Arbizu P, Le Bris N, Bright M (2010b) Diversity of meiofauna from the $9^{\circ} 50^{\prime} \mathrm{N}$ East Pacific Rise across a gradient of hydrothermal fluid emissions. PLoS One 5:e12321

Gollner S, Fontaneto D, Arbizu PM (2011) Molecular taxonomy confirms morphological classification of deep-sea hydrothermal vent copepods (Dirivultidae) and suggests broad physiological tolerance of species and frequent dispersal along ridges. Mar Biol 158(1):221231

Gollner S, Miljutina M, Bright M (2013) Nematode succession at deep-sea hydrothermal vents after a recent volcanic eruption with the description of two dominant species. Org Divers Evol 13:349-371

Gollner S, Govenar B, Fisher CR, Bright M (2015) Size matters at deepsea hydrothermal vents: different diversity and habitat fidelity patterns of meio- and macrofauna. Mar Ecol Prog Ser 520:57-66

Gollner S, Stuckas H, Kihara TC, Laurent S, Kodami S, Martinez Arbizu P (2016) Mitochondrial DNA analyses indicate high diversity, expansive population growth and high genetic connectivity of vent copepods (Dirivultidae) across different oceans. PLoS One 11(10): e 0163776

Gomes CAA, Dos Santos PJP, Alves TNC, Rosa-Filho JS, Souza-Santos LP (2002) Variação temporal da Meiofauna em Área de Manguezal em Itamaracá-Pernambuco. Atlântica, Rio Grande 24:89-96

Gomes NCM, Cleary DFR, Pinto FN, Egas C, Almeida A, Cunha A, Mendonça-Hagler LCS, Smalla K (2010) Taking root: enduring effect of rhizosphere bacterial colonization in mangroves. PLoS One 5(11):e14065 
Gooday AJ, Bernhard JM, Levin LA, Suhr SB (2000) Foraminifera in the Arabian Sea oxygen minimum zone and other oxygen-deficient settings: taxonomic composition, diversity, and relation to metazoan faunas. Deep Sea Res II Top Stud Oceanogr 47:25-54

Gooday AJ, Todo Y, Uematsu K, Kitazato H (2008a) New organic-walled Foraminifera (Protista) from the ocean's deepest point, the Challenger Deep (western Pacific Ocean). Zool J Linnean Soc 153:399-423

Gooday AJ, Kamenskaya OE, Kitazato H (2008b) The enigmatic, deepsea, organic-walled genera Chitinosiphon, Nodellum and Resigella (Protista): a taxonomic re-evaluation. Syst Biodivers 6:385-404

Gooday AJ, Levin LA, Aranda da Silva A, Bett BJ, Cowie GL, Dissard D, Gage JD, Hughes DJ, Jeffreys R, Lamont PA, Larkin KE, Muty SJ, Schumacher S, Whitcaft C, Woulds C (2009a) Faunal responses to oxygen gradients on the Pakistan margin: a comparison of foraminiferans, macrofauna and megafauna. Deep Sea Res II Top Stud Oceanogr 56:488-502

Gooday AJ, Jorissen F, Levin LA, Middelburg JJ, Naqvi SWA, Rabalais NN, Scranton M, Zhang J (2009b) Historical records of coastal eutrophication-induced hypoxia. Biogeosciences 6:1707-1745

Gooday AJ, Bett BJ, Escobar E, Ingole B, Levin LA, Neira C, Raman AV, Sellanes J (2010a) Habitat heterogeneity and its influence on benthic biodiversity in oxygen minimum zones. Mar Ecol 31:125-147

Gooday AJ, Uematsu K, Kitazato H, Toyofuku T, Young JR (2010b) Traces of dissolved particles, including coccoliths, in the tests of agglutinated foraminifera from the challenger deep (10,897 $\mathrm{m}$ water depth, western equatorial Pacific). Deep Sea Res I Oceanogr Res Pap 57:239-247

Gooday AJ, Rothe N, Bowser SS, Pawlowski J (2014) Benthic foraminifera. In: De Broyer C, Koubbi P, Griffiths HJ, Raymond B, d'Udekem d'Acoz C, Van de Putte AP, Danis B, David B, Grant S, Gutt J, Held C, Hosie G, Huettmann F, Post A, Ropert-Coudert Y (eds) Biogeographic atlas of the Southern Ocean. Scientific Committee on Antarctic Research, Cambridge

Gradinger R (1999) Integrated abundance and biomass of sympagic meiofauna in Arctic and Antarctic pack ice. Polar Biol 22:169-177

Gradinger RR (2001) Adaptation of Arctic and Antarctic ice metazoa to their habitat. Zool 104:339-345

Gradinger R (2002) Sea ice microorganisms. In: Bitten GE (ed) Encyclopedia of environmental microbiology. Wiley, New York, pp 2833-2844

Gradinger RR, Bluhm BA (2004) In-situ observations on the distribution and behavior of amphipods and Arctic cod (Boreogadus saida) under the sea ice of the high Arctic Canada Basin. Pol Biol 27:595-603

Gradinger RR, Meiners K, Plumley G, Zhang Q, Bluhm BA (2005) Abundance and composition of the sea-ice meiofauna in off-shore pack ice of the Beaufort Gyre in summer 2002 and 2003. Pol Biol 28:171-181

Gradinger R, Bluhm B, Iken K (2010) Arctic sea-ice ridges — safe havens for sea-ice fauna during periods of extreme ice melt? Deep Sea Res II Top Stud Oceanogr 57:86-95

Grego M, Stachowitsch M, Troch MD, Riedel B (2013) CellTracker Green labelling vs. rose bengal staining: CTG wins by points in distinguishing living from dead anoxia-impacted copepods and nematodes. Biogeosciences 10:4565-4575

Grémare A, Medernach L, deBovée F, Amouroux JM, Vétion G, Albert P (2002) Relationships between sedimentary organics and benthic meiofauna on the continental shelf and the upper slope of the Gulf of Lions (NW Mediterranean). Mar Ecol Prog Ser 234:85-94

Grimaldi de Zio S, D’Addabbo Gallo M, Morone de Lucia RM (1982a) Neostygarctus acanthophorus, n. gen. n. sp., nuovo Tardigrado marino del Mediterraneo. Cah Biol Mar 23:319-324

Grimaldi de Zio S, D'Addabbo Gallo M, Morone de Lucia RM, Vaccarella R, Grimaldi P (1982b) Quattro nuove specie di Halechiniscidae rinvenute in due grotte sottomarine dell'Italia meridionale (Tardigrada: Heterotardigrada). Cah Biol Mar 23:415426

Grzymski J, Schofield OM, Falkowski PG, Bernhard JM (2002) The function of plastids in the deep-sea benthic foraminifer, Nonionella stella. Limnol Ocean 47:1569-1580

Guilini K, Levin LA, Vanreusel A (2012) Cold seep and oxygen minimum zone associated sources of margin heterogeneity affect benthic assemblages, diversity and nutrition at the Cascadian margin (NE Pacific Ocean). Prog Oceanogr 96(1):77-92

Gwyther J, Fairweather PG (2005) Meiofaunal recruitment to mimic pneumatophores in a cool-temperate mangrove forest: spatial context and biofilm effects. J Exp Mar Biol Ecol 317:69-85

Hagen W, Auel H (2001) Seasonal adaptations and the role of lipids in oceanic zooplankton. Zoology 104:313-326

Harmelin J-G (1997) Diversity of bryozoans in a Mediterranean sublittoral cave with bathyal-like conditions: role of dispersal processes and local factors. Mar Ecol Prog Ser 153:139-152

Hart CW Jr, Manning RB, Iliffe TM (1985) The fauna of Atlantic marine caves: evidence of dispersal by sea floor spreading while maintaining ties to deep waters. Proc Biol Soc Wash 98:288-292

Hauquier F, Durán Suja L, Gutt J, Veit-Köhler G, Vanreusel A (2015) Different oceanographic regimes in the vicinity of the Antarctic peninsula reflected in benthic nematode communities. PLoS One 10(9):e0137527

Hazel JR, Williams EE (1990) The role of alterations in membrane lipid composition in enabling physiological adaptation of organisms to their physical environment. Prog Lipid Res 29:167-227

Heiner I, Boesgaard TM, Kristensen RM (2009) First time discovery of Loricifera from Australian waters and marine caves. Marine Biol Res 5:529-546

Heinz P, Sommer S, Pfannkuche O, Hemleben C (2005) Living benthic foraminifera in sediments influenced by gas hydrates at the Cascadia convergent margin, NE Pacific. Mar Ecol Prog Ser 304:77-89

Heip C, Vincx M, Vranken G (1985) The ecology of marine nematodes. Oceanogr Mar Biol Annu Rev 23:399-489

Helly JJ, Levin LA (2004) Global distribution of naturally occurring marine hypoxia on continental margins. Deep Sea Res I Oceanogr Res Pap 51:1159-1168

Heptner MV, Ivanenko VN (2002) Copepoda (Crustacea) of hydrothermal ecosystems of the World Ocean. Arthropoda Selecta 11(2):117134

Hess S, Jorissen FJ, Venet V, Abu-Zied R (2005) Benthic foraminiferal recovery after recent turbidite deposition in Cap Breton Canyon, Bay of Biscay. J Foram Res 35:114-129

Hess S, Jorissen FJ (2009) Distribution patterns of living benthic foraminifera from Cap Breton Canyon, Bay of Biscay: faunal response to sediment instability. Deep Sea Res I Oceanogr Res Pap 56:15551578

Higgins RP (1969) Indian Ocean Kinorhyncha: 1, Condyloderes and Sphenoderes, new Cyclorhagid genera. Smithsonian Contrib Zool 14:1-13

Higgins RP (1977) Two new species of Echinoderes (Kinorhyncha) from South Carolina. Trans Am Microsc Soc 96:340-354

Higgins RP, Thiel H (eds) (1988) Introduction to the study of meiofauna. Smithsonian Institution Press, Washington, $488 \mathrm{pp}$

Hicks GRF (1988) Systematics of the Donsiellinae Lang (Copepoda, Harpacticoida). J Nat Hist 22(3):639-684

Hodda M, Nicholas WL (1986) Temporal changes in littoral meiofauna from the Hunter River estuary. Aust J Mar Freshwater Res 37:729 741

Hoffmann AA, Parsons PA (1997) Extreme environmental change and evolution. Cambridge University Press, Cambridge

Hogarth PJ (1999) The biology of mangroves. Oxford University Press, Oxford

Hop H, Poltermann M, Lønne OJ, Falk-Petersen S, Korsnes R, Budgell WP (2000) Ice amphipod distribution relative to ice density and 
under-ice topography in the northern Barents Sea. Polar Biol 23: 357-367

Hop H, Mundy CJ, Gosselin M, Rossnagel AL, Barber DG (2011) Zooplankton boom and ice amphipod bust below melting sea ice in the Amundsen Gulf, Arctic Canada. Polar Biol 34:1947-1958

Hopper BE, Cefalu RC (1973) Free-living marine nematodes from Biscayne Bay, Florida V. Stilbonematinae: contributions to the taxonomy and morphology of the genus Eubostrichus greeff and related genera. Trans Am Microsc Soc 92:578-591

Horn TD (1978) The distribution of Echinoderes coulli (Kinorhyncha) along an interstitial salinity gradient. Trans Am Microsc Soc 97: 586-589

Horner R (1985) Sea ice biota. CRC Press, Boca Raton

Humes AG (1987) Copepoda from deep-sea hydrothermal vents. Bull Mar Sci 41:645-788

Humes AG (1999) Collocherides brychius, a new species (Copepoda: Siphonostomatoida: Asterocheridae) from a deep-water hydrothermal site in the northeastern Pacific. Proc Biol Soc Wash 112:181188

Humes AG, Dojiri M (1980) A siphonostome copepod associated with a vestimentiferan from the Galapagos Rift and the East Pacific Rise. Proc Biol Soc Wash 93:697-707

Huntley ME, Lopez MDG (1992) Temperature-dependent production of marine copepods: a global synthesis. Am Nat 140:201-242

Ichino MC, Clark MR, Drazen JC, Jamieson A, Jones DOB, Martin AP, Rowden AA, Shank TM, Yancey PH, Ruhl HA (2015) The distribution of benthic biomass in hadal trenches: a modelling approach to investigate the effect of vertical and lateral organic matter transport to the seafloor. Deep Sea Res I Oceanogr Res Pap 100:21-33

Ikehara K, Kanamatsu T, Nagahashi Y, Strasser M, Fink H, Usami K, Irino T, Wefer G (2016) Documenting large earthquakes similar to the 2011 Tohoku-oki earthquake from sediments deposited in the Japan Trench over the past 1500 years. Earth Planet Sci Lett 445:48 56

Iliffe TM, Kornicker LS (2009) Worldwide diving discoveries of living fossil animals from the depths of anchialine and marine caves. In: Lang MA, Macintyre IG, Rützler K (eds) Proceedings of the Smithsonian Marine Science Symposium. Smithsonian Institution Scholarly Press, Washington DC, pp 269-280

Ingels J, Vanreusel A (2013) The importance of different spatial scales in determining structural and functional characteristics of deep-sea infauna communities. Biogeosciences 10:4547-4563

Ingels J, Vanhove S, De Mesel I, Vanreusel A (2006) The biodiversity and biogeography of the free-living nematode genera Desmodora and Desmodorella (family Desmodoridae) at both sides of the Scotia Arc. Polar Biol 29:936-949

Ingels J, Kiriakoulakis K, Wolff GA, Vanreusel A (2009) Nematode diversity and its relation to the quantity and quality of sedimentary organic matter in the deep Nazaré Canyon, Western Iberian Margin. Deep Sea Res I Oceanogr Res Pap 56:1521-1539

Ingels J, Van den Driessche P, De Mesel I, Vanhove S, Moens T, Vanreusel A (2010) Preferred use of bacteria over phytoplankton by deep-sea nematodes in polar regions. Mar Ecol Prog Ser 406: 121-133

Ingels J, Billett DSM, Kiriakoulakis K, Wolff GA, Vanreusel A (2011a) Structural and functional diversity of Nematoda in relation with environmental variables in the Setúbal and Cascais canyons, Western Iberian Margin. Deep Sea Res II Top Stud Oceanogr 58: 2354-2368

Ingels J, Billett DSM, Van Gaever S, Vanreusel A (2011b) An insight into the feeding ecology of deep-sea canyon nematodes - results from field observations and the first in-situ 13C feeding experiment in the Nazaré Canyon. J Exp Mar Biol Ecol 396:185-193

Ingels J, Tchesunov AV, Vanreusel A (2011c) Meiofauna in the Gollum Channels and the Whittard Canyon, Celtic Margin-how local environmental conditions shape nematode structure and function. PLoS One 6:e20094

Ingels J, Vanreusel A, Romano C, Coenjaerts J, Mar Flexas M, Zúñiga D, Martin D (2013) Spatial and temporal infaunal dynamics of the Blanes submarine canyon-slope system (NW Mediterranean); changes in nematode standing stocks, feeding types and genderlife stage ratios. Prog Oceanogr 118:159-174

Ingels J, Hauquier F, Raes M, Vanreusel A (2014) Antarctic free-living marine nematodes. In: De Broyer C, Koubbi P, Griffiths HJ, Raymond B, d'Udekem d'Acoz C, Van de Putte AP, Danis B, David B, Grant S, Gutt J, Held C, Hosie G, Huettmann F, Post A, Ropert-Coudert Y (eds) Biogeographic atlas of the Southern Ocean. Scientific Committee on Antarctic Research, Cambridge, pp 83-87

Ingole B, Singh R (2010) Biodiversity and community structure of freeliving marine nematodes from the Larsemann Ice Shelf, East Antarctica. Curr Sci 99:1413-1419

Itoh M, Kawamura K, Kitahashi T, Kojima S, Katagiri H, Shimanaga M (2011) Bathymetric patterns of meiofaunal abundance and biomass associated with the Kuril and Ryukyu trenches, western North Pacific Ocean. Deep Sea Res I Oceanogr Res Pap 58:86-97

Ivanenko VN, Defaye D (2004a) A new genus and species of deep-sea cyclopoid (Crustacea, Copepoda, Cyclopinidae) from the MidAtlantic Ridge (Azores Triple Junction, Lucky Strike). Zoosystema 26(1):49-64

Ivanenko VN, Defaye D (2004b) A new and primitive genus and species of deep-sea Tegastidae (Crustacea, Copepoda, Harpacticoida) from the Mid-Atlantic Ridge, $37^{\circ} \mathrm{N}$ (Azores Triple Junction, Lucky Strike). Cah Biol Mar 45(3):255-268

Ivanenko VN, Defaye D (2006) Copepoda. In: Desbruyères D, Segonzac M, Bright M (eds) Handbook of deep-sea hydrothermal vent fauna. Denisia, Linz, pp 316-355

Ivanenko VN, Ferrari FD (2013) New species of Stygiopontius (Copepoda: Siphonostomatoida: Dirivultidae) from a deep-sea hydrothermal volcano in the New Ireland Fore-Arc system (Papua New Guinea). J Mar Biol Assoc UK 93(7):180-1812

Ivanenko VN, Martinez Arbizu P (2016) A new deep-sea genus and species of the family Ecbathyriontidae (Copepoda: Siphonostomatoida) from the Gorda Ridge (North Pacific Ocean). Mar Biodivers. https://doi.org/10.1007/s12526-016-0570-6

Ivanenko VN, Defaye D, Cuoc C (2007a) A new calanoid copepod (Spinocalanidae) swarming at a cold seep site on the Gabon continental margin (Southeast Atlantic). Cah Biol Mar 48:37-54

Ivanenko VN, Martínez Arbizu P, Stecher J (2007b) Lecithotrophic nauplius of the family Dirivultidae (Copepoda; Siphonostomatoida) hatched on board over the Mid-Atlantic Ridge ( $\left.5^{\circ} \mathrm{S}\right)$. Mar Ecol 28(1):49-53

Ivanenko V, Ferrari FD, Defaye D, Sarradin PM, Sarrazin J (2011a) Description, distribution and microhabitats of a new species of Tisbe (Copepoda: Harpacticoida: Tisbidae) from a deep-sea hydrothermal vent field at the Mid-Atlantic Ridge (37 degrees N, Lucky Strike). Cah Biol Mar 52(1):89-106

Ivanenko VN, Defaye D, Segonzac M, Khripounoff A, Sarrazin J, Ferrari FD (2011b) A new species of Exrima, synonymy of four species of Aphotopontius, Stygiopontius and Rhogobius, and record of first copepodid stage of Dirivultidae (Copepoda: Siphonostomatoida) from deep-sea hydrothermal vents of the East Pacific Rise $\left(13^{\circ} \mathrm{N}\right)$. J Mar Biol Assoc UK 91(7):1547-1559

Ivanenko VN, Corgosinho PH, Ferrari F, Sarradin PM, Sarrazin J (2012) Microhabitat distribution of Smacigastes micheli (Copepoda: Harpacticoida: Tegastidae) from deep-sea hydrothermal vents at the Mid-Atlantic Ridge, $37^{\circ} \mathrm{N}$ (Lucky Strike), with a morphological description of its nauplius. Mari Ecol 33(2):246-256

James TC, Usher J, Campbell S, Bond U (2008) Lager yeasts possess dynamic genomes that undergo rearrangements and gene amplification in response to stress. Curr Genet 53:139-152 
Jamieson AJ (2015) The hadal zone: life in the deepest oceans. Cambridge University Press, Cambridge, 372 pp

Jamieson AJ, Fujii T, Mayor DJ, Solan M, Priede IG (2010) Hadal trenches: the ecology of the deepest places on Earth. Trends Ecol Evol 25: 190-197

Janssen A, Chevaldonné P, Martínez Arbizu P (2013) Meiobenthic copepod fauna of a marine cave (NW Mediterranean) closely resembles that of deep-sea communities. Mar Ecol Prog Ser 479:99-113

Jaume D, Boxshall GA (2009) Life in extreme ocean environments: anchialine caves. In: Duarte CM, Helgueras AL (eds) Marine ecology. EOLSS, pp 230-251

Jørgensen A, Boesgaard TM, Møbjerg N, Kristensen RM (2014) The tardigrade fauna of Australian marine caves: with descriptions of nine new species of Arthrotardigrada. Zootaxa 3802:401-443

Jorissen FJ, Buzas MA, Culver SJ, Kuehl SA (1994) Vertical distribution of living benthic foraminifera in submarine canyons off New Jersey. J Foram Res 24:28-36

Juan C, Guzik MT, Jaume D, Cooper SJB (2010) Evolution in caves: Darwin's 'wrecks of ancient life' in the molecular era. Mol Ecol 19: 3865-3880

Juniper SK, Sibuet M (1987) Cold seep benthic communities in Japan subduction zones: spatial organization, trophic strategies and evidence for temporal evolution. Mar Ecol Prog Ser 40:115-126

Kaya M, De Smet WH, Fontaneto D (2010) Survey of moss-dwelling bdelloid rotifers from middle Arctic Spitsbergen (Svalbard). Polar Biol 33:833-842

Kaiser MJ, Attrill MJ, Jennings S, Thomas DN, Barnes DKA, Brierley AS, Polunin NVC, Raffaelli DG, Williams PJLB (2005) Marine ecology: processes, systems, and impacts. Oxford University Press, Oxford

Kaminski MA (1985) Evidence for control of abyssal agglutinated foraminiferal community structure by substrate disturbance: results from the HEBBLE area. Mar Geol 66:113-131

Kaminski MA, Schröder CJ (1987) Environmental analysis of deep-sea agglutinated foraminifera: can we distinguish tranquil from disturbed environments? Gulf Coast Section SEPM Foundation Eighth Annual Research Conference. Selected papers and illustrated abstracts, pp 90-93

Kamykowski D, Zentara S-J (1990) Hypoxia in the world ocean as recorded in the historical data set. Deep Sea Res A Oceanogr Res Pap 37:1861-1874

Khusid TA (1979) The distribution of benthic foraminifera in the KurileKamchatka trough area. Soviet J Mar Biol 5:168-173

Kiko R, Werner I, Wittmann A (2009) Osmotic and ionic regulation in response to salinity variations and cold resistance in the Arctic under-ice amphipod Apherusa glacialis. Polar Biol 32:393-398

Kiriakoulakis K, Blackbird S, Ingels J, Vanreusel A, Wolff GA (2011) Organic geochemistry of submarine canyons: the Portuguese Margin. Deep Sea Res II Top Stud Oceanogr 58:2477-2488

Kirsteuer E (1964) Zur Kenntnis der Kinorhynchen Venezuelas. Zool Anz 173:388-393

Kitahashi T, Kawamura K, Veit-Köhler G, Danovaro R, Tietjen J, Kojima S, Shimanaga M (2012) Assemblages of Harpacticoida (Crustacea: Copepoda) from the Ryukyu and Kuril Trenches, north-west Pacific Ocean. J Mar Biol Assoc UK 92:275-286

Kitahashi T, Kawamura K, Kojima S, Shimanaga M (2013) Assemblages gradually change from bathyal to hadal depth: a case study on harpacticoid copepods around the Kuril Trench (north-west Pacific Ocean). Deep Sea Res I Oceanogr Res Pap 74:39-47

Kitahashi T, Watanabe H, Ikehara K, Jenkins RG, Kojima S, Shimanaga M (2016) Deep-sea meiofauna off the Pacific coast of Tohoku and other trench slopes around Japan: a comparative study before and after the 2011 off the Pacific coast of Tohoku Earthquake. J Oceanography 72:129-139
Kitazato H (1996) Benthic foraminifera associated with cold seepages: discussion of their faunal characteristics and adaptations. Fossils 60: $48-52$

Kitazato H, Uematsui K, Todo Y, Gooday AJ (2009) New species of Leptohalysis (Rhizaria, Foraminifera) from an extreme hadal site in the western Pacific Ocean. Zootaxa 2059:23-32

Kito K, Aryuthaka C (2006) New mouthless nematode of the genus Parastomonema Kito, 1989 (Nematoda: Siphonolaimidae) from a mangrove forest on the coast of Thailand, and erection of the new subfamily Astomonematinae within the Siphonolaimidae. Zootaxa 1177:39-49

Koho KA, Piña-Ochoa E (2012) Benthic foraminifera: inhabitants of lowoxygen environments. In: Altenbach AV, Bernhard JM, Seckbach J (eds) Anoxia. Evidence for eukaryote survival and paleontological strategies. Springer, Dordrecht, pp 249-285

Koho KA, Kouwenhoven TJ, de Stigter HC, van der Zwaan GJ (2007) Benthic foraminifera in the Nazaré Canyon, Portuguese continental margin: sedimentary environments and disturbance. Mar Micropaleontol 66:27-51

Kristensen E, Andersen FØ, Kofoed LH (1988) Preliminary assessment of benthic community metabolism in a south-east Asian mangrove swamp. Mar Ecol Prog Ser 48:137-145

Laakmann S, Gerdts G, Erler R, Knebelsberger T, Martínez Arbizu P, Raupach MJ (2013) Comparison of molecular species identification for North Sea calanoid copepods (Crustacea) using proteome fingerprints and DNA sequences. Mol Ecol Resour 13:862-876

Lambshead PJD, Tietjen J, Glover A, Ferrero T, Thistle D, Gooday AJ (2001) Impact of large-scale natural physical disturbance on the diversity of deep-sea North Atlantic nematodes. Mar Ecol Prog Ser 214:121-126

Lampadariou N, Kalogeropoulou V, Sevastou K, Keklikoglou K, Sarrazin J (2013) Influence of chemosynthetic ecosystems on nematode community structure and biomass in the deep eastern Mediterranean Sea. Biogeosciences 10:5381-5398

Laurent MCZ, Gros O, Brulport J-P, Gaill F, Le Bris N (2009) Sunken wood habitat for thiotrophic symbiosis in mangrove swamps. Mar Environ Res 67:83-88

Leduc D, Rowden AA, Nodder SD, Berkenbusch K, Probert PK, Hadfield MG (2014) Unusually high food availability in Kaikoura Canyon linked to distinct deep-sea nematode community. Deep Sea Res II Top Stud Oceanogr 104:310-318

Leduc D, Rowden AA, Glud RN, Wenzhöfer F, Kitazato H, Clark MR (2016) Comparison between infaunal communities of the deep floor and edge of the Tonga Trench: possible effects of differences in organic matter supply. Deep Sea Res I Oceanogr Res Pap 116: 264-275

Lee H, Vanhove S, Peck LS, Vincx M (2001) Recolonisation of meiofauna after catastrophic iceberg scouring in shallow Antarctic sediments. Polar Biol 24:918-925

Legendre L, Ackley SF, Dieckmann GS, Gulliksen B, Horner R, Hoshiai T, Melnikov IA, Reeburgh WS, Spindler M (1992) Ecology of sea ice biota. Global significance. Polar Biol 12:429-444

Lemche H, Hansen B, Madsen FJ, Tendal OS, Wolff T (1976) Hadal life as analysed from photographs. Vidensk Meddr Dansk Naturh Foren 139:263-336

Levin LA (2003) Oxygen minimum zone benthos: adaptation and community response to hypoxia. Oceanogr Mar Biol 41:1-45

Levin LA (2005) Ecology of cold seep sediments: interactions of fauna with flow, chemistry and microbes. In: Gibson RN, Atkinson RJA, Gordon JDM (eds) Oceanography and marine biology — an annual review, vol 43. Crc Press-Taylor \& Francis Group, Boca Raton, pp $1-46$

Levin LA, Etter RJ, Rex MA, Gooday AJ, Smith CR, Pineda J, Stuart CT, Hessler RR, Pawson D (2001) Environmental influences on regional deep-sea species diversity. Annu Rev Ecol Syst 32:51-93 
Levin LA, Ekau W, Gooday AJ, Jorissen F, Middelburg JJ, Naqvi SWA, Neira C, Rabalais NN, Zhang J (2009) Effects of natural and humaninduced hypoxia on coastal benthos. Biogeosciences 6:2063-2098

Limén H, Levesque C, Juniper SK (2007) POM in macro-/meiofaunal food webs associated with three flow regimes at deep-sea hydrothermal vents on Axial Volcano, Juan de Fuca Ridge. Mar Biol 153: 129-139

Limén H, Stevens CJ, Bourass Z, Juniper SK (2008) Trophic ecology of siphonostomatoid copepods at deep-sea hydrothermal vents in the northeast Pacific. Mar Ecol Prog Ser 359:161-170

Lobegeier MK, Sen Gupta BK (2008) Foraminifera of hydrocarbon seeps, Gulf of Mexico. J Foramin Res 38:93-116

Login FH, Balmand S, Vallier A, Vincent-Monégat C, Vigneron A, Weiss-Gayet M, Rochat D, Heddi A (2011) Antimicrobial peptides keep insect endosymbionts under control. Science 334:362-365

Lønne OJ, Gulliksen B (1991) On the distribution of sympagic macrofauna in the seasonally ice covered Barents Sea. Polar Biol 11:457469

Lundsten L, Schlining KL, Frasier K, Johnson SB, Kuhnz LA, Harvey JB, Clague G, Vrijenhoek RC (2010) Time-series analysis of six whale-fall communities in Monterey Canyon, California, USA. Deep Sea Res I Oceanogr Res Pap 57:1573-1584

Mackensen A, Wollenburg J, Licari L (2006) Low $813 \mathrm{C}$ in tests of live epibenthic and endobenthic foraminifera at a site of active methane seepage. Paleoceanography 21(2). https://doi.org/10.1029/ 2005PA001196

Mallon J, Glock N, Schönfeld J (2012) The response of benthic foraminifera to low-oxygen conditions of the Peruvian oxygen minimum zone. In: Altenbach AV, Bernhard JM, Seckbach J (eds) Anoxia. Evidence for eukaryote survival and paleontological strategies. Springer, Dordrecht, pp 305-321

Marchand C, Baltzer F, Lallier-Vergès E, Albéric P (2004) Pore-water chemistry in mangrove sediments: relationship with species composition and developmental stages (French Guiana). Mar Geol 208: 361-381

Mare MF (1942) A study of a marine benthic community with special reference to the micro-organisms. J Mar Biol Assoc UK 25:517-554

Maróti G, Kereszt A, Kondorosi E, Mergaert P (2011) Natural roles of antimicrobial peptides in microbes, plants and animals. Res Microbiol 162:363-374

Martin JB, Day SA, Rathburn AE, Perez ME, Mahn C, Gieskes J (2004) Relationships between the stable isotopic signatures of living and fossil foraminifera in Monterey Bay, California. Geochem Geophys Geosyst 5:Q04004. https://doi.org/10.1029/2003GC000629

Martin RA, Nesbitt EA, Campbell KA (2010) The effects of anaerobic methane oxidation on benthic foraminiferal assemblages and stable isotopes on the Hikurangi Margin of eastern New Zealand. Mar Geol 272:270-284

Martínez García A, María Palmero A, del Carmen Brito M, Núñez J, Worsaae K (2009) Anchialine fauna of the Corona lava tube (Lanzarote, Canary Islands): diversity, endemism and distribution. Mar Biodivers 39:169-182

Matthijs S, Tack J, van Speybroeck D, Koedam N (1999) Mangrove species zonation and soil redox state, sulphide concentration and salinity in Gazi Bay (Kenya), a preliminary study. Mangroves Salt Marshes 3:243-249

Maurin LC, Himmel D, Mansot J-L, Gros O (2010) Raman microspectrometry as a powerful tool for a quick screening of thiotrophy: an application on mangrove swamp meiofauna of Guadeloupe (F.W.I.) Mar Environ Res 69:382-389

Maykut GA (1985) Chapter 2. The ice environment. In: Horner RA (ed) Sea ice biota. CRC Press, Boca Raton, pp 21-82

McKee KL (1993) Soil physicochemical patterns and mangrove species distribution-reciprocal effects? J Ecol 81:477-487
McMullin ER, Bergquist DC, Fisher CR (2000) Metazoans in extreme environments: adaptations of hydrothermal vent and hydrocarbon seep fauna. Gravitational Space Biol Bull 13:13-24

Mestre NC, Calado R, Soares AMVM (2014) Exploitation of deep-sea resources: the urgent need to understand the role of high pressure in the toxicity of chemical pollutants to deep-sea organisms. Environ Pollut 185:369-371

Michel C, Nielsen TG, Nozais C, Gosselin M (2002) Significance of sedimentation and grazing by ice micro- and meiofauna for carbon cycling in annual sea ice (northern Baffin Bay). Aquat Microb Ecol 30:57-68

Middelburg JJ, Nieuwenhuize J, Slim FJ, Ohowa B (1996) Sediment biogeochemistry in an East African mangrove forest (Gazi Bay, Kenya). Biogeochemistry 34:133-155

Modig H, Olafsson E (1998) Responses of Baltic benthic invertebrates to hypoxic events. J Exp Mar Biol Ecol 229:133-148

Mullineaux LS, Le Bris N, Mills SW, Henri P, Bayer SR, Secrist RG, Siu $N$ (2012) Detecting the influence of initial pioneers on succession at deep-sea vents. PLoS One 7(12):e50015

Murrell MC, Fleeger JW (1989) Meiofauna abundance on the Gulf of Mexico continental shelf affected by hypoxia. Cont Shelf Res 9: 1049-1062

Nagelkerken I, Blaber SJM, Bouillon S, Green P, Haywood M, Kirton LG, Meynecke JO, Pawlik J, Penrose HM, Sasekumar A, Somerfield PJ (2008) The habitat function of mangroves for terrestrial and marine fauna: a review. Aquat Bot 89:155-185

Netto SA, Gallucci F (2003) Meiofauna and macrofauna communities in a mangrove from the island of Santa Catarina, South Brazil. Hydrobiologia 505:159-170

Neuhaus B (2013) Kinorhyncha (=Echinodera). In: Schmidt-Rhaesa A (ed) Handbook of zoology. Gastrotricha, Cycloneuralia and Gnathifera, volume 1: Nematomorpha, Priapulida, Kinorhyncha, Loricifera. De Gruyter, Berlin, pp 181-348

Neuhaus B, Sørensen MV (2013) Populations of Campyloderes sp. (Kinorhyncha, Cyclorhagida): one global species with significant morphological variation? Zool Anz 252:48-75

Neves RC, Gambi C, Danovaro R, Kristensen RM (2014) Spinoloricus cinziae (Phylum Loricifera), a new species from a hypersaline anoxic deep basin in the Mediterranean Sea. Syst Biodivers 12:489 502

Nicholas W, Sørenson MV (2009) Kinorynchs from sea-grass beds in south eastern Australia - with notes on a new collecting method. Wetlands (Australia) 25:20-24

Nicholas WL, Elek JA, Stewart AC, Marples TG (1991) The nematode fauna of a temperate Australian mangrove mudflat; its population density, diversity and distribution. Hydrobiologia 209:13-27

Nickerson NH, Thibodeau FR (1985) Association between pore water sulfide concentrations and the distribution of mangroves. Biogeochemistry 1:183-192

Nomaki H, Mochizuki T, Kitahashi T, Nunoura T, Arai K, Toyofuku T, Tanaka G, Shigeno S, Tasumi E, Fujikura K, Watanabe S (2016) Effects of mass sedimentation events after the 2011 off the Pacific coast of Tohoku Earthquake on benthic prokaryotes and meiofauna inhabiting the upper bathyal sediments. J Oceanogr 72:113-128

Ólafsson E, Carlström S, Ndaro SG (2000) Meiobenthos of hypersaline tropical mangrove sediment in relation to spring tide inundation. Hydrobiologia 426:57-64

Olu K, Sibuet M, Harmegnies F, Foucher J-P, Fiala-Médioni A (1996) Spatial distribution of diverse cold seep communities living on various diapiric structures of the southern Barbados prism. Prog Oceanog 38:347-376

Olu K, Lance S, Sibuet M, Henry P, Fiala-Médioni A, Dinet A (1997) Cold seep communities as indicators of fluid expulsion patterns through mud volcanoes seaward of the Barbados accretionary prism. Deep Sea Res I Oceanogr Res Pap 44:811-841 
Omer-Cooper J (1957) Deux nouvelles espèces de Kinorhyncha en provenance de L'Afrique du Sud. Bull Mens Soc Linn Lyon 26:213-216

Ostmann A, Nordhaus I, Sørensen MV (2012) First recording of kinorhynchs from Java, with the description of a new brackish water species from a mangrove-fringed lagoon. Mar Biodivers 42:79-91

Ott J, Rieger G, Rieger R, Enderes F (1982) New mouthless interstitial worms from the sulfide system: symbiosis with prokaryotes. Mar Ecol 3:313-333

Ott J, Bright M, Bulgheresi S (2004) Marine microbial thiotrophic ectosymbioses. Oceanogr Mar Biol Annu Rev 42:95-118

Otti O, Tragust S, Feldhaar H (2014) Unifying external and internal immune defences. Trends Ecol Evol 29:625-634

Palacin C, Masalles D (1986) Some data on the meiofauna of an underwater cave of the island of Majorca, Spain. Publ Dep Zool Barcelona $12: 15-26$

Palacín C, Gili JM, Martín D (1992) Evidence for coincidence of meiofauna spatial heterogeneity with eutrophication processes in a shallow-water Mediterranean bay. Estuarine Coast Shelf Sci 35:116

Panieri G (2006) Foraminiferal response to an active methane seep environment: a case study from the Adriatic Sea. Mar Micropaleontol 61:116-130

Papot C, Massol F, Jollivet D, Tasiemski A (2017) Antagonistic evolution of an antibiotic and its molecular chaperone: how to maintain a vital ectosymbiosis in a highly fluctuating habitat. Sci Rep 7:1454

Pardos F, Herranz M, Sánchez N (2016) Two sides of a coin: the phylum Kinorhyncha in Panama. II) Pacific Panama. Zool Anz 265:26-47

Pascal PY, Dubois S, Boschker HTS, Gros O (2014) Trophic role of large benthic sulfur bacteria in mangrove sediment. Mar Ecol Prog Ser 516:127-138

Pasotti F, De Troch M, Raes M, Vanreusel A (2012) Feeding ecology of shallow water meiofauna: insights from a stable isotope tracer experiment in Potter Cove, King George Island, Antarctica. Polar Biol 35:1629-1640

Pasotti F, Convey P, Vanreusel A (2014) Potter Cove, West Antarctic Peninsula, shallow water meiofauna: a seasonal snapshot. Antarct Sci 26(5):554-562

Pasotti F, Saravia LA, De Troch M, Tarantelli MS, Sahade R, Vanreusel A (2015) Benthic trophic interactions in an Antarctic shallow water ecosystem affected by recent glacier retreat. PLoS One 10(11): $\mathrm{e} 0141742$

Pavlyuk ON, Trebukhova YA, Tarasov VG (2009) The impact of implanted whale carcass on nematode communities in shallow water area of Peter the Great Bay (East Sea). Ocean Sci J 44:181-188

Pawlowski J, Fahrni J, Lecroq B, Longet D, Cornelius N, Excoffier L, Cedhagen T, Gooday AJ (2007) Bipolar gene flow in deep-sea benthic foraminifera. Mol Ecol 16:4089-4096

Pawlowski J, Majewski W, Longet D, Guiard J, Cedhagen T, Gooday AJ, Korsun S, Habura AA, Bowser SS (2008) Genetic differentiation between Arctic and Antarctic monothalamous foraminiferans. Polar Biol 31:1205-1216

Perez-Cruz LL, Machain-Castillo ML (1990) Benthic foraminifera of the oxygen minimum zone, continental shelf of the Gulf of Tehuantepec, Mexico. J Foramin Res 20:312-325

Pesta O (1959) Harpacticoiden (Crust. Copepoda) aus submarinen Höhlen und den Benachbarten litoralbezirken am Kap von Sorrent (Neapel). Pubbl Stn Zool Napoli 30:95-177

Phleger FB, Soutar A (1973) Production of benthic foraminifera in three east Pacific oxygen minima. Micropaleontology 19:110-115

Piña-Ochoa E, Høgslund S, Geslin E, Cedhagen T, Revsbech NP, Nielsen LP, Schweizer M, Jorissen F, Rysgaard S, Risgaard-Petersen N (2010a) Widespread occurrence of nitrate storage and denitrification among Foraminifera and Gromiida. Proc Natl Acad Sci U S A 107: $1148-1153$

Piña-Ochoa E, Koho KA, Geslin E, Risgaard-Petersen N (2010b) Survival and life strategy of the foraminiferan Globobulimina turgida through nitrate storage and denitrification. Mar Ecol Prog Ser 417:39-49

Pinto TK, Austen MCV, Warwick RM, Somerfield PJ, Esteves AM, Castro FJV, Fonseca-Genevois VG, Santos PJP (2013) Nematode diversity in different microhabitats in a mangrove region. Mar Ecol 34:257-268

Plum C, Gollner S, Martínez-Arbizu P, Bright M (2015) Diversity and composition of the copepod communities associated with megafauna around a cold seep in the Gulf of Mexico with remarks on species biogeography. Mar Biodivers 45:419-432

Plum C, Pradillon F, Fujiwara Y, Sarrazin J (2017) Copepod colonization of organic and inorganic substrata at a deep-sea hydrothermal vent site on the Mid-Atlantic Ridge. Deep Sea Res II Top Stud Oceanogr 137:335-348

Puig P, Canals M, Company JB, Martín J, Amblas D, Lastras G, Palanques A, Calafat AM (2012) Ploughing the deep sea floor. Nature 489:286-289

Pusceddu A, Gambi C, Corinaldesi C, Scopa M, Danovaro R (2014) Relationships between meiofaunal biodiversity and prokaryotic heterotrophic production in different tropical habitats and oceanic regions. PLoS One 9(3):e91056

Rabalais NN, Turner RE, Wiseman WJ Jr (2002) Gulf of Mexico hypoxia, aka "the dead zone". Annu Rev Ecol Syst 33:235-263

Rabalais NN, Diaz RJ, Levin LA, Turner RE, Gilbert D, Zhang J (2010) Dynamics and distribution of natural and human-caused hypoxia. Biogeosciences 7:585-619

Ramalho SP, Adão H, Kiriakoulakis K, Wolff GA, Vanreusel A, Ingels J (2014) Temporal and spatial variation in the Nazaré Canyon (Western Iberian Margin): inter-annual and canyon heterogeneity effects on meiofauna biomass and diversity. Deep Sea Res I Oceanogr Res Pap 83:102-114

Ramirez-Llodra EZ, Brandt A, Danovaro R, De Mol B, Escobar E, German CR, Levin LA, Martinez Arbizu P, Menot L, BuhlMortensen P, Narayanaswamy BE (2010) Deep, diverse and definitely different: unique attributes of the world's largest ecosystem. Biogeosciences 7:2851-2899

Rathburn AE, Levin LA, Held Z, Lohmann KC (2000) Benthic foraminifera associated with cold methane seeps on the northern California margin: ecology and stable isotopic composition. Mar Micropaleontol 38:247-266

Rathburn AE, Pérez ME, Martin JB, Day SA, Mahn C, Gieskes J, Ziebis W, Williams D, Bahls A (2003) Relationships between the distribution and stable isotopic composition of living benthic foraminifera and cold methane seep biogeochemistry in Monterey Bay, California. Geochem Geophys Geosyst 4:1-28

Revkov NK, Sergeeva NG (2004) Current state of the zoobenthos at the Crimean shores of the Black Sea. In: Öztürk B, Mokievsky VO, Topaloğlu B (eds) International workshop on Black Sea benthos. Turkish Marine Research Foundation, TÜDAV, Istanbul, pp 186214

Rex MA, Etter RJ, Morris JS, Crouse J, McClain CR, Johnson NA, Stuart CT, Deming JW, Thies R, Avery R (2006) Global bathymetric patterns of standing stock and body size in the deep-sea benthos. Mar Ecol Prog Ser 317:1-8

Richardson MJ, Wimbush M, Mayer L (1981) Exceptionally strong nearbottom flows on the continental rise of Nova Scotia. Science 213: $887-888$

Riedl R (1966) Biologie der Meereshöhlen. Paul Parey, Hamburg

Riemann F, Sime-Ngando T (1997) Note on sea-ice nematodes (Monhysteroidea) from Resolute Passage, Canadian high Arctic. Polar Biol 18:70-75

Riera R, Tuya F, Sacramento A, Ramos E, Rodríguez M, Monterroso Ó (2011) The effects of brine disposal on a subtidal meiofauna community. Estua Coast Shelf Sci 93:359-365

Riera R, Monterroso Ó, Núñez J, Martínez A (2016) Distribution of meiofaunal abundances in a marine cave complex with secondary 
openings and freshwater filtrations. Mar Biodivers. https://doi.org/ 10.1007/s12526-016-0586-y

Riesch R, Plath M, Schlupp I (2010) Toxic hydrogen sulfide and dark caves: life-history adaptations in a livebearing fish (Poecilia mexicana, Poeciliidae). Ecology 91(5):1494-1505

Risgaard-Petersen N, Langezaal AM, Ingvardsen S, Schmid MC, Jetten MSM, den Camp HJMO, Derksen JWM, Piña-Ochoa E, Eriksson SP, Nielsen LP, Revsbech NP, Cedhagen T, van der Zwaan GJ (2006) Evidence for complete denitrification in a benthic foraminifer. Nature 443:93-96

Ritchie H, Jamieson AJ, Piertney SB (2017) Population genetic structure of two congeneric deep-sea amphipod species from geographically isolated hadal trenches in the Pacific Ocean. Deep Sea Res I Oceanogr Res Pap 119:50-57

Ritt B, Sarrazin J, Caprais J-C, Noël P, Gauthier O, Pierre C, Henry P, Desbruyères D (2010) First insights into the structure and environmental setting of cold-seep communities in the Marmara Sea. Deep Sea Res I Oceanogr Res Pap 57:1120-1136

Robinson CA, Bernhard JM, Levin LA, Mendoza GF, Blanks JK (2004) Surficial hydrocarbon seep infauna from the Blake ridge (Atlantic Ocean, $2150 \mathrm{~m}$ ) and the Gulf of Mexico (690-2240 m). Mar Ecol 25:313-336

Román S, Vanreusel A, Romano C, Ingels J, Puig P, Company JB, Martin D (2016) High spatiotemporal variability in meiofaunal assemblages in Blanes Canyon (NW Mediterranean) subject to anthropogenic and natural disturbances. Deep Sea Res I Oceanogr Res Pap 117: $70-83$

Romano C, Coenjaerts J, Mar Flexas M, Zúñiga D, Vanreusel A, Company JB, Martin D (2013) Spatial and temporal variability of meiobenthic density in the Blanes submarine canyon $(\mathrm{NW}$ Mediterranean). Prog Oceanogr 118:144-158

Rosli N, Leduc D, Rowden AA, Probert PK (this issue) Review of recent trends in ecological studies of deep-sea meiofauna, with focus on patterns and processes at small to regional spatial scales. Mar Biodivers

Rothschild LJ, Mancinelli RL (2001) Life in extreme environments. Nature 409:1092-1101

Rouse GW, Goffredi SK, Vrijenhoek RC (2004) Osedax: bone-eating marine worms with dwarf males. Science 305:668-671

Sabbatini A, Morigi C, Negri A, Gooday AJ (2002) Soft-shelled benthic foraminifera from a hadal site (7800 $\mathrm{m}$ water depth) in the Atacama trench (SE Pacific): preliminary observations. J Micropalaeontol 21: $131-135$

Saenger P (2002) Mangrove ecology, silviculture and conservation. Springer, Netherlands

Saidova KhM (1970) Benthic foraminifers of the Kurile-Kamchatka Trench area. In: Bogorov VG (ed) Fauna of the Kurile-Kamchatka Trench and its environment. Academy of Sciences of the USSR, Proceedings of the Institute of Oceanology 86:144-173

Saidova KhM (1975) Benthonic foraminifera of the Pacific Ocean. Three volumes. P.P. Shirshov Institut Okeanologii, Akademiya Nauk SSSR, Moscow

Salzet M, Tasiemski A, Cooper E (2006) Innate immunity in lophotrochozoans: the annelids. Curr Pharm Des 12:3043-3050

Salzman NH, Hung K, Haribhai D, Chu H, Karlsson-Sjöberg J, Amir E, Teggatz P, Barman M, Hayward M, Eastwood D, Stoel M, Zhou Y, Sodergren E, Weinstock GM, Bevins CL, Williams CB, Bos NA (2009) Enteric defensins are essential regulators of intestinal microbial ecology. Nat Immunol 11:76-82

Sánchez N, Pardos F, Sørensen MV (2014a) Deep-sea Kinorhyncha: two new species from the Guinea Basin, with evaluation of an unusual male feature. Org Divers Evol 14:349-361

Sánchez N, Pardos F, Sørensen MV (2014b) A new kinorhynch genus, Mixtophyes (Kinorhyncha: Homalorhagida), from the Guinea Basin deep-sea, with new data on the family Neocentrophyidae. Helgol Mar Res 68:221-239
Sandulli R, Gallo D'addabbo M, De Lucia Morone MR, D’Addabbo R, Pietanza R, De Zio Grimaldi S (1999) Preliminary investigations on meiofauna of two caves in San Domino Island (Tremiti Archipelago, Adriatic Sea). Biol Mar Medit 6:437-440

Santos PJP, Botter-Carvalho M, do Nascimento-Júnior AB, Marinho RGC, Carvalho PVVC, Valebça APMC (2009) Response of estuarine meiofauna assemblage to effects of fertilizer enrichment used in the sugar cane monoculture. Pernambuco, Brazil. Braz J Oceanogr $57: 43-55$

Sarma ALN, Wilsanand V (1994) Littoral meiofauna of Bhitarkanika mangroves of river Mahanadi system, east coast of India. Indian J Mar Sci 23:221-224

Sarradin PM, Caprais JC, Riso R, Kerouel R, Aminot A (1999) Chemical environment of the hydrothermal mussel communities in the Lucky Strike and Menez Gwen vent fields, Mid Atlantic Ridge. Cah Biol Mar 40:93-104

Sarrazin J, Legendre P, De Busserolles F, Fabri MC, Guilini K, Ivanenko VN, Morineaux M, Vanreusel A, Sarradin PM (2015) Biodiversity patterns, environmental drivers and indicator species on a hightemperature hydrothermal edifice, Mid-Atlantic Ridge. Deep Sea Res II Top Stud Oceanogr 121:177-192

Schikorski D, Cuvillier-Hot V, Leippe M, Macagno E, Salzet M, Tasiemski A (2008) The medicinal leech as a model for studying the antimicrobial response of the central nervous system. J Immunol 181:1083-1095

Schmidt C, Martínez Arbizu P (2015) Unexpectedly higher metazoan meiofauna abundances in the Kuril-Kamchatka Trench compared to the adjacent abyssal plain. Deep Sea Res II Top Stud Oceanogr 111:60-75

Schmidt-Rhaesa A, Rothe BH, Martínez AG (2013) Tubiluchus lemburgi, a new species of meiobenthic Priapulida. Zool Anz 253(2):158-163

Schnack-Schiel SB (2003) The macrobiology of sea ice. In: Thomas DN, Dieckmann GS (eds) Sea ice: an introduction to its physics, chemistry, biology and geology. Blackwell, Oxford, pp 211-239

Schnack-Schiel SB, Dieckmann GS, Gradinger R, Melnikov I, Spindler M, Thomas DN (2001) Meiofauna in sea ice of the Weddell Sea (Antarctica). Polar Bioi 24:724-728

Schratzberger M, Ingels J (2017) Meiofauna matters: the roles of meiofauna in benthic ecosystems. J Exp Mar Biol Ecol. https://doi. org/10.1016/j.jembe.2017.01.007

Schratzberger M, Lampadariou N, Somerfield PJ, Vandepitte L, Vanden Berghe E (2009) The impact of seabed disturbance on nematode communities: linking field and laboratory observations. Mar Biol 156:709-724

Schrijvers J, Okondo J, Steyaert M, Vincx M (1995) Influence of epibenthos on meiobenthos of the Ceriops tagal mangrove sediment at Gazi Bay, Kenya. Mar Ecol Prog Ser 128:247-259

Schrijvers J, Schallier R, Silence J, Okondo JP, Vincx M (1997) Interactions between epibenthos and meiobenthos in a high intertidal Avicennia marina mangrove forest. Mangroves Salt Marshes 1: $137-154$

Scott CL, Kwasniewski S, Falk-Petersen S, Sargent JR (2002) Lipids and fatty acids in the copepod Jaschnovia brevis (Jaschnov) and in particulates from Arctic waters. Polar Biol 25:65-71

Seibel BA, Drazen JC (2007) The rate of metabolism in marine animals: environmental constraints, ecological demands and energetic opportunities. Phil Trans R Soc B 362:2061-2078

Sen Gupta BK, Aharon P (1994) Benthic foraminifera of bathyal hydrocarbon vents of the Gulf of Mexico: initial report on communities and stable isotopes. Geo Mar Lett 14:88-96

Sen Gupta BK, Machain-Castillo ML (1993) Benthic foraminifera in oxygen-poor habitats. Mar Micropaleontol 20:183-201

Sen Gupta BK, Platon E, Bernhard JM, Aharon P (1997) Foraminiferal colonization of hydrocarbon-seep bacterial mats and underlying sediment, Gulf of Mexico slope. J Foramin Res 27:292-300 
Sen Gupta BK, Smith LE, Lobegeier MK (2007) Attachment of Foraminifera to vestimentiferan tubeworms at cold seeps: refuge from seafloor hypoxia and sulfide toxicity. Mar Micropaleontol 62:1-6

Sergeeva NG, Zaika VE (2013) The Black Sea meiobenthos in permanently hypoxic habitat. Acta Zool Hung 65:139-150

Sergeeva NG, Gooday A, Mazlumyan SA, Kolesnikova E, Lichtschlag A, Kosheleva TN, Anikeeva OV (2011) Meiobenthos of the oxic/ anoxic interface in the southwestern region of the Black Sea: abundance and taxonomic composition. In: Altenbach AV, Bernhard JM, Seckbach J (eds) Anoxia. Evidence for eukaryote survival and paleontological strategies. Springer, Dordrecht, pp 369-401

Sergeeva NG, Mazlumyan SA, Çagatay N, Lichtschlag A (2013) Hypoxic meiobenthic communities of the Istanbul Strait's (Bosporus) outlet area of the Black Sea. Turk J Fish Aquat Sci 13: $33-41$

Sergeeva NG, Mazlumyan SA, Lichtschlag A, Holtappels M (2014) Benthic protozoa and metazoa living under anoxic and sulfide conditions in the Black Sea: direct observations of actively moving Ciliophora and Nematoda. Int J Mar Sci 4:1-11

Setoguchi Y, Nomaki H, Kitahashi T, Watanabe H, Inoue K, Ogawa NO, Shimanaga M (2014) Nematode community composition in hydrothermal vent and adjacent non-vent fields around Myojin Knoll, a seamount on the Izu-Ogasawara Arc in the western North Pacific Ocean. Mar Biol 161:1775-1785

Shackleton EH (1909) Results of the British Antarctic expedition, 19079. Geogr J 34:481-500

Shepard FP (1972) Submarine canyons. Earth-Sci Rev 8:1-12

Sheridan P (1997) Benthos of adjacent mangrove, seagrass and nonvegetated habitats in Rookery Bay, Florida, U.S.A. Estuar Coastal Shelf Sci 44:455-469

Shimanaga M, Kitazato H, Shirayama Y (2000) Seasonal patterns of vertical distribution between meiofaunal groups in relation to phytodetritus deposition in the bathyal Sagami Bay, central Japan. J Oceanogr 56:379-387

Shirayama Y (1992) Studies of meiofauna collected from the Iheya Ridge during the dive 541 of the "SHINKAI 2000". JAMSTEC Deep Sea Res 8:287-290

Sibuet M, Olu K (1998) Biogeography, biodiversity and fluid dependence of deep-sea cold-seep communities at active and passive margins. Deep Sea Res II Top Stud Oceanogr 45:517-567

Sket B (1996) The ecology of anchihaline caves. Trends Ecol Evol 11: 221-225

Smith PB (1973) Foraminifera of the north Pacific Ocean. Geol Surv Prof Pap 766:1-27, plates 1-4

Smith CR, Baco AR (2003) Ecology of whale falls at the deep-sea floor. Oceanogr Mar Biol 41:311-354

Smith CR, De Leo FC, Bernardino AF, Sweetman AK, Martinez Arbiz P (2008) Abyssal food limitation, ecosystem structure and climate change. Trends Ecol Evol 23:518-528

Snelgrove PVR, Smith CR (2002) A riot of species in an environmental calm: the paradox of the species-rich deep-sea floor. In: Gibson RN, Barnes M, Atkinson RJA (eds) Oceanography and marine biology: an annual review, vol 40. Taylor \& Francis, London, pp 311-342

Soetaert K, Heip C, Vincx M (1991) The meiobenthos along a Mediterranean deep-sea transect off Calvi (Corsica) and in an adjacent canyon. Mar Ecol 12:227-242

Soltwedel T, Hasemann C, Quéric NV, von Juterzenka K (2005) Gradients in activity and biomass of the small benthic biota along a channel system in the deep Western Greenland Sea. Deep Sea Res I Oceanogr Res Pap 52:815-835

Somerfield PJ, Gee JM, Aryuthaka C (1998) Meiofaunal communities in a Malaysian mangrove forest. J Mar Biol Assoc UK 78:717-732

Sommer S, Gutzmann E, Pfannkuche O (2007) Sediments hosting gas hydrates: oases for metazoan meiofauna. Mar Ecol Prog Ser 337: $27-37$
Sørensen MV (2014) First account of echinoderid kinorhynchs from Brazil, with the description of three new species. Mar Biodivers 44:251-274

Sørensen MV, Jørgensen A, Boesgaard TM (2000) A new Echinoderes (Kinorhyncha: Cyclorhagida) from a submarine cave in New South Wales, Australia. Cah Biol Mar 41:167-179

Spindler M, Dieckmann GS, Lange MA (1990) Seasonal and geographic variations in sea ice community structure of the Weddell Sea, Antarctica. In: Kerry KR, Hempel G (eds) Antarctic ecosystems. Ecological change and conservation. Springer, Berlin, pp 129-135

Stock JH (1971) Collocherides astroboae n. gen., n. sp., a siphonostome cyclopoid copepod living in the stomach of basket stars. Bijdragen tot de Dierkunde 41(1):19-22

Sukardjo S (1994) Soils in the mangrove forests of the Apar nature reserve, Tanah Grogot, East Kalimantan, Indonesia. Southeast Asian Stud 32:385-398

Swallow JE, Culver SJ (1999) Living (Rose Bengal stained) benthic foraminifera from New Jersey continental margin canyons. J Foramin Res 29:104-116

Tarasov VG, Gebruk AV, Mironov AN, Moskalev LI (2005) Deep-sea and shallow-water hydrothermal vent communities: two different phenomena? Chem Geol 224:5-39

Tasiemski A, Salzet M (2010) Leech immunity: from brain to peripheral responses. Adv Exp Med Biol 708:80-104

Tasiemski A, Jung S, Boidin-Wichlacz C, Jollivet D, Cuvillier-Hot V, Pradillon F, Vetriani C, Hecht O, Sönnichsen FD, Gelhaus C, Hung CW, Tholey A, Leippe M, Grötzinger J, Gaill F (2014) Characterization and function of the first antibiotic isolated from a vent organism: the extremophile metazoan Alvinella pompejana. PLoS One 9(4):e95737

Tasiemski A, Massol F, Cuvillier-Hot V, Boidin-Wichlacz C, Roger E, Rodet F, Fournier I, Thomas F, Salzet M (2015) Reciprocal immune benefit based on complementary production of antibiotics by the leech Hirudo verbana and its gut symbiont Aeromonas veronii. Sci Rep 5:17498

Tchesunov AV (2015) Free-living nematode species (Nematoda) dwelling in hydrothermal sites of the North Mid-Atlantic Ridge. Helgoland Mar Res 69:343-384

Tchesunov AV, Ingels J, Popova EV (2012) Marine free-living nematodes associated with symbiotic bacteria in deep-sea canyons of north-east Atlantic Ocean. J Mar Biol Assoc UK 92:1257-1271

Thiel H (1975) The size structure of the deep-sea benthos. Int Rev Gesamten Hydrobiol 60:576-606

Thiel H (1979) Structural aspects of the deep-sea benthos. Ambio Spec Rep 6:25-31

Thiermann F, Windoffer R, Giere O (1994) Selected meiofauna around shallow water hydrothermal vents off Milos (Greece): ecological and ultrastructural aspects. Vie Milieu 44:215-226

Thiermann F, Akoumianaki I, Hughes JA, Giere O (1997) Benthic fauna of a shallow-water gaseohydrothermal vent area in the Aegean Sea (Milos, Greece). Mar Biol 128:149-159

Thiermann F, Vismann B, Giere O (2000) Sulphide tolerance of the marine nematode Oncholaimus campylocercoides - a result of internal sulphur formation? Mar Ecol Prog Ser 193:251-259

Thistle D (2001) Harpacticoid copepods are successful in the soft-bottom deep sea. Hydrobiologia 453/454:255-259

Thistle D, Sedlacek L, Carman KR, Barry JP (2017) Influence of habitat heterogeneity on the community structure of deep-sea harpacticoid communities from a canyon and an escarpment site on the continental rise off California. Deep Sea Res I Oceanogr Res Pap 123:56-61

Tietjen JH (1989) Ecology of deep-sea nematodes from the Puerto Rico Trench area and Hatteras Abyssal Plain. Deep Sea Res A Oceanogr Res Pap 36:1579-1594

Todaro MA, Shirley TC (2003) A new meiobenthic priapulid (Priapulida, Tubiluchidae) from a Mediterranean submarine cave. Ital J Zool 70: 79-87 
Todaro MA, Hummon WD, Balsamo M, Fregni E, Tongiorgi P (2001) Inventario dei Gastrotrichi marini italiani: una checklist annotata. Atti Soc Tosc Sci Nat Mem Ser B 107:75-137

Todaro MA, Leasi F, Bizzarri N, Tongiorgi P (2006) Meiofauna densities and gastrotrich community composition in a Mediterranean sea cave. Mar Biol 149:1079-1091

Todo Y, Kitazato H, Hashimoto J, Gooday AJ (2005) Simple foraminifera flourish at the ocean's deepest point. Science 307:689

Torres ME, Mix AC, Kinports K, Haley B, Klinkhammer GP, McManus J, de Angelis MA (2003) Is methane venting at the seafloor recorded by $\delta 13 \mathrm{C}$ of benthic foraminifera shells? Paleoceanography $18(3)$. https://doi.org/10.1029/2002PA000824

Torres ME, Martin RA, Klinkhammer GP, Nesbitt EA (2010) Post depositional alteration of foraminiferal shells in cold seep settings: new insights from flow-through time-resolved analyses of biogenic and inorganic seep carbonates. Earth Planet Sci Lett 299:10-22

Tsuchiya M, Grimm GW, Heinz P, Stögerer K, Ertan KT, Collen J, Brüchert V, Hemleben C, Hemleben V, Kitazato H (2009) Ribosomal DNA shows extremely low genetic divergence in a world-wide distributed, but disjunct and highly adapted marine protozoan (Virgulinella fragilis, Foraminiferida). Mar Micropaleontol 70:8-19

Tsurumi M, de Graaf RC, Tunnicliffe V (2003) Distributional and biological aspects of copepods at hydrothermal vents on the Juan de Fuca Ridge, north-east Pacific Ocean. J Mar Biol Assoc UK 83: 469-477

Tunnicliffe V (1991) The biology of hydrothermal vents: ecology and evolution. Oceanogr Mar Biol Ann Rev 29:319-407

Tyler P, Amaro T, Arzola R, Cunha MR, de Stigter H, Gooday AJ, Huvenne V, Ingels J, Kiriakoulakis K, Lastras G, Masson D, Oliveira A, Pattenden A, Vanreusel A, van Weering T, Vitorino J, Witte U, Wolff G (2009) Europe's grand canyon: Nazaré submarine canyon. Oceanography 22:46-57

United Nations Educational, Scientific and Cultural Organization (UNESCO) (2009) Global open oceans and deep seabed (GOODS). Biogeographic classification. Intergovernmental Oceanographic Commission. IOC Technical Series No. 84. UNESCO-IOC, Paris

Van Colen C, Montserrat F, Verbist K, Vincx M, Steyaert M, Vanaverbeke J, Herman PMJ, Degraer S, Ysebaert T (2009) Tidal flat nematode responses to hypoxia and subsequent macrofauna-mediated alterations of sediment properties. Mar Ecol Prog Ser 381:189-197

Van Dover CL (2000) The ecology of deep-sea hydrothermal vents. Princeton University Press, Princeton, p 352

Van Gaever S, Moodley L, de Beer D, Vanreusel A (2006) Meiobenthos at the Arctic Håkon Mosby Mud Volcano, with a parental-caring nematode thriving in sulphide-rich sediments. Mar Ecol Prog Ser 321:143-155

Van Gaever S, Olu K, Derycke S, Vanreusel A (2009a) Metazoan meiofaunal communities at cold seeps along the Norwegian margin: influence of habitat heterogeneity and evidence for connection with shallow-water habitats. Deep Sea Res I Oceanogr Res Pap 56:772785

Van Gaever S, Galéron J, Sibuet M, Vanreusel A (2009b) Deep-sea habitat heterogeneity influence on meiofaunal communities in the Gulf of Guinea. Deep Sea Res II Top Stud Oceanogr 56:2259-2269

Vanhove S, Wittoeck J, Desmet G, Van den Berghe B, Herman RL, Bak RPM, Nieuwland G, Vosjan JH, Boldrin A, Rabitti S, Vincx M (1995) Deep-sea meiofauna communities in Antarctica: structural analysis and relation with the environment. Mar Ecol Prog Ser 127:65-76

Vanhove S, Lee HJ, Beghyn M, Van Gansbeke D, Brockington S, Vincx M (1998) The metazoan meiofauna in its biogeochemical environment: the case of an Antarctic coastal sediment. J Mar Biol Assoc UK 78:411-434
Vanhove S, Arntz W, Vincx M (1999) Comparative study of the nematode communities on the southeastern Weddell Sea shelf and slope (Antarctica). Mar Ecol Prog Ser 181:237-256

Vanhove S, Beghyn M, Van Gansbeke D, Bullough LW, Vincx M (2000) A seasonally varying biotope at Signy Island, Antarctic: implications for meiofaunal structure. Mar Ecol Prog Ser 202:13-25

Vanhove S, Vermeeren H, Vanreusel A (2004) Meiofauna towards the South Sandwich Trench (750-6300m), focus on nematodes. Deep Sea Res II Top Stud Oceanogr 51:1665-1687

Vanreusel A, Van den Bossche I, Thiermann F (1997) Free-living marine nematodes from hydrothermal sediments: similarities with communities from diverse reduced habitats. Mar Ecol Prog Ser 157:207219

Vanreusel A, Clough L, Jacobsen K, Ambrose W, Jivaluk J, Ryheul V, Herman R, Vincx M (2000) Meiobenthos of the central Arctic Ocean with special emphasis on the nematode community structure. Deep Sea Res I Oceanogr Res Pap 47:1855-1879

Vanreusel A, Andersen AC, Boetius A, Connelly D, Cunha MR, Decker C, Hilario A, Kormas KA, Maignien L, Olu K, Pachiadaki M, Ritt B, Rodrigues C, Sarrazin J, Tyler P, Van Gaever S, Vanneste H (2009) Biodiversity of cold seep ecosystems along the European margins. Oceanography 22:110-127

Vasconcelos DM, dos Santos PJP, Trinidade RLN (2004) Distribuição espacial da meiofauna no estuário do Rio Formoso, Pernambuco, Brasil. Atlântica, Rio Grande 26:45-54

Veit-Köhler G, Gerdes D, Quiroga E, Hebbeln D, Sellanes J (2009) Metazoan meiofauna within the oxygen-minimum zone off Chile: results of the 2001-PUCK expedition. Deep Sea Res II Top Stud Oceanogr 56:1105-1111

Veit-Köhler G, Guilini K, Peeken I, Quillfeldt P, Mayr C (2013) Carbon and nitrogen stable isotope signatures of deep-sea meiofauna follow oceanographical gradients across the Southern Ocean. Prog Oceanogr 110:69-79

Vetter EW, Smith CR, De Leo FC (2010) Hawaiian hotspots: enhanced megafaunal abundance and diversity in submarine canyons on the oceanic islands of Hawaii. Mar Ecol 31:183-199

Vidakovic J, Boucher G (1987) Gutless marine nematodes of the genus Astomonema Ott et al., 1982. Cah Biol Mar 28:111-120

Villora-Moreno S (1996) A new genus and species of the deep-sea family Coronarctidae (Tardigrada) from a submarine cave with a deep-sea like condition. Sarsia 81:277-283

Vopel K, Dehmlow J, Johansson M, Arlt G (1998) Effects of anoxia and sulphide on populations of Cletocamptus confluens (Copepoda, Harpacticoida). Mar Ecol Prog Ser 175:121-128

Vranken G, Vanderhaeghen R, Heip C (1991) Effects of pollutants on life-history parameters of the marine nematode Monhystera disjuncta. ICES J Mar Sci 48:325-334

Walther G-R, Post E, Convey P, Menzel A, Parmesan C, Beebee TJ, Fromentin J-M, Hoegh-Guldberg O, Bairlein F (2002) Ecological responses to recent climate change. Nature 416:389-395

Watling L, Guinotte J, Clark MR, Smith CR (2013) A proposed biogeography of the deep ocean floor. Prog Oceanogr 111:91-112

Wei CL, Rowe GT, Escobar-Briones E, Boetius A, Soltwedel T, Caley MJ, Soliman Y, Huettmann F, Qu F, Yu Z, Pitcher CR, Haedrich RL, Wicksten MK, Rex MA, Baguley JG, Sharma J, Danovaro R, MacDonald IR, Nunnally CC, Deming JW, Montagna P, Lévesque M, Weslawski JM, Wlodarska-Kowalczuk M, Ingole BS, Bett BJ, Billett DSM, Yool A, Bluhm BA, Iken K, Narayanaswamy BE (2010) Global patterns and predictions of seafloor biomass using random forests. PLoS One 5:e15323

Werner I (2006) Seasonal dynamics of sub-ice fauna below pack ice in the Arctic (Fram Strait). Deep Sea Res I Oceanogr Res Pap 53:294-309

Werner I, Martinez Arbizu P (1999) The sub-ice fauna of the Laptev Sea and the adjacent Arctic Ocean in summer 1995. Pol Biol 21:71-79 
Wetzel MA, Fleeger JW, Powers SP (2001) Effects of hypoxia and anoxia on meiofauna: a review with new data from the Gulf of Mexico. Coastal Estuar Stud 58:165-184

Wieser W (1954) Beiträge zur Kenntnis der Nematoden submariner Höhlen. Ergebnisse der österreichischen Tyrrhenia-Expedition 1952, Teil II. Öst Zool Z 5:172-230

Willems WR, Curini-Galletti M, Ferrero TJ, Fontaneto D, Heiner I, Huys R, Ivanenko VN, Kristensen RM, Kånneby T, MacNaughton MO, Martínez Arbizu P, Todaro MA, Sterrer W, Jondelius U (2009) Meiofauna of the Koster-area, results from a workshop at the Sven Lovén Centre for Marine Sciences (Tjärnö, Sweden). Meiofauna Mar 17:1-34

Woodward G (2010) Integrative ecology, volume 43: from molecules to ecosystems. Advances in ecological research. Academic Press, London

Woulds C, Cowie GL, Levin LA, Andersson JH, Middelburg JJ, Vandewiele S, Lamont PA, Larkin KE, Gooday AJ, Schumacher S, Whitcraft C, Jeffreys RM, Schwartz M (2007) Oxygen as a control on sea floor biological communities and their roles in sedimentary carbon cycling. Limnol Oceanogr 52:1698-1709

Yamasaki H (2016) Ryuguderes iejimaensis, a new genus and species of Campyloderidae (Xenosomata: Cyclorhagida: Kinorhyncha) from a submarine cave in the Ryukyu Islands, Japan. Zool Anz 265:69-79

Yamasaki H, Fujimoto S (2014) Two new species in the Echinoderes coulli group (Echinoderidae, Cyclorhagida, Kinorhyncha) from the Ryukyu Islands, Japan. Zookeys 382:27-52

Yamasaki H, Kajihara H (2012) A new brackish-water species of Echinoderes (Kinorhyncha: Cyclorhagida) from the Seto Inland Sea, Japan. Species Diversity 17:109-118

Yancey PH, Gerringer ME, Drazen JC, Rowden AA, Jamieson A (2014) Marine fish may be biochemically constrained from inhabiting the deepest ocean depths. Proc Natl Acad Sci U S A 111:4461-4465

Youssef T, Saenger P (1999) Mangrove zonation in Mobbs BayAustralia. Estuar Coast Shelf Sci 49:43-50

Zasloff M (2002) Antimicrobial peptides of multicellular organisms. Nature 415:389-395

Zekely J, Gollner S, Van Dover CL, Govenar B, Le Bris N, Nemeschkal H, Bright M (2006a) Nematode communities associated with tubeworm and mussel aggregations on the East Pacific Rise. Cah Biol Mar 47:477-482
Zekely J, Sørensen MV, Bright M (2006b) Three new nematode species (Monhysteridae) from deep-sea hydrothermal vents. Meiofauna Mar 15:25-42

Zekely J, Van Dover CL, Nemeschkal HL, Bright M (2006c) Hydrothermal vent meiobenthos associated with mytilid mussel aggregations from the Mid-Atlantic Ridge and the East Pacific Rise. Deep Sea Res I Oceanogr Res Pap 53:1363-1378

Zeppilli D, Danovaro R (2009) Meiofaunal diversity and assemblage structure in a shallow-water hydrothermal vent in the Pacific Ocean. Aquat Biol 5:75-84

Zeppilli D, Mea M, Corinaldesi C, Danovaro R (2011) Mud volcanoes in the Mediterranean Sea are hot spots of exclusive meiobenthic species. Prog Oceanogr 91:260-272

Zeppilli D, Canals M, Danovaro R (2012) Pockmarks enhance deep-sea benthic biodiversity: a case study in the western Mediterranean Sea. Div Distrib 18:832-846

Zeppilli D, Vanreusel A, Pradillon F, Fuchs S, Mandon P, James T, Sarrazin J (2015a) Rapid colonisation by nematodes on organic and inorganic substrata deployed at the deep-sea Lucky Strike hydrothermal vent field (Mid-Atlantic Ridge). Mar Biodivers 45:489504

Zeppilli D, Sarrazin J, Leduc D, Arbizu PM, Fontaneto D, Fontanier C, Gooday AJ, Kristensen RM, Ivanenko VN, Sørensen MV, Vanreusel A, Thébault J, Mea M, Allio N, Andro T, Arvigo A, Castrec J, Danielo M, Foulon V, Fumeron R, Hermabessiere L, Hulot V, James T, Langonne-Augen R, Le Bot T, Long M, Mahabror D, Morel Q, Pantalos M, Pouplard E, Raimondeau L, Rio-Cabello A, Seite S, Traisnel G, Urvoy K, Van Der Stegen T, Weyand M, Fernandes D (2015b) Is the meiofauna a good indicator for climate change and anthropogenic impacts? Mar Biodivers 45:505-535

Zeppilli D, Cueff-Gauchard V, Bellec L, Franzetti B, Decraemer W, Fontaneto D, Fuchs S, Gayet N, Girard E, Jebbar M, Mandon P, Portail M, Sarrazin J, Smol N, Sørensen M, Tasiemski A, Vanreusel A, Wichlacz C, Cambon-Bonavita MA (n.d.) Nematode-prokaryote interactions in deep-sea hydrothermal vents. Sci Rep (submitted)

Zhou H (2001) Effects of leaf litter addition on meiofaunal colonization of azoic sediments in a subtropical mangrove in Hong Kong. J Exp Mar Biol Ecol 256:99-121 